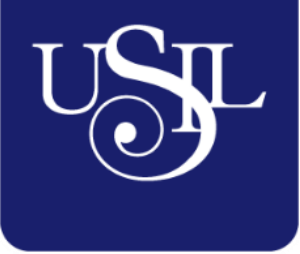

UNIVERSIDAD

SAN IGNACIO

DE LOYOLA

ESCUELA DE POSTGRADO

Maestría en Diseño Gráfico

\title{
APLICACIÓN DE LA NOVELA GRÁFICA INSPIRADA EN LA COMUNIDAD KUKAMA KUKAMIRIA PARA ENRIQUECER EL ACERVO MULTICULTURAL DE ESTUDIANTES DE COMUNICACIÓN
}

Tesis para optar el grado de Maestro en Diseño Gráfico

\section{ROCIO EMILIA VILLACORTA CALDERON}

Asesora:

Mg. Guillermina Victoria Ávalos Carrillo

Lima - Perú

2020 
A mi padre+: Raúl H. Villacorta Vigo

Seguirás navegando por los caminos de la literatura.

$\mathrm{Y}$ a todos los que ya subieron por la liana: mis ancestros, mi herencia.

A mi madre y a los que están aquí e iluminan el camino. 


\section{Agradecimientos}

A Pablo Taricuarima Paima y familia (sus padres don Pablo y doña Rita, la abuela Juana, Rebeca Taricuarima y Alex Aspajo), de Casa Kukama (Santo Tomás, Loreto).

A los pobladores de Padre Cocha y Puerto Prado (Loreto).

Por compartir sus costumbres, historia y saberes.

A Vicky Ávalos, Sandra Tineo y Rafael Vivanco, mis guías en este proyecto, por sus recomendaciones, paciencia y contactos.

Y a Andrea Cruzado, Pedro Horna, Jacqueline Sánchez y Sebastián Lino, exalumnos y alumno de la Universidad de Lima, por su incondicional apoyo. 


\section{Tabla de contenidos}

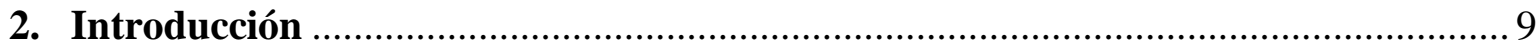

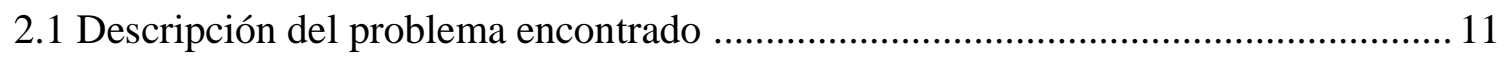

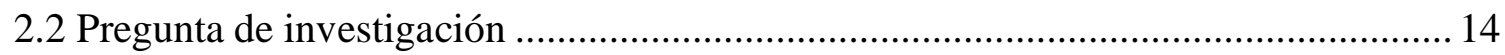

2.3 Justificación de la investigación desde el punto de vista personal ............................ 14

2.4 Problema principal (formulado en pregunta con variables) .................................... 15

2.5 Problemas secundarios (formulado en pregunta con variables) .................................. 15

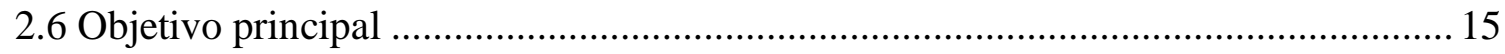

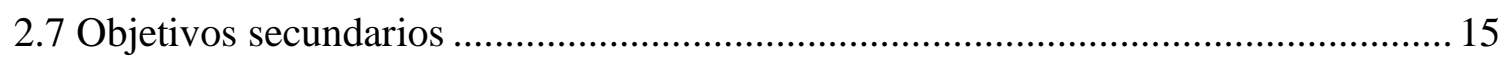

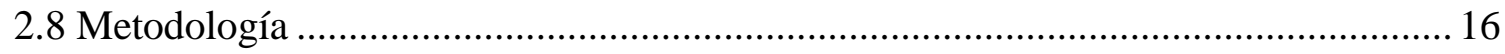

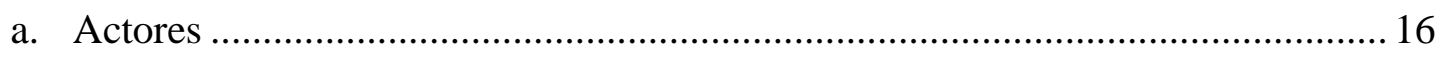

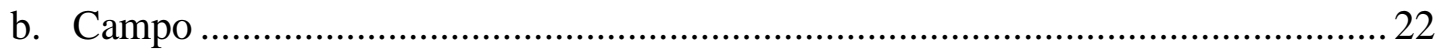

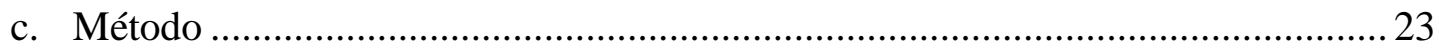

\section{CAPÍTUlO I}

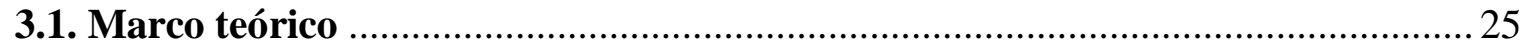

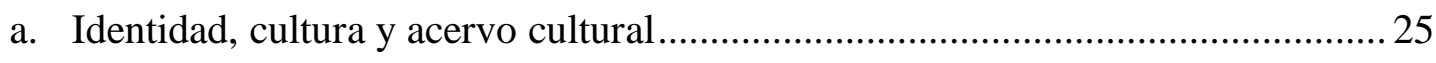

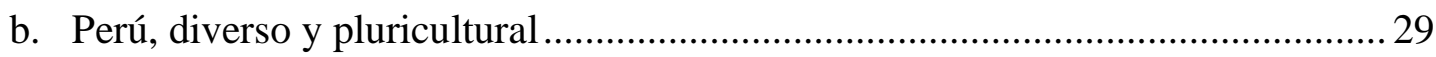

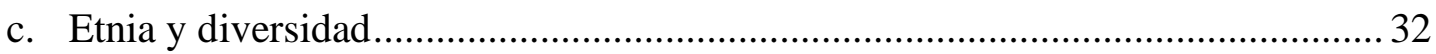

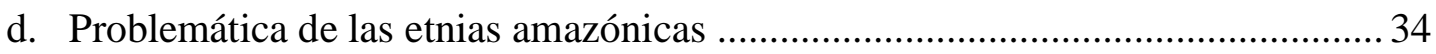

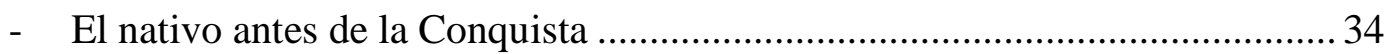

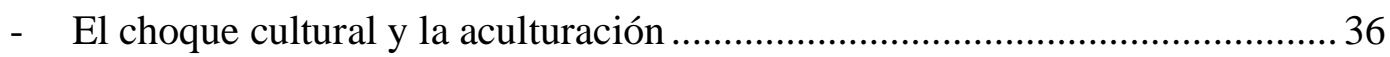

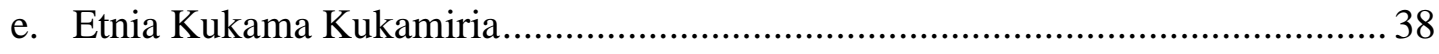

- Historia de los Kukama Kukamiria ................................................................. 41

- Sobre el mito y la cosmovisión Kukama.......................................................42

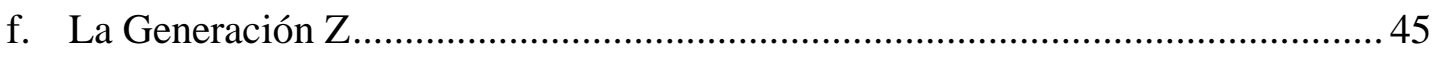

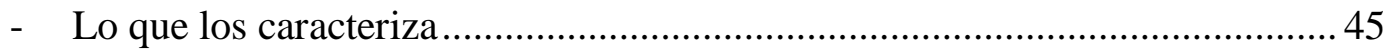

- Jóvenes y conocimiento de la selva amazónica............................................... 47

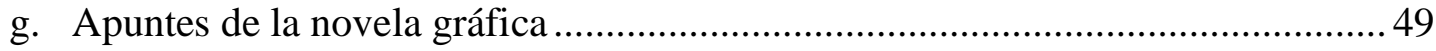

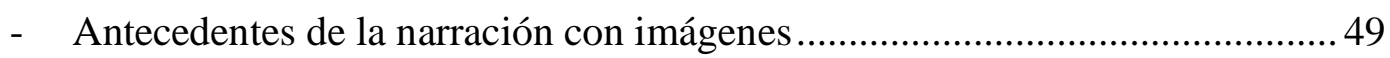

- ¿Cómic o novela gráfica? Cuestión de nombre ..................................................54

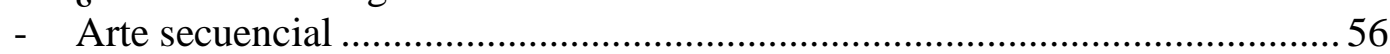

- Exponentes internacionales de la novela gráfica.........................................57

- La narrativa gráfica en Perú ...........................................................................6 64

- Aporte educativo de la narración gráfica …................................................... 70

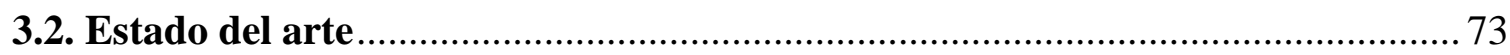




\section{CAPÍtULLO II}

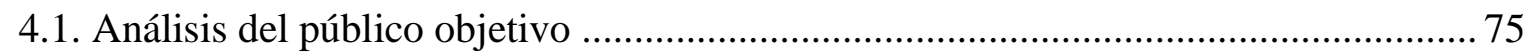

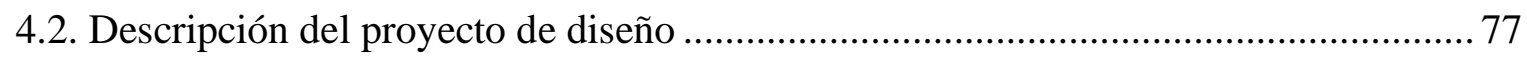

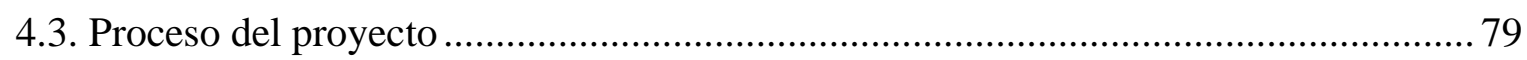

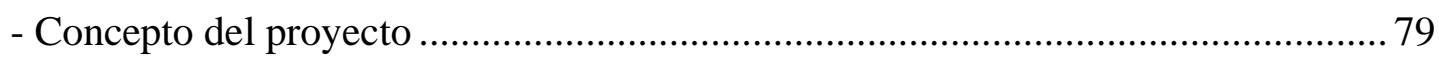

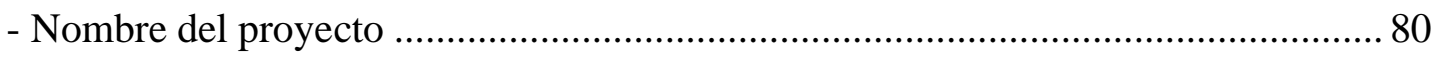

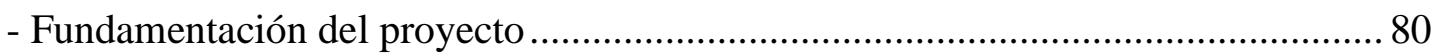

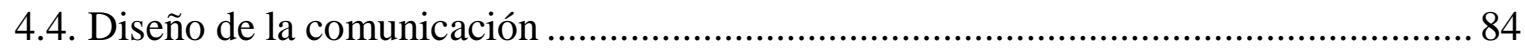

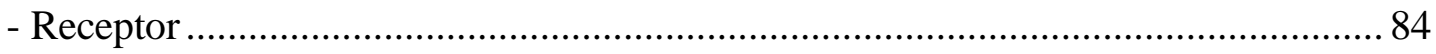

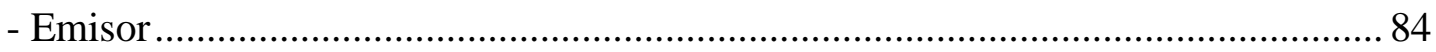

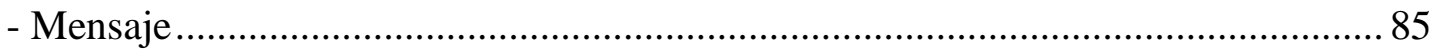

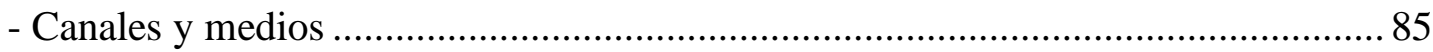

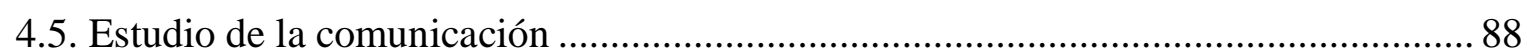

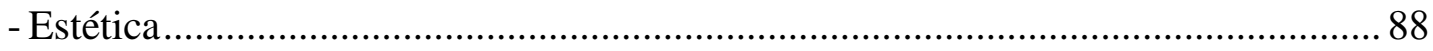

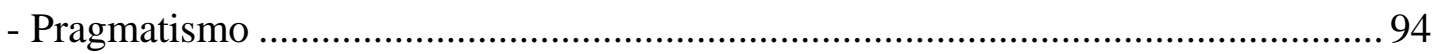

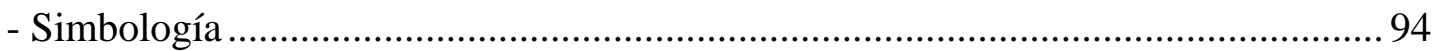

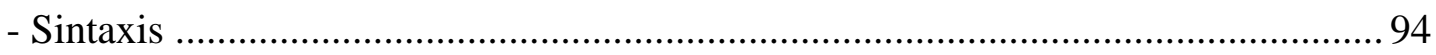

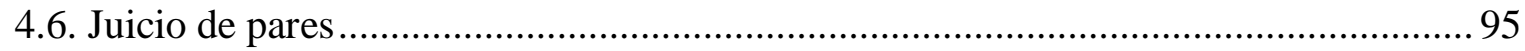

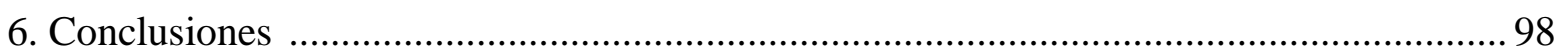

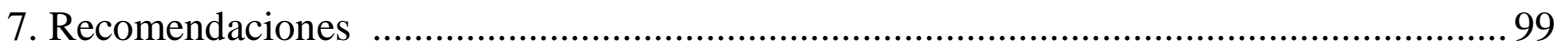

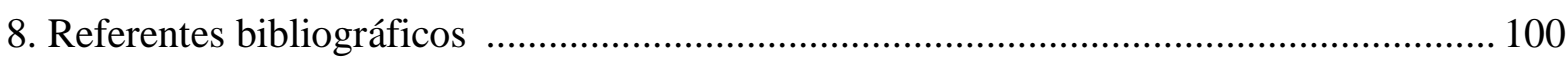

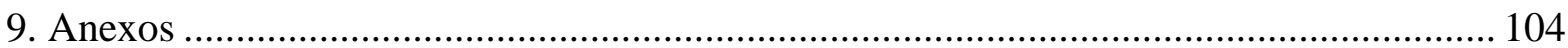

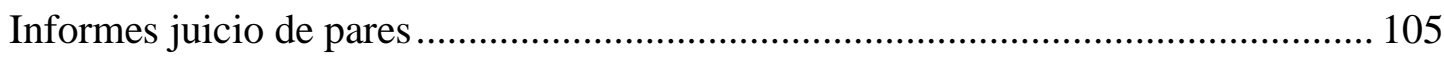

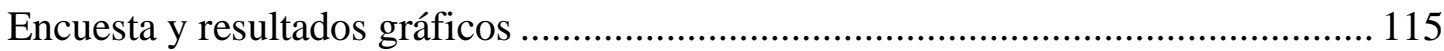

Entrevista Sonaly Tuesta Altamirano ............................................................ 122

Entrevista Carlos Rivadeneyra Olcese .............................................................. 128 


\section{Lista de cuadros}

Cuadro 1. Metodología de estudio. 19

\section{Lista de figuras}

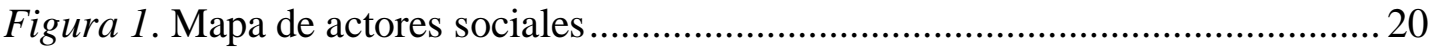

Figura 2. Ubicación de las comunidades Kukama Kukamiria ................................. 22

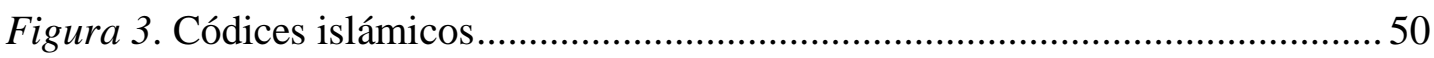

Figura 4. Imagen maya del Códice de Dresde..........................................................50

Figura 5. Detalle de la Columna de Trajano...........................................................52

Figura 6. Detalle de la Columna de Marco Aurelio ....................................................5 53

Figura 7. Portada de The Spirit de Will Eisner.......................................................5 57

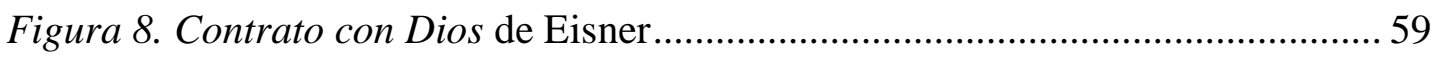

Figura 9. Marea Roja de Steranko .......................................................................... 59

Figura 10. Portada y detalle de interiores de Maus ..................................................6 60

Figura 11. Portada y detalle de interiores de Persépolis ...........................................61

Figura 12. Portada y detalle de interiores de Arrugas ...............................................62

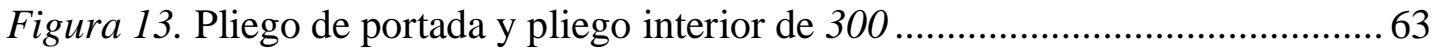

Figura 14. Portada e ilustración interior de Ich Naturaleza Salvaje ..........................64 64

Figura 15. Detalles de interiores de recopilación de Selva misteriosa ......................67 67

Figura 16. Portada y detalle de interiores de Ciudad de payasos..............................6 69

Figura 17. Portada y detalle de interiores de Ayar. La leyenda de los Inkas ............. 70

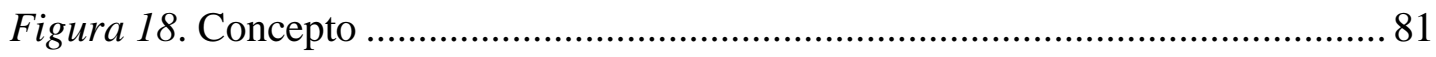

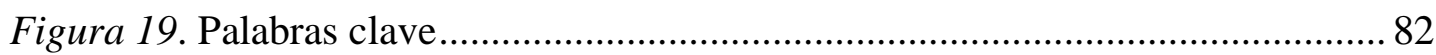

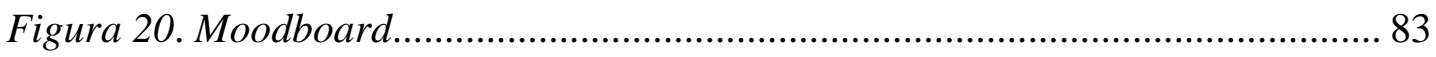

Figura 21. Características generales de la Generación Z ........................................ 86

Figura 22. Características del público objetivo específico: Estudiantes universitarios de comunicación de la Universidad de Lima ................... 87

Figura 23. Portada y detalle de interiores de El hechicero....................................... 88

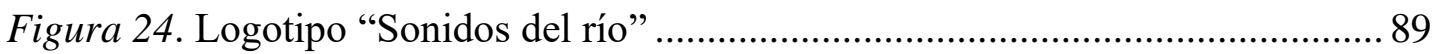

Figura 25. Paleta de colores final ........................................................................ 90

Figura 26. Tipografías para logotipo de "Sonidos del río" y El hechicero................ 91

Figura 27. Tipografías de interiores aplicadas ........................................................ 91

Figura 28. Caracterización de El Esperado ........................................................... 92

Figura 29. Caracterización de el Chamán.............................................................. 93 


\section{Resumen}

El presente proyecto propone una solución de diseño para la problemática del desconocimiento de la realidad(es) de la Selva amazónica; un lugar poco conocido, visto solo con miras turísticas por gran parte de la población peruana. Este desconocimiento influye en el acervo cultural, que se ve disminuido sin esa riqueza y saber milenario, distinto, pero igualmente valioso, que los habitantes de la Amazonía han desarrollado en concordancia con su estilo de vida y hábitat. Se eligió como público objetivo a jóvenes estudiantes de Ciencias de la Comunicación, como futuros agentes de cambio; para trabajar con un campo de acción específico, se optó por la Universidad de Lima.

La solución de diseño propuesta es la novela gráfica: El hechicero, de naturaleza digital, ambientada en una comunidad Kukama Kukamiria, una de las etnias con mayor número de habitantes en toda la Selva amazónica, la cual ha sufrido en gran medida la incomprensión y el rechazo a prácticas culturales durante el proceso de mestizaje, por los que las escondieron e incluso se avergonzaron y que desde la década de los 80 s ha comenzado el largo proceso de reconocimiento y autoaceptación de su cultura. Basada en la novela literaria El misionero y la mujer del hechicero, esta obra es de naturaleza ficticia, inspirada en hechos reales, y respeta las creencias, mitos, y en general, las cosmovisiones de la Amazonía.

Descubrir para valorar es el concepto que guía esta solución gráfica. Lo que no se conocer no se aprecia, por eso es necesario la difusión de otras miradas al mundo en el marco de la pluriculturalidad que caracteriza al Perú.

Palabras clave: Amazonía. Acervo cultural. Cosmovisión. Etnia. Identidad cultural. Kukama Kukamiria. Leyendas. Mitos. Selva. 


\begin{abstract}
This project proposes a design solution to the problems of reality (s) unawareness of the Amazon rainforest; a little-known place, seen just from the tourism perspective by most part of the Peruvian population. This unawareness influences the cultural heritage, which is diminished without that richness and millennial knowledge, different, but likewise valuable, that inhabitants of Amazon have developed in correspondence with its life style and habitat. Young students of Communications Sciences were chosen as target audience, as future change agents; to work in a specific field of action, the Universidad de Lima was chosen.
\end{abstract}

The design solution proposed is the graphic novel: El hechicero, in digital format. Set in a Kukama Kukamiria community, one of the most populated ethnic groups in the whole Amazon rainforest, which have suffered, at a great extent, the incomprehension and reject to cultural practices during the miscegenation process. As a result they were hidden and, even, they felt ashamed and from the 80's they have started a long process of recognition and self acceptance of their culture. Based in the literary novel El misionero y la mujer del hechicero, this work is of fictitious nature, inspired in real facts, and respect of beliefs, myths, and in general, the Amazon world view.

Descubrir para valorar (Discover to value) is the concept leading this graphic solution. What is unknown is not valued, thus, it is necessary the dissemination of other views considering the framework of multi cultures that characterizes Peru.

Key Words: Amazonia. Cultural heritage. World view. Ethnic group. Cultural identity. Kukama Kukamiria. Legends. Myths. Rain forest. 


\section{Introducción}

La investigación se planteó con el objetivo de comprender cómo el desconocimiento de la cosmovisión de una cultura amazónica empobrece el acervo cultural de estudiantes de comunicación, quienes serán los futuros gestores en el proceso de difusión de material informativo o en el planteamiento de estrategias de comunicación. Se consideró la posibilidad que este desconocimiento generase la exotización y estigmatización de una cultura, al imaginarse a los individuos que la conforman de una manera no diferenciada de otros similares y sin considerar sus particularidades; y a la vez presentarlos como personajes exóticos y plenos de curiosidades. Por lo que luego de la investigación se propondrá una solución de diseño para esta problemática.

Se observó lo difícil que resulta entender algunas prácticas y creencias de las etnias amazónicas, que muchas veces se consideran producto de la ignorancia, sin respetar la sabiduría milenaria que conllevan. Asimismo, tampoco se toma en cuenta las diferencias culturales: "No se confunda: los agricultores, ganaderos y otros que viven en forma rústica en la selva viven de acuerdo con su idiosincrasia”. (Piazzini, 2000, p.131.). Esto es consecuencia de, por un lado, el difícil acceso a la zona (por tiempo o recursos); pero más aún, por las grandes diferencias existentes respecto a las tradiciones y creencias occidentales. En un determinado momento se llegó a considerar al indígena como "subdesarrollado" por su cosmovisión y estilo de vida.

Esta visión limitada del mundo indígena, unido a intereses de diversa índole, ha llevado a estas poblaciones a problemáticas muy grandes, como el luchar por sus tierras; el indígena llegó a ser visto como un "freno para el desarrollo" porque ocupan tierras que desde el punto de vista de algunos sectores no producen ni se aprovechan. Actualmente la normatividad jurídica presenta reglas que apoyan los derechos de los pueblos indígena en diferentes 
ámbitos, incluidos su territorio y el uso de los recursos naturales para su autoabastecimiento, la problemática aún continúa: "En el Perú, los derechos de los Pueblos Indígenas se encuentran protegidos normativamente; no obstante, existe una deuda histórica del Estado respecto de su cumplimiento.” (Derecho, Ambiente y Recursos Naturales - DAR, 2018, p.7).

Así, muchas comunidades de la etnia Kukama Kukamiria no han logrado el reconocimiento legal de sus tierras pues estas zonas, donde han vivido desde tiempos inmemoriales, fueron declaradas zonas protegidas de la Reserva Nacional Pacaya-Samiria).

Si la Amazonía genera tanta controversia es por su gran importancia para el Perú. Al ser "una inmensa red de territorios y ríos que ocupan más del 50\% del territorio nacional" (Piazzini, 2000, p.143), se constituye en una gran fuente de riqueza en flora, fauna y recursos minerales, entre otros. Lo cual se complejiza porque a nivel humano, como ya se señaló, es un lugar donde conviven distintas culturas y saberes milenarios. Por eso, es necesario establecer mecanismos para la difusión y la aceptación de la diversidad, con miras a lograr la tolerancia, pilar del éxito de cualquier acción para el desarrollo. Lo cual implica lidiar con obstáculos como las grandes distancias entre las ciudades, la hostilidad del terreno (con muchos ríos, algunos navegables y otros no, cochas y lagos) y el desarrollo de actividades ilícitas con intereses particulares, como la minería ilegal, la tala indiscriminada, el lavado de dinero o el negocio del narcotráfico.

Pero se debe hacer el esfuerzo, porque difundir y lograr que se acepte una herencia pluricultural redundará en el desarrollo nacional y en la construcción de un concepto de identidad más sólido. Al respecto, cabe señalar que la Organización de las Naciones Unidas para la Educación, la Ciencia y la Cultura (UNESCO) rescata el rol de la cultura en la calidad de vida y el bienestar: "Las prácticas culturales, el patrimonio y las expresiones son vehículos fundamentales para la creación, transmisión y reinterpretación de los valores, actitudes y 
convicciones a través de los cuales los individuos y las comunidades transmiten el significado que le dan a sus vidas y su propio desarrollo" (UNESCO, 2013).

Mucho camino ha sido recorrido en pro de este objetivo. A diferencia de hace algunos años, en los que algunos indígenas sentían vergüenza de su procedencia o estilo de vida, hoy en día muchos sí valoran sus características intrínsecas. Tal es el caso de la comunidad Kukama Kukamiria, que desde hace algunos años lucha porque su lengua no muera: "Para el Ministerio de Educación (2013), la lengua [Kukama Kukamiria] se encuentra en serio peligro porque es hablada por generaciones adultas; sin embargo, existen cada vez más iniciativas de sus hablantes por revertir este proceso a través de su enseñanza a niños y niñas. Actualmente, su alfabeto ha sido aprobado recientemente en un congreso con representantes del pueblo y su resolución directoral se encuentra en proceso por el Ministerio de Educación. Asimismo, el pueblo cuenta con siete traductores e intérpretes registrados por el Ministerio de Cultura". (BDP, s/f).

Por otro lado, cabe resaltar la importancia de una confluencia de saberes. No solo gana la herencia cultural que está en el lado de la cultura occidental y tiene la oportunidad de conocer culturas distintas. Sino también las etnias indígenas se enriquecen con el conocimiento del otro. La idea es que en ese proceso se enriquezcan y no se empobrezcan culturalmente.

\subsection{Descripción del problema encontrado}

A pesar de que la selva amazónica se extiende por el $40 \%$ de nueve países sudamericanos, sigue siendo un lugar lleno de misterio, tanto por sus mitos y leyendas, que forman parte de su cosmovisión y constituyen una manera diferente de "apreciar el mundo, de entender la vida y el ser humano" (Rodríguez, 2017, p.13), como por las dificultades geográficas que hacen muy difícil el acceso. Comparten el territorio selvático Perú, Brasil, 
Bolivia, Venezuela, Ecuador, Guayana Francesa, Guayana y Surinam. Aunque no es fácil llegar a la Selva ni vivir en ella, por lo agreste del territorio, fue habitada durante desde hace 3000 años por poblaciones indígenas diversas.

Por su inmenso potencial económico (petróleo, gas, minerales, madera, flora y fauna, e incluso colorantes, entre otros), la Amazonía ha sido una zona muy afectada desde la conquista. Actualmente sufre las consecuencias de diferentes factores, como la deforestación, la minería ilegal, la contaminación de las aguas y el narcotráfico. Resultan perjudicados sus pobladores nativos, muchos de los cuales fueron exterminados en las sangrientas luchas que se han dado en este extenso territorio, sea por su dominio por parte de los grupos hegemónicos (antes, los colonizadores, hoy, el sector empresarial avalado por las políticas estatales); muchos nativos se han visto obligados a migrar a Lima, viéndose en la necesidad de adaptarse a un estilo de vida incluso contrario a su manera de entender el mundo.

Uno de los problemas más importantes que afronta la Amazonía es el poco interés hacia las costumbres y sabiduría de los habitantes de las diversas etnias amazónicas, lo cual es producto del desconocimiento por parte de otros grupos de peruanos. Conocer a plenitud la Amazonía siempre ha sido difícil no solo por sus características geográficas sino también por su diversidad cultural. Son aproximadamente 400 grupos humanos los que la habitan. "No se puede ignorar este "pluralismo" étnico cultural si se pretende tener una visión realista de la Amazonía...” (citado por San Román, 1994, p. 17).

¿Pero, cuál es la mirada que muchos tienen aún ahora, 500 años después, de los grupos humanos que aún sobreviven? Que todos son iguales y que no hay diferencias culturales entre uno y otro.

Muy pocos comprenden las distinciones entre estas etnias, y este pluralismo étnico suele pasar desapercibido. Desde la época de la conquista se homogeneiza a los grupos humanos indígenas, como si no existiesen diferencias culturales entre uno y otro; antes de la 
llegada de los españoles algunos incluso eran enemigos. (San Román, 1994, p. 27). Muchos de ellos tienen similitudes en el estilo de vida, pero a la vez diferencias radicales que pueden comprenderse si se tiene en cuenta, entre otros factores, el entorno en el que estas culturas se han desarrollado: era (y es) difícil en un entorno tan complejo como la Selva Amazónica establecer sociedades con muchos integrantes.

Así, los contrastes entre los pobladores de la Amazonía subsistieron a lo largo del tiempo, aun cuando durante el proceso de colonización hayan sido obligados a vivir y a trabajar en las mismas comunidades; sin embargo, generalmente un nativo de una tribu específica se reconoce como tal y mantiene sus raíces y costumbres.

¿Por qué es importante promover el conocimiento de las cosmovisiones de la Amazonía y el respeto por sus saberes? Ante todo, porque el ser humano debe ser libre de elegir en qué creer y cómo vivir; el Banco Interamericano de Desarrollo (BID) denomina este concepto como "libertad cultural” (BID, 2004); además, los nativos selváticos vivieron años en armonía con la naturaleza y poseen valiosos conocimientos, muchas veces no tomados en cuenta, sobre el uso y conservación de la flora y fauna silvestre.

Para definir un campo de estudio se ha considerado centrar la investigación en la etnia Kukama Kukamiria, quienes según Rivas "han ido experimentando cambios como la pérdida de su lengua y el temor a identificarse como indígenas, aunque en los últimos años esta situación estaría cambiando a raíz de su vinculación con diversas organizaciones que promueven el desarrollo de las comunidades amazónicas. Los Kukama Kukamiria del Bajo Huallaga se habrían autodefinido por primera vez como "indígenas" en el año 1980, a través de la Federación de Comunidades Cocamilla -FEDECOCA" (Rivas 2004, citado en línea). Se ha seleccionado este grupo humano para la investigación por ser uno de los menos conocidos de las etnias amazónicas, cuya realidad y cosmovisión requiere de difusión para la concientización social y crecimiento del acervo cultural del peruano. 
Asimismo, para delimitar el actor “estudiante de comunicación” se coordinó con la Facultad de Comunicación de la Universidad de Lima.

\subsection{Pregunta de investigación}

¿Por qué se infravalora el estilo de vida de los habitantes de la Selva amazónica? En muchos sectores el estilo de vida en la Amazonía es sinónimo de anti-progreso e ignorancia. El hecho de no conocer y por lo tanto no entender mitos, leyendas y tradiciones que implican la creencia en seres irreales que habitan en las aguas o en los bosques, el preferir curarse con yerbas o el hecho de que los chamanes utilicen el Ayahuasca para conectarse con mundos mágicos y recibir ayuda para curar u obtener poder son vistos de manera anecdótica y peyorativa, o utilizados para estereotipar a los habitantes de la Selva con fines turísticos y de promoción.

\subsection{Justificación de la investigación desde el punto de vista personal}

Mi interés en la temática parte de mis orígenes; he nacido en Iquitos, aunque crecí en Lima. Si bien mi primer acercamiento al problema fue por una estricta motivación personal y familiar, he descubierto en la búsqueda realizada diversos aspectos sobre parte de mi herencia cultural. Esto me llevó a pensar: si yo, que nací allá, he estado alejada sobre estos modos de entender el mundo ¿cómo estarán los otros?

La presente investigación pone en evidencia el desconocimiento de las cosmovisiones existentes en la selva peruana y el proyecto propuesto busca contribuir en mejorar la formación integral de los estudiantes universitarios de Ciencias de la Comunicación, acercándolos a una parte de las cosmovisiones de la selva a través de la narrativa visual de una novela gráfica. Para eso, de entre las diversas etnias se trabajó con la comunidad Kukama Kukamiria, para centrar la investigación en un campo específico. 


\subsection{Problema principal}

El empobrecimiento del acervo multicultural de los estudiantes de comunicación de universidades particulares (NSE A, B) por el desconocimiento de la cosmovisión de etnias y culturas amazónicas como los Kukama Kukamiria.

\subsection{Problemas secundarios (formulado en pregunta con variables)}

La ignorancia sobre mitos, costumbres y tradiciones generado por el empobrecimiento del acervo multicultural de los estudiantes de comunicación de universidades particulares (NSE A, B) por el desconocimiento de la cosmovisión de etnias y culturas amazónicas como los Kukama Kukamiria.

La incomprensión del pluralismo étnico cultural de la Amazonía Peruana debido al empobrecimiento del acervo multicultural de los estudiantes de comunicación de universidades particulares (NSE A, B) por el desconocimiento de la cosmovisión de etnias y culturas amazónicas como los Kukama Kukamiria.

\subsection{Objetivo principal}

Explorar el empobrecimiento del acervo multicultural de los estudiantes de comunicación de universidades particulares (NSE A, B) por el desconocimiento de la cosmovisión de etnias y culturas amazónicas como los Kukama Kukamiria.

\subsection{Objetivos secundarios}

Explicar la ignorancia sobre mitos, costumbres y tradiciones generada por el empobrecimiento del acervo multicultural de los estudiantes de comunicación de universidades particulares (NSE A, B) debido al desconocimiento de la cosmovisión de etnias y culturas amazónicas como los Kukama Kukamiria. 
Determinar la incomprensión del pluralismo étnico cultural de la Amazonía Peruana debido al empobrecimiento del acervo multicultural de los estudiantes de comunicación de universidades particulares (NSE A, B) por el desconocimiento de la cosmovisión de etnias y culturas amazónicas como los Kukama Kukamiria.

\subsection{Metodología}

Se precisa una investigación interdisciplinar porque el proyecto implica comprender procesos socioculturales, económicos, pedagógicos y políticas de desarrollo, entre otros. En ese sentido se aplicaría la investigación desde el diseño, pues en el input es necesario analizar el contexto, interactuar con disciplinas como la antropología, la sociología y la comunicación intercultural; para posteriormente, en el output, poder aportar una solución desde el diseño.

La recolección de datos es la primera parte del proceso de diseño, que implica un trabajo colaborativo y la investigación multidisciplinaria. (Ver Cuadro 1).

\section{a. Actores}

Los actores involucrados en la presente investigación se han dividido en 4 grupos: Educación, Estudiantes, Comunidades e Instituciones, lo que puede observarse en el Mapa de Actores Sociales (Ver cuadro 2); cada uno de ellos presenta una serie de actores que se relacionan entre sí. Se describirán los que se han considerado más importantes para la investigación.

Ministerio de Comercio Exterior y Turismo: Según la página web del gobierno del Perú define, dirige, ejecuta, coordina y supervisa la política de comercio exterior y turismo en el país como órgano rector del sector. Regula al actor Promperú. 
En la revisión del web site se encontró que en el presente año Mincetur está ejecutando un plan de acción con miras a fortalecer el turismo comunitario, realizando talleres participativos con los pobladores de diversas regiones tanto de la sierra como de la selva peruana (Amazonas y San Martín, en este último caso), con el objetivo de “...generar procesos de diálogo y sinergias entre los emprendedores y gestores con el objetivo de fortalecer los lineamientos e identidad de Turismo Comunitario" (Mincetur, 2019). El objetivo es el desarrollo sostenible de las poblaciones a través del turismo comunitario.

Promperú: Organismo que tiene como misión "posicionar al Perú en el mundo a través de la promoción de su imagen, sus destinos turísticos y sus productos de exportación con valor agregado, contribuyendo al desarrollo sostenible y descentralizado del país”. Regulado por el Ministerio de Comercio Exterior y Turismo, regula a su vez al actor Agencias de Turismo, que se vincula con el actor "Estudiantes de Comunicación".

Se hizo una búsqueda rápida de comunidades en el buscador de la página web de esta institución, al tipear "Shipibo" aparecieron ocho links, los "Bora" dieron como resultado dos links, mientras que al tipear la palabra "Kukama" solo dio un link. Lo que demuestra la importancia que le da esta institución a la promoción de esta cultura, quizá no considerada como un atractivo turístico.

\section{Asociación Interétnica de Desarrollo de la Selva Peruana (AIDESEP):}

representa a los pueblos indígenas de la Amazonía peruana, generando alternativas de desarrollo con respeto hacia su cosmovisión y estilo de vida. En permanente contacto 
con el actor "Comunidad Kukama Kukamiria". Se autodenominan los voceros de las distintas comunidades amazónicas.

La institución agrupa a 64 pueblos indígenas amazónicos del Perú: Achuar, Amahuaca, Arabela, Asháninka, Ashéninka, Awajun, Bora, Capanahua, Cashinahua, Chamicuro, Ese Eja, Harakbut, Iñapari, Iquitu, Isconahua, Kakataibo, Kakinte, Kandozi-Chapra, Kukama Kukamiria, Madija, Maijuna, Matsigenka, Matses, Muniche, Murui-Muinani, Nomatsigenga, Ocaina, Omagua, Resigaro, Secoya, Sharanahua, Shawi, Shipibo-Konibo, Shiwilu, Taushiro, Tikuna, Urarina, Wampis, Yagua, Yaminahua, Yanesha, Yine, Yora (Nahua), Mashco Piro, Chitonahua y Mastanahua. La lista no contempla 64 nombres, pero cabe señalar que algunos de ellos están repartidos en diferentes zonas, como los Shipibo-Konibo, que se encuentran en Huánuco, Loreto y Madre de Dios, o los Kukama Kukamiria, que viven en Loreto y Ucayali.

AIDESEP cuenta con 109 federaciones para representar a 1,809 comunidades donde viven más de 650,000 hombres y mujeres indígenas agrupados en 19 familias lingüísticas. Dos de estas federaciones son la Asociación de Comunidades Nativas Kukama Kukamiria del Distrito de Urarinas (ACONAKKU) y la Federación de los Pueblos Cocamas Unidos del Marañón (FEDEPCUM).

La organización es liderada por un Consejo Directivo Nacional elegido periódicamente cada 3 años por sus bases: 9 organizaciones regionales descentralizadas, ubicadas en el norte, centro y sur de la Selva peruana. Las federaciones también participan en las elecciones a través de los Congresos Nacionales. 


\begin{tabular}{|c|c|c|}
\hline $\begin{array}{l}\text { - Miembros Kukama Kukamiria. } \\
\text { - AIDESEP. } \\
\text { - CAAAP. } \\
\text { - Ministerio de Transporte y Turismo. } \\
\text { - Promperú. } \\
\text { - Facultad de Comunicación. }\end{array}$ & $\begin{array}{l}\text { - Loreto, c } \\
\text { Kukamiri } \\
\text { Cocha y } \\
\text { - Loreto, ci } \\
\text { - Centro C } \\
\text { - Sede de } \\
\text { - Universic }\end{array}$ & $\begin{array}{l}\text { unidades Kukama } \\
\text { e Santo Tomás, Pa } \\
\text { erto Prado. } \\
\text { ad de Nauta. } \\
\text { ural José Pio Aza } \\
\text { AP. } \\
\text { de Lima. }\end{array}$ \\
\hline ACTORES & & CAMPO \\
\hline \multicolumn{3}{|c|}{ Herramientas } \\
\hline & \multicolumn{2}{|c|}{ Recolección de información } \\
\hline $\begin{array}{c}\text { Recolección } \\
\text { de imágenes } \\
\text { y relatos }\end{array}$ & Entrevistas & Observación \\
\hline
\end{tabular}

Cuadro 1. Metodología de estudio. Fuente: Elaboración propia. 


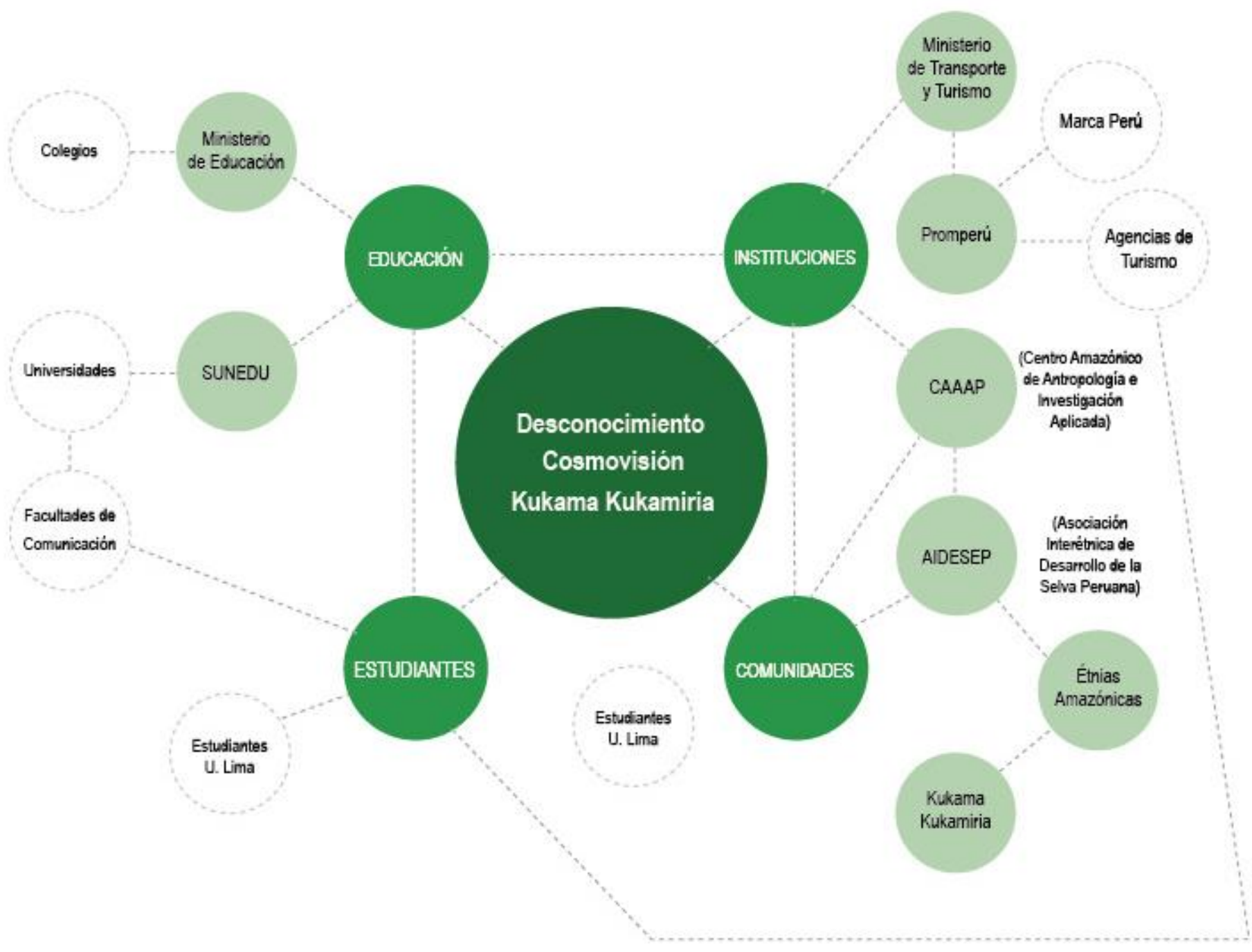

Figura 1. Mapa de actores sociales. Fuente: Elaboración propia. 
Centro Amazónico de Antropología e Investigación Aplicada (CAAAP): Asociación civil sin fines de lucro, institución de la Iglesia católica que trabaja en beneficio de los pueblos indígenas de la Amazonía. Desarrolla actividades para las siguientes familias lingüísticas: Awajún, Asháninka, Mai Huna, Kechwa-Lamistas, Shipibo-Konibo, Yagua y el actor Kukama Kukamiria. Tienen sede en Lima.

Miembros de las comunidades Kukama Kukamiria: pueblos de la familia lingüística Tupí-guaraní, con una población aproximada de 40,000 habitantes. Son esencialmente pesqueros, habitan en las orillas de los ríos Nanay, Ucayali, Marañón y el Amazonas, además de encontrarse algunos caseríos cerca de Pucallpa (en San Pablo de Tushmo), los alrededores de Iquitos (en el poblado de Santo Tomás, Rumococha y Santa Clara), cerca de la frontera de Colombia, por el río Putumayo y en Nauta, que fue fundada en 1830, por el líder cocama Manuel Pacaya Irarica. Promperú los señala como “pueblo alfarero". (Ver mapa en Figura 2).

Denominados antes Cocama-Cocamilla, a los Kukama Kukamiria se les considera actualmente como un solo pueblo, aunque en sus orígenes eran dos grupos. Según el padre Lucas Espinoza es posible que la palabra cocama signifique "gente de fuerza" o "gente de allá". Y cocamilla, quienes eran vecinos de los Cocama, significaría “cocama de corazón” o “cocama legítimo” (AIDESEP, Fundación Telefónica y Programa de Formación de Maestros Bilingües, 2000, p. 162).

Estudiantes de Ciencias de la Comunicación: jóvenes de aproximadamente 17 a 20 años, de la Universidad de Lima. Sus características serán tratadas en detalle en el capítulo II. 


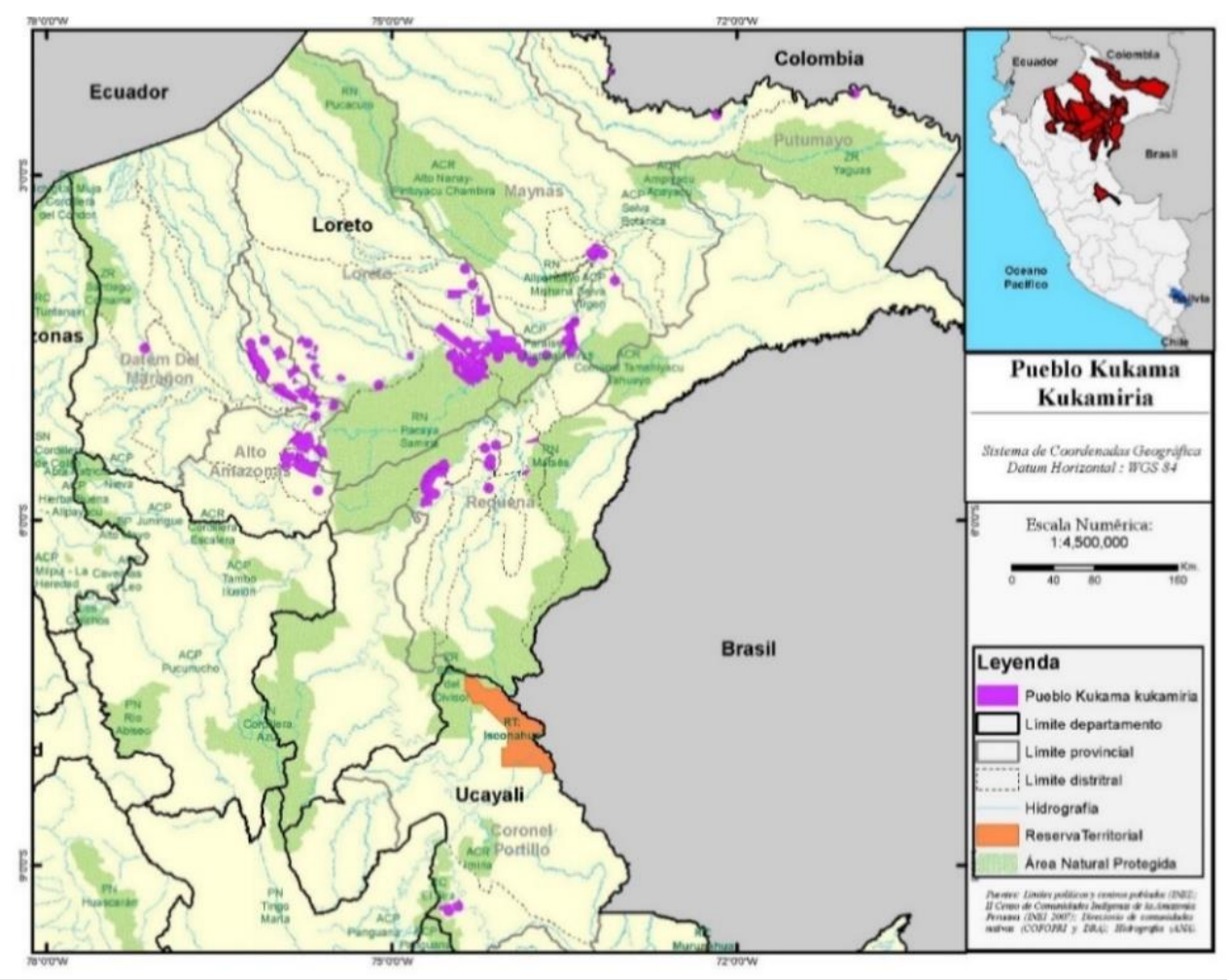

Figura 2: Ubicación de las comunidades Kukama Kukamiria.

Fuente: http://repositorio.ana.gob.pe/

\section{b. Campo}

Loreto, comunidad Kukama Kukamiria: se estableció contacto gracias a Pablo Taricuarima Paima, kukama de nacimiento y propulsor de su cultura a través del ecolodge Casa Kukama ubicado en Santo Tomás, Iquitos, del cual es propietario. Taricuarima promueve talleres sobre las diversas habilidades de los pobladores de la zona. Estudió en la Escuela de Bellas Artes y residió en Lima hasta principios del 2020. Actualmente vive en Santo Tomás.

Se visitaron los centros poblados de Santo Tomás y Padre Cocha, la comunidad de Puerto Prado y la ciudad de Nauta.

Universidad de Lima: es una institución privada sin fines de lucro. Este centro de estudios inició sus actividades en 1962 y entre sus Facultades se encuentra la de 
Comunicación, fundada en 1972 y la primera en este rubro creada en el país. Esta carrera contempla una formación integral del comunicador, con una malla flexible, que se detallará en el capítulo II, así como las materias en relación a la realidad nacional que reciben.

Cabe señalar que a nivel nacional el conocimiento sobre la Selva es limitado y no está cubierto desde la escuela. Con el objetivo de sesgar el campo de acción se eligió esta universidad por su mirada de amplios escenarios y el planteamiento de propuestas creativas para la solución de problemas de comunicación.

Web site y material acreditado por AIDESEP: su página web presenta información especializada sobre la realidad amazónica. También se revisaron diversas publicaciones avalados por la institución.

Sede de CAAAP: en Lima, Magdalena. Se obtuvo importante información bibliográfica sobre las etnias de la Amazonía peruana.

Sede de Centro Cultural Amazónico José Pio Aza: ubicada en el Centro de Lima, se obtuvo información bibliográfica sobre las etnias de la Amazonía peruana.

\section{c. Método}

El acceso al campo y a los actores se realizará mediante diversas técnicas o herramientas para estudios cualitativos y cuantitativos.

Observación: esta técnica se aplicó en la recolección de datos en los centros poblados de Santo Tomás y Padre Cocha, y en la comunidad de Puerto Prado. El 
objetivo fue ingresar a estos campos para obtener información de primera mano mediante la exploración directa del ambiente físico, social y humano en el que se desenvuelven sus integrantes, así como de sus actividades. Se buscó comprobar la información bibliográfica obtenida respecto a sus costumbres y cosmovisión.

Entrevistas: esta técnica se aplicó en el centro poblado de Santo Tomás, que alberga a una población de ascendencia Kukama Kukamiria. El estilo fue de entrevista abierta, con la finalidad de recoger información de los actores, permitiéndoles expresarse de la mejor manera posible, sin la influencia de la perspectiva del investigador. (Hernández, Fernández Collado y Baptista, 2006, p. 597). El objetivo fue obtener una mirada sobre sus costumbres y cosmovisión.

\section{Repertorios: documentos, registros, materiales y artefactos}

Materiales audiovisuales: fotografías, ilustraciones y videos que sirvieron para conocer el estilo de vida de la comunidad Kukama Kukamiria.

Artefactos: adquisición de vasijas, artesanías y otros artículos utilizados por los miembros de la comunidad.

Registros en archivos públicos: obtenidos en CAAAP, en el Museo Etnográfico José Pio Aza y en línea.

Páginas web de otros investigadores de la población analizada.

Bases de datos y material de difusión de Mincetur y Promperú sobre las comunidades y culturas amazónicas. 


\section{Capítulo I}

\subsection{Marco teórico}

\section{a. Identidad, cultura y acervo cultural}

Identidad y cultura son dos conceptos que se han ido relacionando a lo largo de los años, de tal manera que en la actualidad el uno es indisoluble del otro. Antes de esbozar una definición de identidad, es necesario considerar también la evolución del concepto de "cultura" relacionado a fines del siglo XIX con el "mundo civilizado", donde las poblaciones con un estilo de vida diferente al occidental debían ser "llevadas al progreso y al desarrollo" aún si eso implicaba anular sus tradiciones, costumbres y rasgos esenciales; porque estas simplemente no se reconocían como valiosas.

Posteriormente, el término pasa a describir las características intrínsecas de una población. Cabe señalar que, durante un tiempo, aproximadamente en la década de 1950, el reconocer la multiculturalidad implicaba aún una mirada de arriba hacia abajo con aquellas culturas que no seguían los cánones occidentales establecidos, y que eran vistas con una suerte de espíritu paternalista que consideraba esta diferencia cultural como un bache para el progreso y desarrollo.

Actualmente, al menos en el campo teórico, el término "cultura" es un concepto indivisible con el de desarrollo, no solo desde el punto de vista económico, sino también intelectual, moral y espiritual, lo cual permite a "grupos, comunidades y naciones proyectar su futuro de manera integrada" según la Organización de Estados Americanos (OEA), (Molano, 2007, p. 72-73). Pero esta es una mirada utópica, pues en un contexto como el peruano aún se perciben ciertas costumbres y creencias como propias de gente "ignorante", "serrana", "chola", etc.

Uno de los ejemplos más claros de este recorrido en la concepción del término cultura se observa en la Amazonía peruana. Vista durante mucho tiempo bajo una 
perspectiva desarrollista y colonizadora, era considerada desde la época de la conquista como una zona "inhóspita" y habitada por "tribus salvajes" de naturaleza homogénea, a las cuales era necesario ayudar para que puedan crecer como personas, aún si este crecimiento significaba anularlas como culturas, fusionarlas sin importar sus diferencias, obligarlas a creer en una religión que no comprendían, "enseñarles" a vivir un estilo de vida más individualista y menos en comunidad, etc. Se generó así una visión exotizada, difundida desde la época de la conquista, donde todos los pobladores de la Amazonía eran iguales.

Es a fines del siglo XX cuando comienza a darse otra mirada a la Amazonía, con proyectos sociales que redescubren a las "comunidades nativas, sus particularidades culturales y su situación de dramáticas carencias, lo que tendrá fuertes implicancias para las políticas sociales y educativas de los gobiernos" (Morel, 2014, p. 23). Y aunque esta visualización, este salir de la invisibilidad se materializa en políticas estatales que teóricamente las empoderan, como la Ley de Consulta Previa (Ley No 29785) en Perú, que señala que los pueblos indígenas u originarios deben ser consultados antes de cualquier acción legislativa, administrativa o proyecto que afecte sus derechos, existencia física, calidad de vida o desarrollo, no se han acabado aún las dificultades para los habitantes de la Selva Amazónica.

Esta falta de comprensión a las diferentes culturas amazónicas, aunada a otros factores, económicos y políticos, se refleja en decisiones como la ley que ha declarado zona protegida el espacio de 2'080,000 de la Reserva Nacional Pacaya Samiria, sede durante muchos años de comunidades nativas Kukama Kukamiria. "Hoy los kukamas son tratados como intrusos en las tierras de sus padres y de sus ancestros" (ProyContra, 2019, línea 28). Actualmente, si bien tienen permitido la caza y la pesca en 
determinadas zonas, deben solicitar permisos en lo que consideran su tierra; esta situación ha generado resentimientos.

Pese a que la magnitud de la problemática amazónica es grande, la diferencia con otro, que piensa, se viste y actúa distinto es el problema a resolver en cualquier estudio sobre identidad, la cual se forma precisamente por las características culturales intrínsecas de un pueblo o sociedad. Esto es indispensable para que tenga sentido el concepto "identidad cultural”, tan en boga en la actualidad en los estudios antropológicos contemporáneos y que fusiona dos conceptos estrechamente relacionados: "La identidad cultural es como la firma de un pueblo que lo diferencia de otro. Es el sello de cada sociedad con el cual estampa sus características en las manifestaciones materiales que genera" (Morón, 2012, p.6).

Como se esbozó en párrafos anteriores, esta nueva perspectiva de la cultura y la identidad no implica el fin de los problemas de reconocimiento del otro en el marco de la tolerancia y la inclusión social. Ese "sello" particular de cada sociedad no siempre es aceptado por otras sociedades, que aún se consideran con la potestad de legitimar o no algunas prácticas y creencias.

Esto sucede porque una parte esencial de la identidad, que es el acervo, y que engloba a todas las manifestaciones culturales y artísticas de un grupo poblacional adquiridas por tradición o herencia, como las costumbres y hábitos, no tiene la suficiente solidez en el Perú; se ha perdido por desconocimiento, y a veces se ha negado, por vergüenza. Aunque en esta investigación se opta por considerar que el término acervo es distinto al de patrimonio, siendo el primero algo más material y el segundo más intangible, de corte cultural o moral, es interesante observar cómo Tafur, quien cita a Hernán Mejía, remarca la importancia de ese conjunto de elementos y características propias de una población en la formación de la identidad: 
Cuando hablamos de patrimonio cultural de un pueblo hacemos referencia a ese conjunto de elementos de naturaleza material e inmaterial que una sociedad de común acuerdo adopta como propios y que son la base de la identidad cultural. [el subrayado es nuestro]. Una primera conclusión evidente es que todos los pueblos sobre la tierra poseen una identidad cultural primaria, una manera de ser y hacer en la vida que está determinado por su propia visión del mundo, por una serie de valoraciones por medio de las cuales otorgamos sentido y significados a ciertos bienes y expresiones simbólicas. (Tafur, 2018, p. 18).

En el Perú aún persiste el desconocimiento de otras culturas, especialmente las de la Amazonía, lo cual implica una identidad nacional fragmentada, donde hay una parte que se desconoce. La idea no es obtener una identidad uniforme; sino que se amplíe la mirada hacia culturas que son parte de la herencia y que no se valoran porque no se conocen. Podría decirse que, en general, el peruano no ha tomado posesión de su acervo cultural.

Aunque durante algunos momentos históricos la identidad se definió como “dualidades absolutas, en donde la identidad de un grupo se definía solamente en contraste y en oposición a otros", la globalización ha hecho necesario comprender la identidad como un fenómeno en movimiento.

Una de las razones de este desconocimiento es el difícil acceso a la Amazonía peruana. Por ejemplo, para viajar a Iquitos se requieren solo 2 horas 11 minutos en avión; pero el viaje por tierra es de 25 horas en bus, hasta Yurimaguas, 12 horas en barco recorriendo los ríos Huallaga y Ucayali hasta Nauta y, finalmente, 1 hora y 45 minutos en taxi hasta Iquitos (más tiempo si este último tramo se realiza en bus). En cambio, ir al Cusco, Arequipa o Piura por tierra toma mucho menos tiempo y es más 
económico. Así, se puede entender, en parte, por qué la Selva sigue siendo aún poco conocida para gran parte de la población peruana.

Algunos datos que confirman este punto: en el listado de Promperú de los 15 departamentos más visitados en el año 2018, solo figura San Martín entre los departamentos de la Selva baja. Asimismo, en 2016 solo el 2\% jóvenes entre 18 a 24 años visitó esta ciudad, mientras que el 1\% viajó a Loreto. Lo que deja claro que viajar a la Selva no es habitual en este grupo objetivo. Asimismo, para la presente investigación, se encuestó a 60 estudiantes universitarios de comunicación de la Universidad de Lima: el 25\% nunca visitó la Amazonía peruana y de la lista de lugares planteados como alternativas, Iquitos fue el más nombrado (47\%); sin embargo, cabe señalar que la ciudad más conocida de San Martín (Tarapoto) no estuvo en la lista, sino su capital Moyobamba, lo que puede haber generado un sesgo en las respuestas.

\section{b. Perú, diverso y pluricultural}

En el marco de la diversidad peruana, distintas categorías han pretendido completar la idea de identidad en el Perú: multiculturalidad, pluriculturalidad, interculturalidad. En la presente investigación se descarta el término "multiculturalidad", que para algunos autores remite a comunidades homogéneas y cerradas en sí mismas, que no interactúan con otras, y que cuando se utilizó en educación, hasta antes de 1970, negaba el aporte cultural de culturas consideradas como "inferiores". No es el caso del Perú donde la interacción (en teoría acción, relación o influencia recíproca) entre culturas es una constante, por el continuo flujo migratorio generalmente hacia la capital; históricamente, el choque cultural que más marcó la faz de Lima fue producto de las oleadas migratorias de los Andes a la ciudad, que tuvo su 
mayor apogeo en la década de los 80 y se observa en manifestaciones culturales como la música y la gráfica popular.

Pero Lima no es todo el Perú; en ese sentido, en todo el país, dos términos que describen sus características culturales son "pluriculturalidad" e "interculturalidad"; el primero, considera la coexistencia social de diferentes culturas, mientras que el segundo alude a un intercambio de saberes entre las culturas, respetando la diversidad. (Bernabé, 2012, p. 69). Este último concepto rebasa el término de la simple tolerancia, pues implica el enriquecimiento mutuo entre dos culturas distintas; ampliamente conocidas son las fusiones de culturas en Perú, con aportes chinos, africanos, italiano, entre otros. Pues precisamente es la diversidad lo que nos identifica como peruanos. Para Hernández, esta palabra, junto con el "cambio" define nuestra "identidad":

La identidad, a mi entender, es el resultado de un proceso de unión y de síntesis de los diferentes valores de una colectividad, sean ellos geográficos, étnicos, lingüísticos, que constituyen las capas superpuestas o sucesivas de un todo. Cada pueblo en este vasto mundo posee una identidad más o menos definida y homogénea, de la que, lamentablemente, algunos no son conscientes. Conviene precisar que la identidad de un pueblo es necesaria e inevitablemente cambiante, incluyente, pues de otra manera llevaría sea al aislamiento sea a formas inaceptables de exclusión. (Hernández, 2000, p. 7).

Pero ¿es posible hablar de pluriculturalidad y de interculturalidad si hay desconocimiento de varias culturas? Las encuestas que se incluyen al final del presente marco contextual revelan un gran desconocimiento de etnias y costumbres de la Amazonía, siendo las más nombradas aquellas más difundidas y exotizadas. 
Sobre este desconocimiento Sonaly Tuesta Altamirano, conductora del programa Costumbres y designada en 2015 por el Ministerio de Cultura como "Personalidad meritoria de la cultura", señala:

Es un tema bastante "clandestino", pues lo que conocemos y lo que se habla de selva es totalmente irreal frente a lo que realmente sucede en las regiones selváticas. Nuestro país es un país amazónico, tiene más selva que sierra, pero es conocido mucho más como un país andino. Hay un desconocimiento de la selva en si como paisaje, como bosque, como pulmón del mundo y del Perú, pero también hay mucho desconocimiento sobre la diversidad y sobre la gente que vive en esta zona. En el Perú hay muchísimas etnias y solamente nos restringimos a una o dos (...); con lo poco que conocemos homogenizamos todo. (Tuesta, 2019, entrevista).

Es este desconocer, no saber, una de las murallas que dificultan el camino del peruano hacia una identidad coherente, con un acervo sólido que contemple los diferentes aspectos que la nutren, empoderan, enriquecen y permiten la comprensión del otro, con una mentalidad basada en la tolerancia y el respeto.

Y es que: "En países como el Perú, caracterizados por la diversidad, el mestizaje y la asimilación de grupos migrantes, se pueden apreciar dificultades en la construcción de un estado nacional unificado e inclusivo". (Rottenbacher y Espinosa, 2010, p. 153). Pero la solución no es anular la diversidad, vista muchas veces como una problemática para las políticas estatales; para Tuesta, esta diversidad es el mayor valor que tenemos en nuestro país, no solo en flora y fauna, sino también a nivel cultural; lograr que cada una sea valorada y, sobre todo, que se valore a sí misma, es una labor ardua. Para ello, 
el conocimiento es importante, porque este genera respeto e interés. "Tiene que hacerse un trabajo que realmente integre, y no hablar de una inclusión solamente de discurso", (Tuesta, 2019, entrevista), y es esta reflexión la que engloba la importancia de esta investigación.

Asimismo, Carlos Rivadeneyra, responsable de Grados y Títulos de la Universidad de Lima señala que: "El gran muro del país son los Andes. Hasta ahí llegamos. Detrás de este está el gran jardín amazónico. De cuando en vez lo visitamos. Y nos hemos olvidado de ese país. Allí hay muchas nacionalidades, etnias, lenguas, costumbres, muchísima riqueza. Nos hemos acordado de la riqueza material: petróleo, talar los árboles, el oro. Pero conocemos poco su riqueza cultural y menos lo aprovechamos". (Rivadeneyra, 2030, entrevista).

\section{c. Etnia y diversidad}

Las etnias son comunidades agrupadas por características raciales, lingüísticas y culturales similares, las cuales desarrollan una "identidad étnica" o propia, que conlleva a la capacidad de diferenciar el "nosotros" en relación a "los otros".

A principios del siglo XX existían en la Amazonía Peruana 78 grupos étnicos, según Wise y Rivero, citados por Barrantes y Glave (2014), aunque dichos grupos se han ido integrando o extinguiendo durante el contacto con la población occidental (p. 57). Según los registros del Centro Amazónico de Antropología y Aplicación Práctica (CAAAP) actualmente existen 68 grupos étnicos entre andinos y amazónicos, de los cuales más del 80\% habitan en la Amazonía peruana. Cada uno de ellos está compuesto por un determinado número de comunidades (más de 1400 en la Selva).

Asimismo, los datos, tanto del CAAAP como del Ministerio de Cultura, registran un total de 16 familias etnolingüísticas en todo el país que agrupan a 56 lenguas 
indígenas. Tres de estas familias: Aru, Quechua, y Uro-Chipaya se relacionan con etnias andinas, y una de ellas, Romance, al grupo étnico denominado Castellano. Así, en la Selva se hablan distintas lenguas de 12 familias etnolingüísticas.

Los números expuestos dejan constancia de que la heterogeneidad es un término que define a la Amazonía en lo que respecta a la diversidad étnica y cultural (además de su vasta variedad de recursos naturales).

Pero de estos grupos étnicos, las que más se identifican en Lima son apenas un 3\%: los Shipibo-Conibo y los Asháninkas. La selva termina siendo homogeneizada a pesar de que cada una de estas etnias se manifiesta culturalmente de manera específica, sea a través de la danza, el canto, el tejido o la pintura, expresiones que si no se observan al detalle parecen partir del mismo estilo de vida y concepción del mundo o cosmovisión.

En este entorno diverso es importante respetar las diferencias entre etnias, aún si son sutiles, pues tienen una razón de ser en la vida de cada grupo. Tuesta cita a los Yanesha, los Machiguenga (o Matsiguenga) y a los Yine Yami, con manifestaciones culturales similares pero cada uno "con la forma de expresión que necesita para poder existir y para tener ese contacto con la naturaleza", lo cual es de suma importancia en una zona donde la subsistencia depende de la vida en armonía con el medio ambiente. (Tuesta, entrevista).

También es importante la preservación de las lenguas, algunas de ellas en proceso de recuperación (como es el caso de la comunidad Kukama Kukamiria, que en la década de 1980 inició una campaña para la revalorización de su idioma). El lenguaje permite no solo la identificación y valorización interna como grupo sino también la preservación de cosmovisiones y leyendas que fortalecen a estas etnias como población y comunidad. 


\section{d. Problemática de las etnias amazónicas}

La aculturación, fusión y homogeneización de las etnias amazónicas comenzó durante la época de la conquista. Manuel Marzal (1981) considera tres instancias en este proceso: periodo de conquista (1532-1600); periodo misional (1630-1830) y periodo nacional (1830-1981, año en que fue escrito el informe). (p. 237). Con algunas diferencias, Jesús San Román distingue siete instancias en la historia de estas poblaciones: periodo indígena (hasta 1542), periodo de la penetración misionera (15421769), periodo de nacimiento del capitalismo (1769-1880), periodo del caucho (18801914), periodo de recesión o depresión económica (1914-1943), periodo de integración de la selva a la vida nacional (1943-1970) y periodo del petróleo y de la coca (19701990). (San Román, 1994).

Entender la situación previa a la llegada de los españoles es importante para comprender la realidad amazónica. Esto fue estudiado por San Román en el periodo indígena, y explica las características fundamentales de la vida de los grupos nativos de la Amazonía antes del proceso de aculturación, lo que permite observar las grandes diferencias entre ellos y la cultura que posteriormente les fue impuesta a nivel religioso, económico y social.

\section{- $\quad$ El nativo antes de la Conquista}

En un inicio las expediciones no encontraron una sociedad homogénea sino más bien diversos grupos independientes que resultaba difícil diferenciar, y estaban muchas veces en guerra u oposición. San Román recoge distintos testimonios de misioneros y sacerdotes de la época sobre las características psicológicas de los indígenas, observándose, desde esta fase, la heterogeneidad en las tribus, cada cual con una historia distinta y, por ende, una psicología diferente. 
'Las formas estereotipadas de 'indio' con su color exótico, son slogans de propaganda, ciertamente muy llamativos, pero alejadas de la realidad". (San Román, 1994, p. 28).

Asimismo, es importante observar que estas tribus eran muchas pero pequeñas, constituidas por 40 y hasta 500 personas. Pero no obstante la diversidad, las estructuras sociales y económicas eran semejantes. Eran seminómadas, cazadores y pescadores; además, en una zona tan rica en frutos naturales, también eran recolectores; no conocían la agricultura ni la ganadería, las cuales se introdujeron en la región con la llegada de los misioneros.

Además de su importancia al cubrir la necesidad de la alimentación, la caza era (y es) una ocupación muy apreciada en la cosmovisión del hombre amazónico, con un valor simbólico de fuerza vital; por eso, a veces, se acompaña de prácticas rituales: "El hombre de la selva, al matar un animal, se apropia de su fuerza, una fuerza poderosa que le da valentía y seguridad. .... El hombre se perfecciona y dignifica en la caza, cosa que no sucede con los trabajos de chacra que considera de nivel inferior”. (San Román, 1994, p. 40).

Esta estructura socio-política, hizo posible una estructura económica colectivista-comunitaria, donde era común compartir lo obtenido en la caza o pesca con todos los miembros de la comunidad.

Otra característica importante, por la necesidad de supervivencia, era la de ser grupos guerreros y en constante pugna, con una actividad política casi inexistente. La cabeza era el Curaca, que obtenía su autoridad gracias a su prestigio, y las decisiones se tomaban con la participación comunitaria de los ancianos o de los miembros masculinos de las tribus. Sin embargo, la jerarquía del Curaca era entendida de manera distinta a la que ostenta un líder occidental; 
para los miembros de las tribus era solo el dirigente de las guerrillas, pero en los demás aspectos no lo reconocían como su superior.

Finalmente, dos matices aparentemente incompatibles en el pensamiento occidental caracterizaban a los miembros de las tribus: una fuerte individualidad, pero, al mismo tiempo, un profundo espíritu comunitario. "El hombre de la tribu podía vivir solo, sin necesidad de ayuda, con dominio de todas sus reacciones; pero, al mismo tiempo, vivía una vida de comunidad intensa, cooperando y cediendo a los intereses del grupo. Su educación era orientada hacia esta doble vertiente”. (San Román, 1994, p. 35).

Todas estas características se trataron de anular durante el proceso de occidentalización que significó la Conquista.

\section{- El choque cultural y la aculturación}

Ante esta panorámica, es posible entender por qué el estilo de vida y religión propuesto durante la penetración misionera fue tan difícil de aceptar para muchos nativos.

Como se indicó con anterioridad, Marzal data el inicio del período misional en 1630 mientras que San Román en 1542; cabe señalar que este último ha considerado también en esta etapa las primeras expediciones de los conquistadores Francisco de Orellana, Pedro de Ursúa y del capitán Palacios, cuyos intereses eran más que todo económicos.

Sin embargo, "la población nativa no va a ser sometida de un modo sistemático hasta el segundo tercio del siglo XVII”. (Marzal, 1981, p. 233); eso es posible cuando las noticias de los expedicionarios interesaron a las Órdenes Religiosas, especialmente jesuitas y franciscanos, que emprendieron la tarea de 
evangelizar a los nativos de la Selva. De acuerdo a las órdenes del Virrey Toledo instalan un sistema de pueblos-reducciones donde, si bien mantenían algunas costumbres indígenas, estaban integrados por grupos de etnias distintas, lo que fue uno de los motivos de las diversas rebeliones que se dieron lugar en esta etapa.

Por otro lado, de ser grupos seminómadas, cazadores, pescadores y recolectores, los nativos fueron obligados a tener un estilo de vida sedentario, donde la agricultura era la actividad más importante. Asimismo, la estructura económica con rasgos individualistas contrastaba con la organización anterior, colectivista y comunitaria.

Cuando los misioneros jesuitas fueron expulsados de la Selva en 1769, el gobierno español tomó las riendas y siguió con la misma dinámica de considerar a las tribus como homogéneas a pesar de su diversidad. Pero de ser considerados “paganos” pasaron a ser vistos como "salvajes" que servían de mano de obra útil para la explotación económica. Este aspecto se acrecentó durante la fiebre del caucho de 1880 a 1914, que implica el ingreso de la Selva al capitalismo; un gran grupo de extranjeros llega a la zona y los nativos se ven obligados a emigrar o a trabajar, bajo condiciones de estrechez, para el sistema en vigencia. El derrumbe del caucho en 1914 origina una crisis económica y social, y la Selva se ve afectada por el abandono y desolación que causó el retiro de aquellos que habían llegado a usufructuar sus tierras y que emprendían la retirada dejando devastación y muchos lugares despoblados.

La caída del caucho benefició a algunos indígenas, que pudieron volver a sus tierras. No obstante, la Selva siguió siendo explotada en la búsqueda de 
encontrar otra "mina de oro" como lo fue el caucho: madera, barbasco, arroz, azúcar, etc.

A partir de 1943 la Selva pasa a integrarse en forma paulatina a la vida nacional, con la implementación de la carretera Lima-Pucallpa y otras vías que permitieron el acceso de Pucallpa a otras zonas del país. Sin embargo, esta idea de una sola Amazonía, homogénea, continuaba. La zona era vista, hasta hace poco más como territorio inhóspito propicio para la expansión territorial (por las políticas desarrollistas, expansionistas y de extracción de los recursos de diversos gobiernos precedentes), que como hábitat de muchas culturas milenarias. No es pues una sino "muchas Amazonías", como señala Morel en la recopilación de textos Amazonía peruana y desarrollo económico (Barrantes y Glave editores, 2014, p. 23).

En este recorrido histórico la Selva ha sufrido los estragos de la colonización, tanto económicos como a nivel social, las pérdidas en tierras y hombres durante las crisis del terrorismo y del narcotráfico y las políticas desarrollistas y extractivistas que no tomaron en cuenta la verdadera naturaleza de la Amazonía y sus pobladores.

\section{e. Etnia Kukama Kukamiria}

Este grupo es la fusión de dos grandes pueblos, los Cocama o los Gran Cocama (Kukama) y los miembros de la Pequeña Cocama (Kukamiria), llamados también los "guallagas" que habitaban a orillas del río Huallaga. Cabe señalar que la escritura del nombre de esta etnia fue durante mucho tiempo Cocama Cocamilla, pero luego, en concordancia con su lengua, se denominaron Kukama-Kukamiria. Por un tema de orden metodológico, en el desarrollo de este ítem se utilizará su denominación actual. 
Su nombre, constituido por dos vocablos de la familia lingüística tupí guaraní a la que pertenece su lengua significa "chacra pequeña amamantada". Así, en la palabra Kukama ku significa "chacra" y kama "seno, teta, mamas" ("se amamanta de la chacra”); y en Kukamiria, miri se traduce como 'delgado, pequeño, chico' e ia, como ‘corazón, centro', respectivamente. (Rivas, 2004, p. 16).

Sus pobladores se caracterizan por el dominio que han logrado de tierras fácilmente inundables (várzea), siendo considerados los grandes pesqueros de la Selva por su amplio conocimiento y destreza de técnicas ancestrales en pesca y desarrollo de instrumentos para tal fin. Por su dominio de las aguas y habilidades guerreras, durante la etapa de la colonización fueron conocidos como "Los piratas del río".

Según la Base de Datos Oficial de pueblos Indígenas u Originarios (BDPI) del Ministerio de Cultura, su población se estima en 21,658 personas. Actualmente sus habitantes se encuentran en Pucallpa (San Pablo de Tushmo), alrededores de Iquitos (poblados de Santo Tomás, Rumococha y Santa Clara), el río Putumayo, cerca de la frontera con Colombia y en Nauta (Loreto).

La ciudad de Nauta es especial en la historia de esta etnia, ya que fue fundada por el líder de los nativos kukama Manuel Pacaya en 1930, luego de que abandonasen el pueblo de La Laguna y se asentasen a orillas del río Marañón, cerca de la confluencia con el río Ucayali; originalmente la denominaron "Mauta" (o tinaja en su lengua), pero cuando obtienen la autorización para establecerse en ese lugar como pueblo el nombre se modifica a Nauta, cuyo significado es "marinero o navegante".

Los Kukama Kukamiria padecieron mucho las consecuencias de la aculturación, resultado de Conquista. Actualmente, pueden ser fácilmente confundidos pues todavía algunos de ellos niegan su herencia cultural, al punto de preferir ser considerados "mestizos" o "campesinos". Por este motivo, el antropólogo Anthony Wayne Stocks 
(1981) los presentó en 1981 como "los nativos invisibles" (citado por Marzal, 1981, p. 243).

Su hábitat natural, a orillas de los ríos y su tendencia migratoria en búsqueda de mejores tierras los obligó a socializar más con las sociedades dominantes; en ese contexto, se vio precisado a eliminar características culturales visibles que fueran motivo de discriminación o disgusto. Así, el pueblo Kukama Kukamiria ha eliminado en gran parte manifestaciones culturales como la vestimenta tradicional, las pinturas faciales o el idioma; sin embargo, como señala Rivas (y se comprobó en el trabajo de campo), aún quedan “....sus valores, creencias; es decir, su aspecto simbólico. La experiencia con este pueblo me permite ampliar esta visión, pues un pueblo no es tan autodestructivo como para eliminar de su práctica las herramientas y el saber hacer en su medio ambiente que le permiten su subsistencia diaria”. (Rivas, 2004, p. 19).

Durante el trabajo de campo, Pablo Taricuarima Paima hijo, kukama de nacimiento, artista plástico y gestor cultural, señaló que aún subsiste esta situación entre algunos de los pobladores; asimismo, los integrantes de su familia, Pablo Taricuarima Pinedo, padre, y doña Rita, madre, manifestaron que el idioma se fue perdiendo porque hasta hace unos pocos años era vergonzoso hablarlo. Efectivamente, a mediados de 1980 la lengua nativa Kukama Kukamiria estuvo en peligro de extinción, lo que se está actualmente tratando de revertir luego de la asociación de esta etnia con AIDESEP; en 2014 fue reconocida como idioma indígena oficial, con un alfabeto que consta de 5 vocales y 12 consonantes.

Por otro lado, enfrentan serios problemas por la titulación de sus tierras y el uso de los recursos naturales dentro del territorio protegido de la Reserva Nacional Pacaya Samiria; situación que no solo ha afectado a los Kukama Kukamiria, sino también a otras siete culturas: los Shipibos Conibo, los Shiwilu (Jéberos), los Kacha Edzé o 
Uraninas (Shimaco), los ribereños y los mestizos recientes. Un total de aproximadamente 92.125 personas distribuidas en 208 centros poblados (caseríos, poblados menores y comunidades), según los datos del Plan Maestro Reserva Nacional Pacaya Samiria 2009-2013 (Ministerio del Ambiente y otros. 2009, p. 30).

\section{- $\quad$ Historia de los Kukama Kukamiria}

Los orígenes de los Kukama Kukamiria se remonta a tres siglos antes de que los primeros Cocama fueran vistos por primera vez por los españoles (aproximadamente en 1250 d.C.) Pertenecen al grupo lingüístico tupí-guaraní, compuesto por diversos grupos étnicos que en ese entonces ocupaban gran parte de la costa de Brasil y diversas áreas de la selva amazónica; estos pueblos, aunque emparentados, se enfrentaban constantemente unos con otros, y se caracterizaban por el etnodinamismo o constantes movimientos migratorios, que según Agüero, citando a Branislava, se fundamentaban tanto en el "ethos guerrero" (manifestado en la agresión contra otras etnias sea para expandirse, apoderarse de sus tierras, demostrar su poderío o tomar venganza o desquite por ataques previos), como en la mitología, al estar motivadas estas migraciones por la necesidad de buscar la "Tierra sin mal" (el "Yvy mara ey"), espacio ideal pleno de abundancia. (Agüero, 1994, p. 32-33).

Los Tupí-Cocama se ubicaron al comienzo en las zonas inundables del cauce de la cuenca baja del río Ucayali y desde allí se expandieron a otras tierras selváticas semejantes. Como se señaló, los Cocama asentados a orillas del Ucayali pertenecían a una etnia y los Cocamilla, en el bajo Huallaga, a otra.

Durante las primeras expediciones de la conquista se menciona por primera vez a los Gran Cocama en las crónicas de Juan Salinas de Loyola de 1557, 
aunque el proceso de evangelización de la población comenzó casi 100 años después, cuando las fuerzas españolas irrumpieron en la zona con la finalidad de expandir la religión, además de utilizar la fuerza laboral de sus pobladores. El proceso significó la muerte de muchos nativos debido a la serie de epidemias que no pudieron enfrentar, lo que originó diversas rebeliones. En 1643, durante una disputa por la opresión española, los Cocamilla junto a los Jéberos huyeron a la zona de la Gran Cocama.

En siglos posteriores, durante la fiebre del caucho, se reclutó a Cocamas Cocamillas para la fuerza laboral. Muchos migraron a Brasil para trabajar en haciendas o se ubicaron en otras zonas de la Amazonía.

\section{- Sobre el mito y la cosmovisión Kukama}

Dominadores de un terreno fácilmente inundable y habitantes milenarios de las orillas de los ríos, los Kukama Kukamiria son pescadores por excelencia, labor que realizan de manera individual o en grupo; la caza, aunque es un importante medio para la obtención de alimento, y la recolección son actividades secundarias. Caza y pesca están, sin embargo, estrechamente relacionados en la cosmovisión Kumama. El “Ipukiari”, por ejemplo, define al 'gran pescador', pero a la vez al 'gran cazador, aquel que sabe matar'. (BDP, s/f, p. 3).

Los relatos que en cada pueblo explican sus orígenes y creencias y configuran su cosmovisión es lo que se denominan mitos. Aparentemente llenos de incongruencias como animales imaginarios y dioses referentes del bien y del mal, su importancia reside en que sus simbolismos explican la realidad que rodea a un grupo o pueblo. El pensamiento mítico fue muy importante en todas las culturas; hasta que se dio paso a la razón humana y al pensamiento científico, que 
se opuso a explicar las cosas con un fundamento que no pudiera sustentarse desde la razón; el mito, sin embargo, no se perdió, y es hoy en día parte de la cultura universal, y es interesante observar cómo algunos personajes son similares, en lo esencial. En diversas culturas hay semejanza entre los mitos sobre la creación del universo; asimismo, la "Tierra sin mal" de los Kukama Kukamiria es muy similar a la idea de la Tierra Prometida para los judíos (buscada en vida en la historia) y a los Campos Elíseos, que albergaría las almas de los romanos después de su muerte.

El mito nace por la necesidad de alcanzar una comprensión general o "total” del universo. Para Levi Strauss “... se trata de un modo de pensar que parte del principio de que si no se comprende todo no se puede explicar nada, lo cual es absolutamente contradictorio con la manera de proceder del pensamiento científico, que consiste en avanzar etapa por etapa...”. (Levi Strauss, 1987, p. 38). Y aunque según el autor a través del mito no es posible dominar materialmente el medio, lo cual sí se logra con la ciencia, el mito empodera al hombre y a sus sociedades porque les da la ilusión de entender el universo y de comprenderse como cultura.

Para las culturas de la Amazonía el mito no es algo ajeno. "Simbolismo, Magia, Arte y Naturaleza han ido de la mano en las culturas de los indígenas de la Amazonía y siempre bajo una relación de armonía con el hábitat y los seres que lo integran, de tal forma que sus manifestaciones naturales y estéticas y su interpretación mágico-simbólica han permanecido en el tiempo y en uso hasta hoy en día”. (Ochoa, 2002, p. 204). 
Gran parte de la mitología Kukama gira en torno al "Yvy mara ey" (Tierra sin mal) o la "tierra donde no se muere". Según Ochoa, es muy probable que el origen de este mito se encuentre en la herencia cultural de sus antepasados Tupí.

Por otro lado, al ser la pesca fuente de supervivencia para los Kukama Kukamiria, el agua y sus seres han dado origen a una serie de personajes e historias simbólicas con los cuales explican su relación con el mundo. Por ejemplo, el Ini Yara ("Nuestro dueño") es el personaje principal en los mitos de origen kukama, y está representado como "un gran pescador que va recorriendo ríos y lagunas en una canoa o balsa" (Rivas, 2004, citada por el BDPI, p. 4).

Otros personajes de la cosmovisión Kukama relacionados con el mundo acuático son la Ipira mama o "dueña del agua", que "decide la merma o la creciente de las aguas de ríos y cochas"; Muiwatsu o madre de las cochas; o la gran mujer boa, madre de Kémarin, el primer hombre kukama cuyo padre fue Kémari, descrito hoy como una especie de ángel o Dios, quien pudo preñar a la mujer boa por haber cumplido con las "dietas y conductas" (El ojo verde, 2000, p. 157-158). Cabe señalar que los chamanes en la Amazonía hacen dietas muy estrictas, sin consumo de carne, sal, azúcar, ni contacto sexual, con el objetivo de depurar su energía para el aprendizaje o la sanación, a través del consumo del Ayahuasca u otras plantas.

Finalmente, según su cosmovisión, "el hombre establece una relación de alianza con los utensilios de pesca y considera que, al igual que él, estos tienen independencia para escoger entre pescar o no." (Rivas, 2004, citada por el BDPI, p. 4). 


\section{f. La Generación Z}

Nacidos entre 1996 y 2010 (aunque algunos autores señalan el período para los nacidos entre 1992 y el 2005), sus edades están actualmente entre los 9 y los 24 años. Sus integrantes forman parte de la primera generación totalmente digital, por eso también son conocidos como la Generación Web o Generación Net y son llamados “nativos digitales", nombre con el que los bautizó Marc Prensky en 2001. Al haber nacido en un entorno tecnológico muy avanzado, tienen acceso a Internet, telefonía móvil, dispositivos tecnológicos y redes sociales desde temprana edad.

\section{- $\quad$ Lo que los caracteriza}

Independencia, individualidad, impaciencia, manejo de grandes cantidades de información, capacidad de hacer muchas cosas a la vez (multitask), desinterés por la política, interés en causas de responsabilidad social, cívica y colectiva, y dificultad para aceptar reglas y horarios establecidos son algunas de las características de esta generación. Por eso, suelen cuestionar los trabajos tradicionales y priorizar la innovación y la independencia laboral. Además, al haber crecido en un mundo que cambia rápidamente, han desarrollado la habilidad de adaptarse fácilmente al cambio.

Sobre la interconectividad y su relación con la tecnología, tienen gran facilidad para manejar equipos digitales de última generación y desenvolverse plenamente en las redes sociales. En la actualidad la interconexión es inmediata con pares que cuenten con la misma tecnología. "Crea tu propio cuarto conectado, allí donde poder imaginar y construir el mundo que quieres”. (Zafra, 2010, p. 170). La interconectividad está también en el campo laboral y ya no es necesario salir del espacio doméstico para trabajar. 
Asimismo, es cada vez más común que propongan o difundan soluciones a problemáticas sociales y ecológicas en sus comunidades virtuales; conciencia que han desarrollado gracias a que siempre han tenido acceso a una gran cantidad de información. Situaciones de responsabilidad social como el calentamiento global, el cambio climático la violencia, el consumo de alimentos veganos, los incendios en la Amazonía, entre otros, son parte de su interés.

Esta facilidad de obtener mucha información tiene, sin embargo, su contraparte, y es el de haber mermado la capacidad de atención (presentándose ahora en forma discontinua) y el pensamiento lógico racional (reemplazado por uno superficial, que salta de un tema a otro).

Pero, por otro lado, su modo de aprender es el juego y el entretenimiento, y el hecho de estar expuestos a constante y variada información, que llega a ellos en forma no lineal ni secuencial, sino discontinua y poco lógica, los hace capaces de juntar ideas aparentemente poco coherentes, abriéndose un amplio camino para la creatividad.

Al ser el Internet un instrumento de búsqueda inmediata, esta es una generación poco tolerante, que busca la satisfacción inmediata a sus disyuntivas. Por eso prefieren "googlear" a leer un libro impreso, y la imagen al texto (Instagram está desplazando a Facebook por este motivo).

Sobre el individualismo que los caracteriza, cabe señalar que las relaciones sociales cada vez son menos personales; muchas reuniones son ahora en línea (este texto se escribió antes de la Pandemia 2020; ahora, esta realidad es evidente en todas las edades y niveles). Así, las relaciones interpersonales se ven afectadas, lo cual no resta merito al hecho de que, a nivel virtual, muchos de estos 
jóvenes son capaces de mover grandes masas de gente, como lo hacen los conocidos Influencers.

Tecnologías importantes para las generaciones precedentes como el correo electrónico, la televisión tradicional y el cable resultan obsoletas para esta Generación. Esperar a que acabe una película para ver la que sigue no va de acuerdo con lo que están dispuestos a esperar para lograr un objetivo. Por eso, hoy en día la TV es utilizada para ver películas de descarga continúa utilizando plataformas como Netflix, que permite escoger la serie o película en el momento deseado y verlas por streaming sin ni siquiera esperar un tiempo por la descarga. Los tablets, laptops y smart phones son equipos típicos de los miembros más pudientes de la Generación Z.

Este cambio de tecnología de transmisión a interactividad es el pilar de la generación Z, quienes desean ser usuarios y no limitarse a ser simples espectadores u oyentes.

Precisamente por todas estas características, los miembros de esta generación aprenden de manera lúdica, por lo que se debe apelar al entretenimiento, la comunicación y a la creación de comunidades en toda propuesta de aprendizaje.

\section{- Jóvenes y conocimiento de la selva amazónica}

La Amazonía peruana es una zona poco visitada y conocida, tanto a nivel de territorio como de la variedad de culturas y cosmovisiones que presenta. Así lo revela la encuesta realizada en la Universidad de Lima a 60 estudiantes de la Facultad de Comunicación, cuyas preguntas y gráficos de resultados pueden observarse en el anexo 2. 
En líneas generales se destaca en esta encuesta que Iquitos es el lugar más concurrido de la Selva Baja o bosque tropical (lo cual difiere con los datos de Promperú, que señalan a San Martín como el lugar más visitado). Como ya se indicó en el desarrollo de la investigación, no hay forma rápida de llegar a Iquitos de manera directa que no sea en avión. Por eso quizá zonas como Tarapoto y otros sitios de la Selva Alta o Ceja de Selva como Tingo María, La Merced, Villa Rica y Oxapampa, entre otros, fueron nombrados por los encuestados, ya que son zonas a donde es más sencillo llegar en transporte público.

Por otro lado, es preocupante señalar que el $25 \%$ de los encuestados no conoce ninguna de las opciones citadas (Iquitos, Pucallpa, Moyobamba, Chachapoyas y Puerto Maldonado) ni señala algún otro sitio de la Selva que haya visitado. (Ver Gráfico 1 del Anexo 2).

Asimismo, se detecta un conocimiento muy limitado de los personajes o mitos de la Amazonía Peruana. El Chullachaqui y el Bufeo Colorado son los más conocidos, además del Tunche. La "Tierra sin mal” de la mitología Kukama solo fue señalada por dos de los encuestados. Pero más alarmante aún: el 20\% de los encuestados señaló no conocer a ningún personaje de la Amazonía peruana, como se registra en el Gráfico 2 del Anexo 2.

En cuanto a las etnias cabe señalar que a nivel teórico los estudiantes sí tienen presente el significado de este concepto; el 99\% indicó saberlo y marcó como verdadera la alternativa más acertada en las opciones: "Comunidad humana que comparte un conjunto de rasgos de tipo sociocultural (cultura, religión, lengua) y origen geográfico". Sin embargo, el punto a tener en cuenta es que las etnias de la Sierra son mucho más conocidas que las selváticas. 
$\mathrm{Al}$ respecto, en lo que respecta a la Sierra y con la posibilidad de marcar más de una opción, se registraron 36 respuestas para los Aymaras, 34 para Lo Quechuas y 26 para los Uros, entre otras etnias conocidas; es decir casi el 50\% de la muestra de encuestados conoce uno o varias de las indicadas. Mientras que en la Selva fueron los Shipibo Conibo los más conocidos, con 47 respuestas (78\%), mientras que las otras opciones tuvieron un rango de respuestas de 2 o 7 personas; para los Kukama Kukamiria, actores de la presente investigación, solo se registraron 7 respuestas $(11.5 \%)$.

Además, como parte de las respuestas sobre etnias de la Sierra tres estudiantes indicaron conocer a los "Shipibos" y uno de ellos a los "Kukama", como se sabe, dos etnias selváticas; lo que revela desconocimiento, distracción o poco dominio de la información. Sobre las etnias de la Sierra, 11.6\% estudiantes no conocen ninguna, mientras que el $15 \%$ no conoce ninguna etnia selvática. (Ver Gráficos 4, 5 y 6 del Anexo 2).

Finalmente, en la pregunta 9, orientada a entrever la visión actual del desarrollo y la cultura, la respuesta del 93.3\% revela una visión que, al menos en teoría, respeta las sociedades distintas, mientras que el $6.7 \%$ considera que el mundo "civilizado", entiéndase, cultura occidental, es el lugar idóneo para el desarrollo de las etnias amazónicas.

\section{g. Apuntes de la novela gráfica}

\section{- $\quad$ Antecedentes de la narración con imágenes}

A lo largo de la historia el hombre se ha comunicado con imágenes desde que comenzó a explorar las posibilidades expresivas de estas; ejemplos distantes de imágenes sin texto que comunican una idea o concepto son las obras del arte 
rupestre, los jeroglíficos egipcios, los códices mayas, griegos, islámicos, etc. En los párrafos siguientes se observará que: "La narración visual de historias es un tema central en la historia universal del arte, evidente en muchos cuadros que ilustran la mitología clásica griega, las leyendas, los hechos religiosos o históricos”. (Wigan, 2008, p. 8).
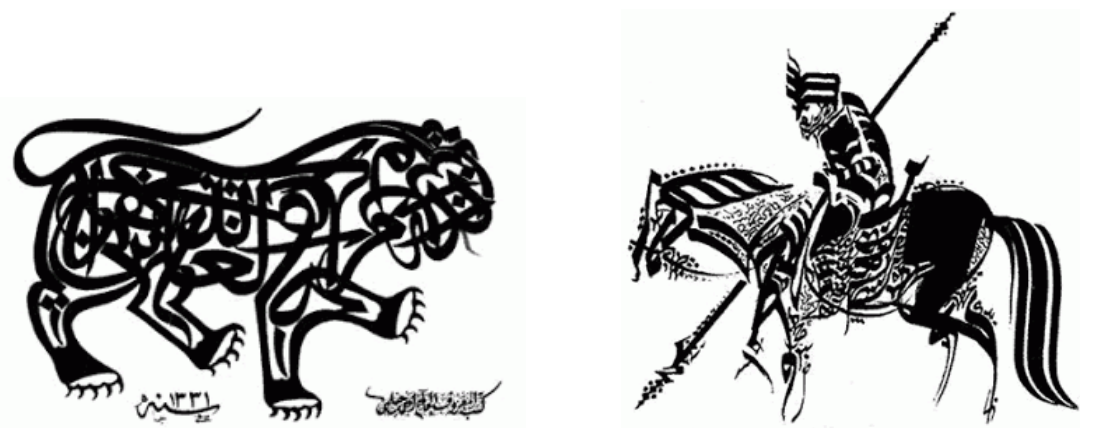

Figura 3. Códices islámicos.

Fuente: https://fratertempli.files.wordpress.com/2011/01/codicesislamicos2.gif

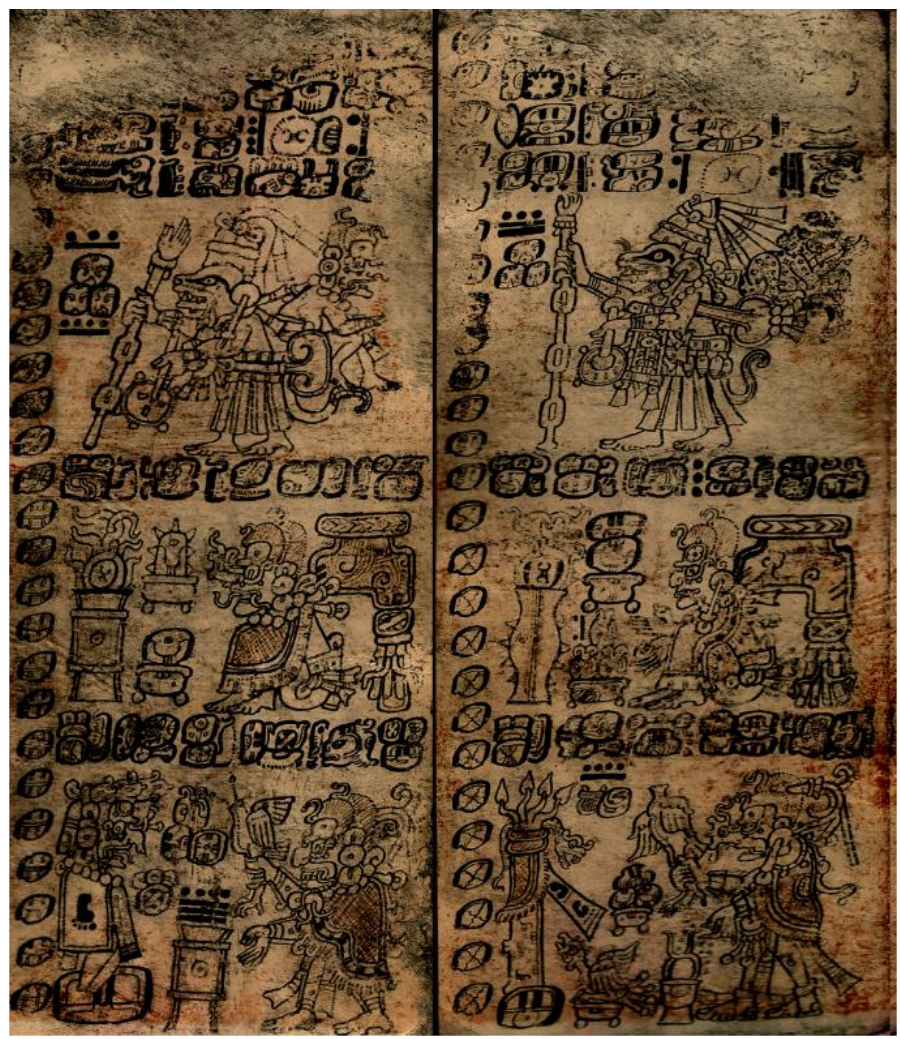

Figura 4. Imagen maya del Códice de Dresde, páginas 25-26.

Fuente: Reproducido por Gabrielle Vail de Förstemann, 1880. 
Después de Cristo, un interesante ejemplo es la columna de Trajano, que describe gráficamente dos campañas exitosas del Imperio romano en Dacia (101102 y 105-106). Hecha en mármol de carrara, fue finalizada en el año 113 d.C. y atribuida a Apolodoro de Damasco; tiene una altura de 30 metros, más 8 del pedestal, con 18 bloques con 4 metros de diámetro rodeados de una orla en espiral esculpida a bajorrelieve que presenta momentos de las dos victorias del emperador Marco Ulpio Trajano en las guerras dacias. La columna lleva más de 2.500 figuras esculpidas y la imagen del emperador está presente 50 veces: semejante a una línea editorial, como si un diario actual diera amplia cobertura al candidato político al que apoya; por eso, sus escenas con consideradas "obras de propaganda política permanente”. (Blázquez, 2005, p. 23).

La distribución de las imágenes, en un inicio completamente policromadas, tiene un orden histórico: la primera campaña, (años 101-102) es narrada en la mitad inferior; mientras que la segunda (105-106) se representa en la mitad superior. Ambas sub-historias están separadas por la personificación de la diosa de Victoria. Asimismo, la Columna Trajana es un ejemplo lejano de combinación texto-imagen: en su pedestal se encuentra, en latín, el texto que da cuenta a quién rinde homenaje esta edificación.

Los estudios hablan de "crónica" al referirse a las imágenes de esta columna. Cabe señalar que, además de las escenas de victorias bélicas también se encuentran hechos cotidianos de la vida en el campamento. Es por eso una importante fuente de información sobre el ejército romano; asimismo, si bien es bastante realista, es una manifestación de las creencias de la época, con representaciones metafóricas de sus deidades y otros como el río Danubio, que es representado por un anciano. 
“La Columna Trajana es el documento esencial para los sucesos de las guerras dácicas. Su realismo gráfico permite ver directamente a los soldados en acción, así como a los prisioneros, y representa un gran realismo en la expresión de los heridos y de los dacios al entregarse”. (Blázquez, 2005, p. 52).

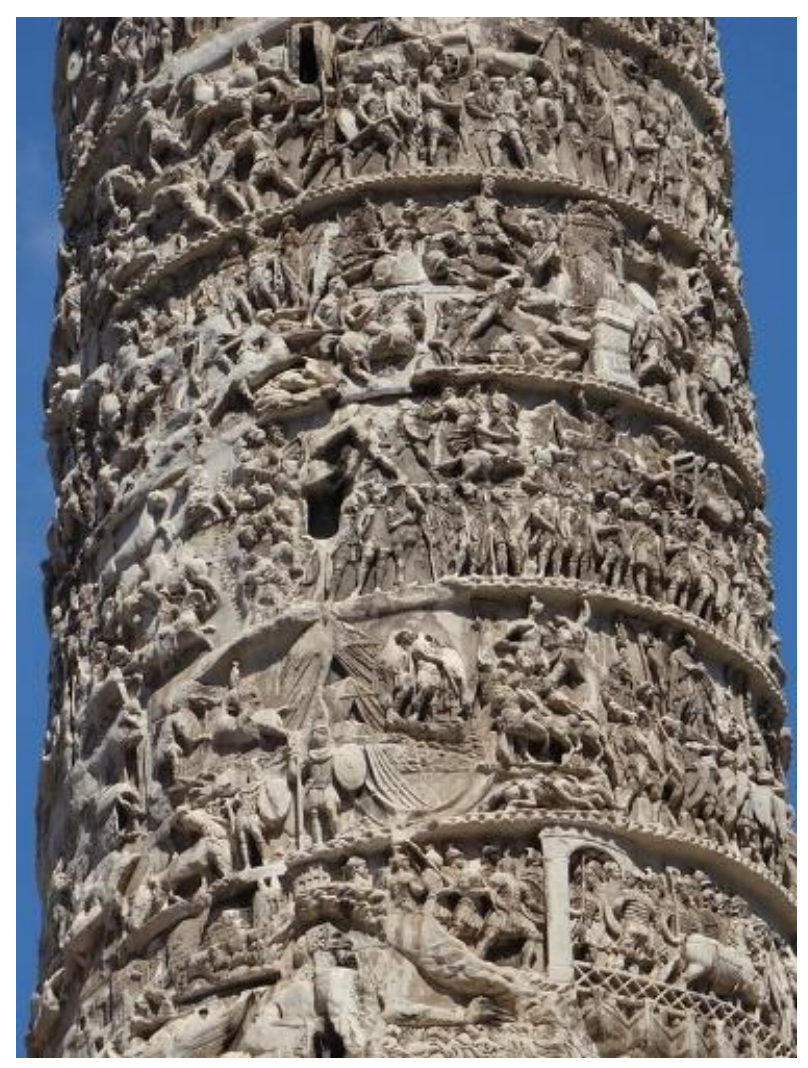

Figura 5. Detalle de la Columna de Trajano

Fuente: http://www.todocalidad.es/lugares-con-encanto/roma-la-columna-de-trajano/

Posteriormente, entre 176 y 172, se construyó la Columna de Marco Aurelio. Esta, que toma como inspiración a la columna Trajana, da cuenta de las victorias contra los germanos y los sármatas durante las guerras marco romanas; su construcción es un homenaje post mortem al emperador Marco Aurelio, quien lideró las mencionadas conquistas. Años después, durante una restauración, se creyó que fue hecha para el emperador Antonio Pío, por lo que ahora se conoce también como Columna Antonina. Un adelanto en las representaciones de esta 
edificación es la simplificación y esquematización de las formas, más destacadas del fondo y con un mejor manejo del volumen; asimismo, las figuras son más expresivas y dramáticas.

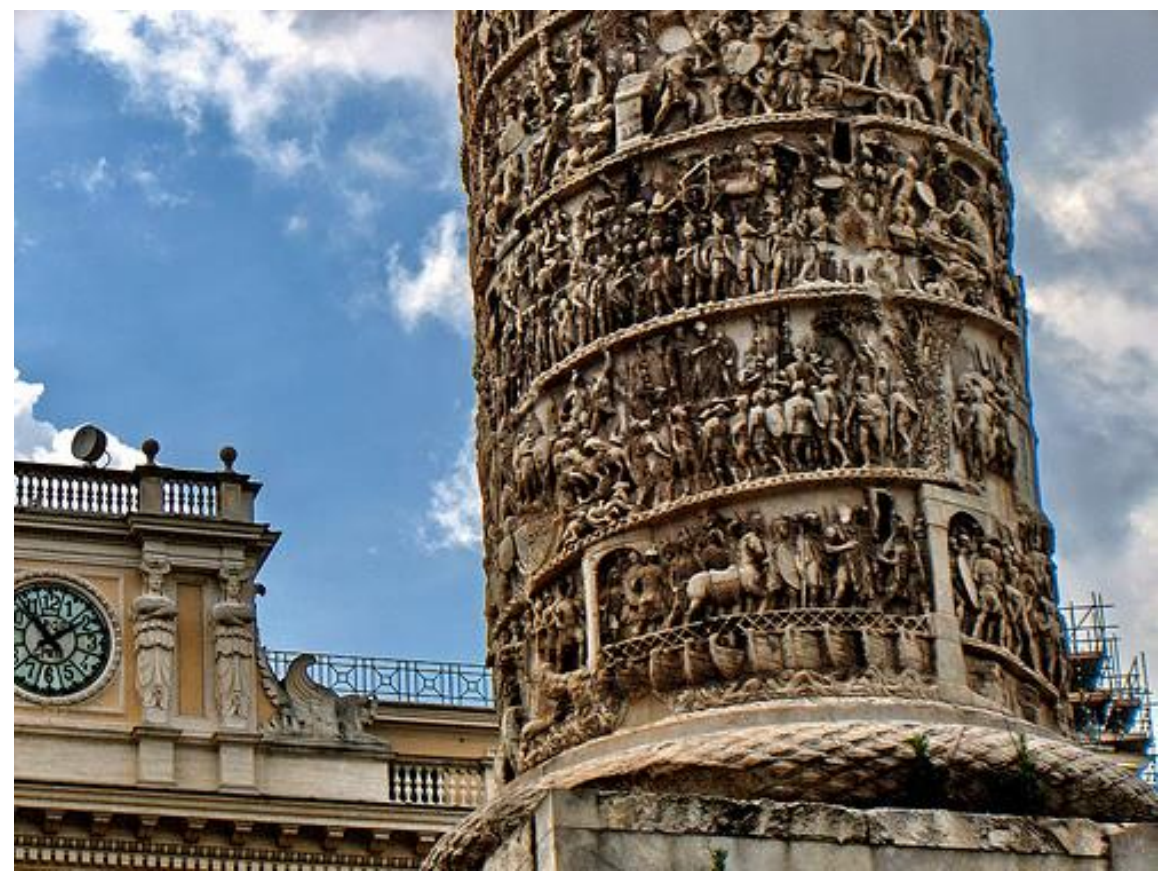

Figura 6. Detalle de la Columna de Marco Aurelio

Fuente: https://www.arkiplus.com/la-columna-de-marco-aurelio/

En la Edad Media se desarrollaron cuadros cuyas ilustraciones fueron hechas para contar historias, ya que fueron pensadas como elementos didácticos para un público analfabeto. Asimismo, significó el nacimiento del libro, en reemplazo a las hojas sueltas de pergamino.

Ejemplos majestuosos son los llamados "Manuscritos iluminados", compuestos por textos e ilustraciones que hoy en día son la más importante fuente de información visual sobre la vida en el medioevo. Plenos de imágenes, cabe destacar la capacidad de estas para narrar independientemente del texto; no se establecía aún una relación directa entre el contenido textual y la imagen, colocándose estas últimas libremente en las páginas. 
Las imágenes de estas producciones hablaban no sólo por las formas expuestas, sino también por el colorido y el brillante acabado que presentaban, logrado por las finas capas de oro y plata que se colocaba encima de ellas; por eso el nombre de "iluminados". (Méndez, 2010, p.112).

Rosa Gonzales cita diversos ejemplos, entre ellos los libros de horas, donde muchas veces las imágenes reemplazaban al texto. También señala un ejemplo de narraciones con imágenes en secuencia, como en el caso del "Comentario del libro de Daniel” de San Jerónimo, en el libro del Apocalipsis. Por lo expuesto, para esta autora, los manuscritos iluminados son una muestra de cómo "La ilustración se convierte en una obra narrativa pictórica autónoma”. (Gonzales, p. 14, s/a.)

Con la invención de la imprenta y la llegada del Renacimiento la relación entre imagen y texto fue adquiriendo una conexión más funcional en algunas representaciones, aunque abundan aún los ejemplos donde una imagen puede decir mucho sin nada o con poco texto.

\section{- ¿Cómic o novela gráfica? Cuestión de nombres.}

Existen ciertas confusiones y barreras que se cruzan en la definición de lo que es la tira cómica, el cómic, la historieta y la novela gráfica. Con respecto a su relación con el cómic o historieta, para algunos autores existen algunas distinciones entre ambas, mientras que para otros es lo mismo.

Así, Sergio Carrasco, citado por Evelyn Núñez, engloba bajo el término "historieta" tanto al cómic como a la novela gráfica (Núñez, 2010, p. 14). Pero José Manuel Trabado marca distancia entre tira cómica y comic book en relación a la novela gráfica, considerando como marcador de esta diferencia el espacio con 
el que se cuenta para presentar la historia: "Si la tira diaria, la página dominical y el comic-book podrían ser considerados como plantillas formales que encarcelan la trama argumental, la novela gráfica podría ser entendida como una liberación al considerar que es la historia en sí misma la que regula la forma y no ésta la que condiciona el desarrollo narrativo". (Trabado, 2012, p. 9).

Para la presente investigación se ha considerado pertinente partir del punto de vista de Mike Chinn y Chris McLoughlin, que señalan que lo único distinto entre el comic y la novela gráfica es la extensión: "No hay diferencia. O, por lo menos, tan sólo la misma que puede existir entre una novela convencional y un relato corto o una novella". (Chinn, 2009, p. 14).

Los mismos autores indican como característica de la novela gráfica el hecho de presentar una historia compleja con un personaje o grupo de personajes que son transformados durante el desarrollo del argumento y el final de la trama implica el fin de la historia; esta puede ser presentada en un solo documento o publicadas por partes, como Maus, de Art Spiegelman, cuyos capítulos se presentaron originalmente en la revista Raw, o Church + State, que por su extensión tuvo que presentarse en varios volúmenes de la serie de historietas Cerebus. Más adelante se tratará más a detalle lo concerniente a estas producciones.

Pero estos autores si hacen una diferenciación entre "novela gráfica" y "relato gráfico", arguyendo que la primera implica historias de tal profundidad que presentan una extensión de más de 30 páginas, y que, si bien ambos son cómic "no todos los cómics son novelas gráficas”. (Chinn, 2007, p. 15). 


\section{- $\quad$ Arte secuencial}

Es importante tanto la novela gráfica como el relato gráfico tienen en común la narración de tipo secuencial:

La organización de una secuencia de ilustraciones implica la utilización de elementos de diseño, tales como metáforas visuales, simbolismo, resonancia y reverberación para infundir emociones e ingenio. Algunas narraciones visuales, como, por ejemplo, las novelas de Frans Masereel, interpretan el texto sin usar tipografía, si bien muchas narraciones ilustradas también integran imágenes y tipografía. El tipo de letra, su espesor y su legibilidad deben ser los apropiados ya que tienen que armonizar con el espíritu de la historia, con el diseño global y con el ritmo y estilo de las ilustraciones. (Wigan, p. 18, 2007).

Fue Will Eisner quien acuño el término "arte secuencial”. El dibujante es reconocido por el intenso trabajo para que el cómic sea reconocido como arte, defendiendo su calidad literaria.

Para Eisner la narración gráfica reúne diversos géneros unidos por el concepto de "arte secuencial" o sucesión de imágenes que van contando una idea en secuencia. El cómic, la novela gráfica e incluso la infografía están contemplados en esta categorización. El "arte secuencial" fue considerado durante mucho tiempo como un medio artístico de menor calidad.

En general, y por motivos que tienen mucho que ver con la costumbre y la temática, el Arte Secuencial ha sido desdeñado, considerándosele indigno de serio debate. Mientras que sus principales elementos integrantes; a saber, 
la concepción, el dibujo, la caricatura y la escritura, han recibido consideración académica por separado, la combinación de todos ellos ha obtenido un lugar insignificante en el mundo literario y en el artístico. (Eisner, 1996, p.7)

Eisner es autor de Spirit publicado en 1940 y que, no obstante, las burlas y poca consideración que recibió en su momento, se convirtió en un clásico por su inusual uso de encuadres, iluminación y sombras, semejantes al cine y a su narrativa.

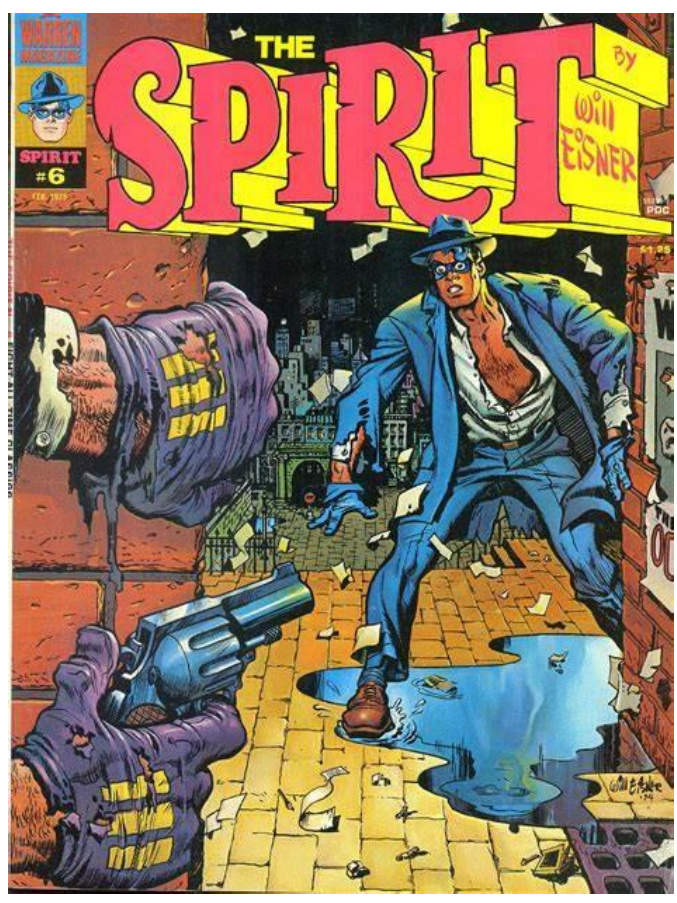

Figura 7. Portada de The Spirit de Will Eisner.

\section{- $\quad$ Exponentes internacionales de la novela gráfica}

A continuación, se listan algunos de los ejemplos más relevantes.

Contrato con Dios: Luego de haber alcanzado el reconocimiento y la fama por su inmenso aporte en el campo del cómic, Eisner publicó en 1978 Contrato 
con Dios, obra que narra cuatro historias que tienen como escenario la ciudad de Nueva York y están unidas por la tragedia: así, Contrato con Dios, que da título al libro, es la historia de un judío que pierde la fe luego de la muerte de su hija adoptiva, y que, aunque no es autobiográfico, se inspira en la experiencia similar por la que pasó el autor; en El Super el protagonista es un hombre racista que se suicida luego de una falsa acusación por pedofilia. En El cantante callejero y Cookalein las temáticas son crudas también. La importancia de esta producción reside en el empeño de Eisner en que fuera reconocida como una obra para un público adulto y se separara en estilo y contenido del mundo de las historietas. Al autor se le considera el "padre de la novela gráfica", y aunque cabe señalar que Contrato con Dios no fue la primera obra de este tipo en Estados Unidos: "Su enorme influencia en creadores posteriores, que querían rehuir de las típicas historias infantiles y de superhéroes tanto en términos de contenido como de formato, hace que podamos considerar el libro de Eisner, sin ningún tipo de exageración, como uno de los pilares del género". (Gamero, líneas 91-96).

Marea Roja (Red Tide): Publicada en 1976, la trama gira en torno a un detective (Chandler) que es contratado para resolver un envenenamiento. El autor declaró que hizo el libro en dos meses y medio como un favor a un amigo, cuando el tiempo requerido hubiera sido por lo menos de seis meses.

A diferencia de otras producciones de este tipo, la relación entre texto e imagen es indivisible, una no puede ser comprendida sin la otra. Tiene una inusual presentación de imágenes (dos por página) y texto en la parte inferior de cada ilustración. No presenta globos de texto como los cómics tradicionales. 
Precisamente por su estructura poco convencional no tuvo la acogida esperada en su lanzamiento, pero se ha convertido en un clásico de culto.
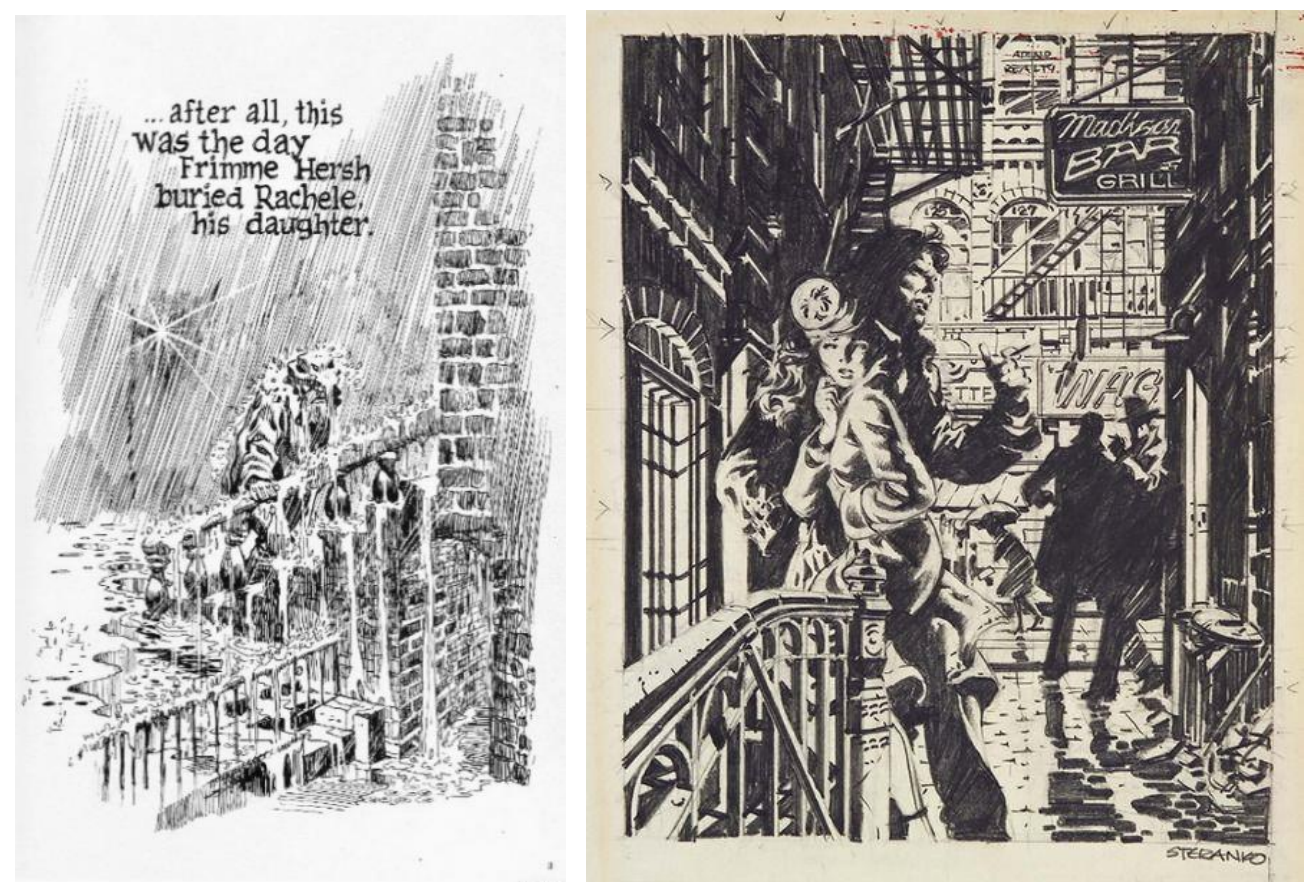

Figura 8 y figura 9. Contrato con Dios de Eisner y Marea Roja de Steranko.

Maus: Art Spiegelman, autor de esta novela gráfica, obtuvo en 1992 el

Premio Pulitzer por la obra, que presenta, a través de ratones, una historia de supervivencia en un campo de concentración nazi. Está conformada por dos partes, que fueron publicadas en la revista de cómics Raw, de propiedad de Spiegelman y su esposa Françoise Mouly, desde su fundación en 1980 hasta 1991, con un total de once ediciones. En 2007 fue editada, como libro, y traducida al español por Penguin Random House Grupo Editorial, S.A.U.

La trama narra la aterradora experiencia del padre del autor, Vladek Spiegelman, judío polaco que sobrevivió al exterminio: 
Apartándose de las formas de literatura creadas hasta la publicación de Mau, Art Spiegelman se aproxima al tema del Holocausto de un modo absolutamente renovador, y para ello relata la experiencia de su propia familia en forma de memoria gráfica, utilizando todos los recursos estilísticos y narrativos tradicionales de este género y, a la vez, inventando otros nuevos. La radicalidad narrativa de esta obra marcó un antes y un después en el universo de la novela gráfica... (Penguin, Random House, s/p).

Se presenta esta obra como referente por su interesante tratamiento en forma metafórica sobre una etapa cruel en la historia de la humanidad. En cuanto a la gráfica, llamó la atención el uso de viñetas más apiñadas y con un mayor uso de negro en la parte en que los ratones están en el campo de concentración, añadiendo dramatismo a la historia.
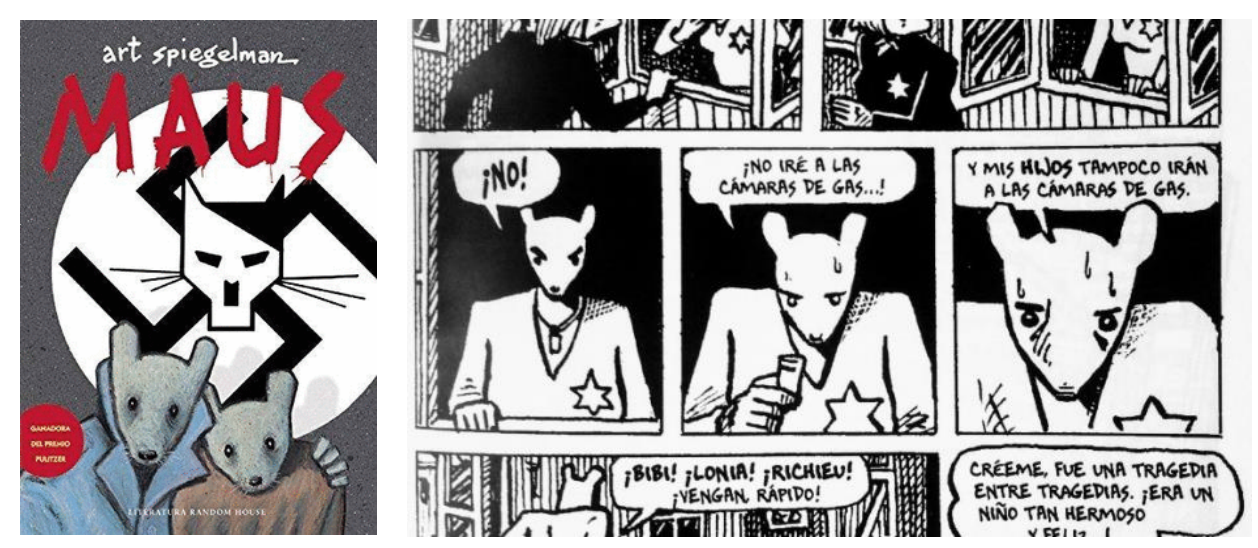

Figura 10. Portada y detalle de interiores de Maus.

Persépolis: realizada por la guionista e ilustradora Marjane Satrapi, esta novela gráfica cuenta su infancia en Teherán durante la Revolución iraní y su 
adolescencia y adultez en Europa, dando testimonio de su existencia en dos países con estilos de vida y filosofías contrapuestas, la oriental y la occidental. Fue llevada al cine como película animada dirigida por Satrapi y el director francés Vincent Paronnaud.

La película animada siguió el mismo estilo de la novela gráfica, en blanco y negro, solo se utilizó color en el tiempo presente; tras su estreno en 2007, ganó el Premio del Jurado en el Festival de Cannes ese mismo año, y en el 2008 el Premio César a la mejor ópera prima y a la mejor adaptación y diálogo, entre otros reconocimientos.

Se presenta esta obra como referente tanto por su temática sociocultural como por el uso de trazos sencillos y sintéticos, que en vez de restar interés añaden más fuerza expresiva a la historia, lo cual se ve reforzado con el tratamiento en blanco y negro.
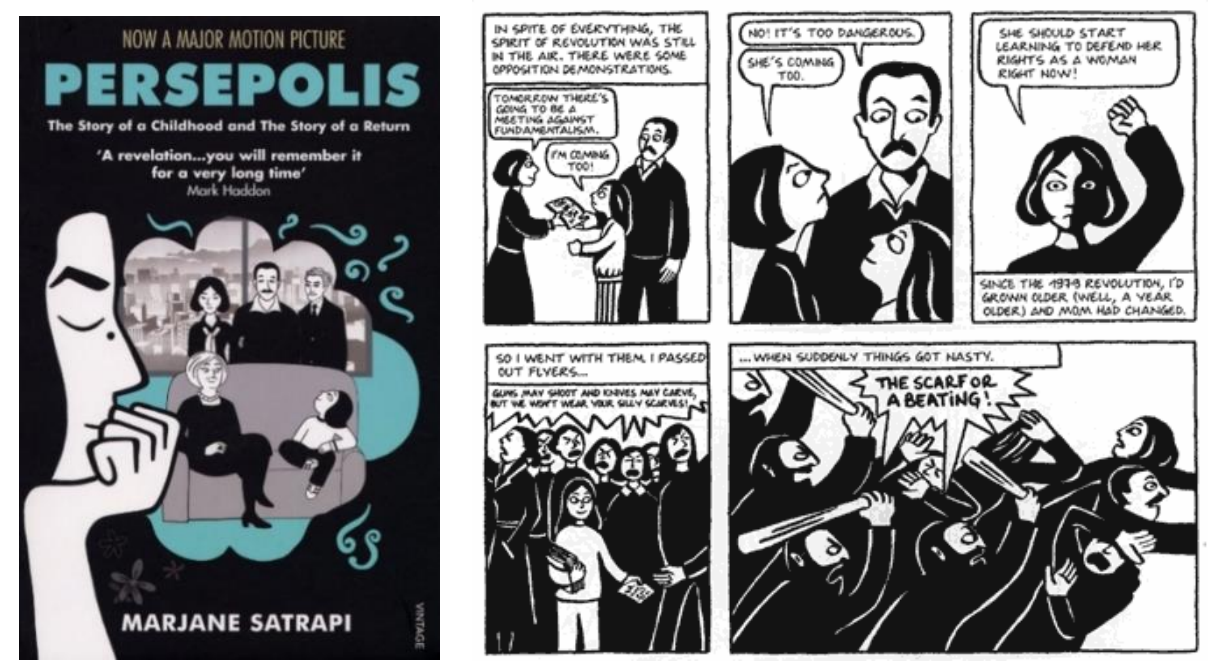

Figura 11. Portada y detalle de interiores de Persépolis.

Rides (Arrugas): Escrita en 2007, es la obra que le dio reconocimiento al español Francisco Martínez Roca, conocido como Paco Roca. Actualmente 
considerado el mejor narrador gráfico español del mundo contemporáneo, fue ilustrador y guionista de la historia.

La novela narra la amistad entre Emilio, quien padece de Alzheimer y Miguel en una residencia geriátrica. Fue realizada en honor a los padres del autor e inspirada también en la enfermedad que padecía el progenitor de uno de sus mejores amigos, además de haber observado, durante su experiencia en el campo publicitario, como los ancianos eran prácticamente invisibilizados del medio.

La obra recibió en 2007 dos premios en el XXVI Salón del Cómic de Barcelona: Mejor Guion de Autor Español y Mejor Obra de Autor Español; así como otros reconocimientos en 2008, entre ellos el Premio Nacional de Cómic.

En 2011 se estrenó la versión cinematográfica en el Festival Internacional de Cine de San Sebastián. Fue dirigida por Ignacio Ferraras.

Se decidió colocar esta obra como referente tanto por la manera en que el autor permite sentir la esencia de la obra tanto en la narrativa a través del texto e imágenes como en la paleta de color empleada.
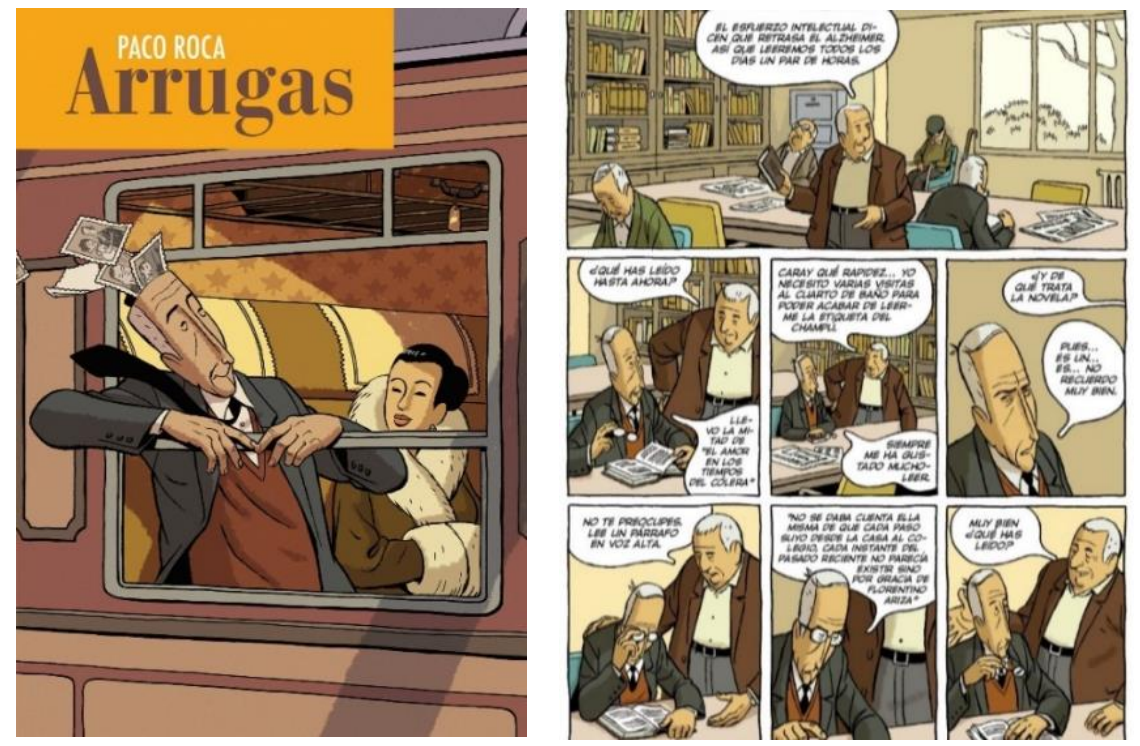

Figura 12. Portada y detalle de interiores de Arrugas. 
300: esta novela gráfica se publicó en cinco números en 1998; el guion y las ilustraciones estuvieron a cargo del reconocido dibujante Frank Miller; Lynn Varley colaboró en las colorización. La obra describe la batalla de las Termópilas, en la que 300 guerreros espartanos se enfrentan al ejército de Persia. Si bien tuvo muchas críticas relativas a su rigor histórico, la indumentaria de los personajes o los diálogos, en los Premios Eisner de 1999 recibió los laureles de Mejor Serie Limitada, Mejor Guionista/Dibujante y Mejor Color. Ese mismo año obtuvo el Premio a la Mejor Obra Extranjera en el Salón del Cómic de Barcelona.

En 2007 fue llevada a la gran pantalla por Zack Snyder. Fue rodada, con pequeños cambios, de manera muy similar a los cuadros planteados por Miller.

Se escogió esta obra como referente por el dinamismo gráfico de las representaciones y por el uso a doble página para el desarrollo de la narrativa.
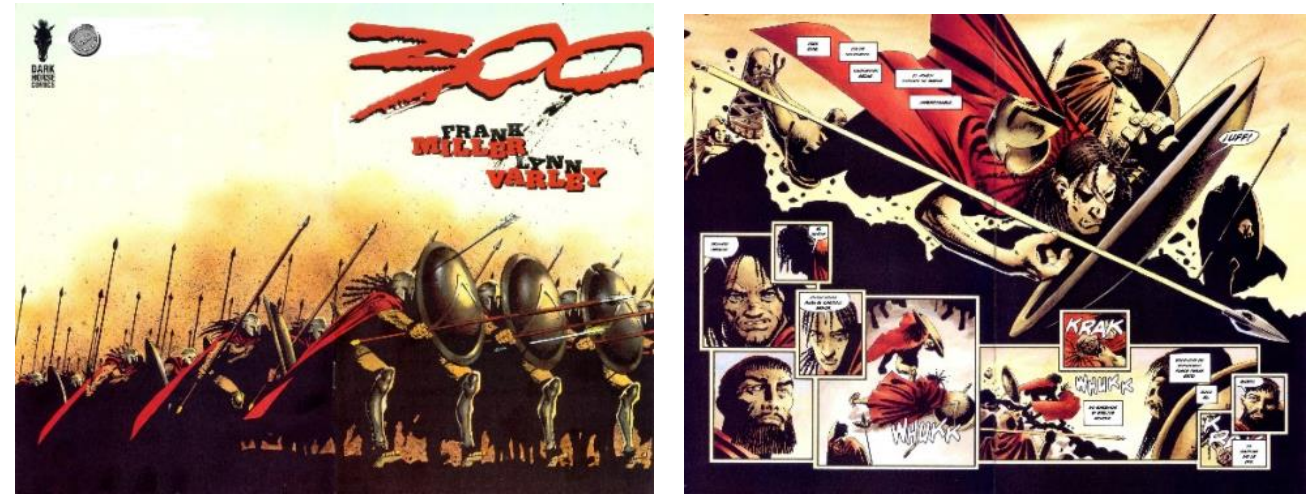

Figura 13. Pliego de portada y pliego interior de 300.

Ich: Naturaleza salvaje: Publicada en 2017 por los argentinos Ariel Olivetti (ilustrador, reconocido por su trayectoria en Marvel Comics) y Luciano Saracino (guionista), es una historia fantástica ambientada en la Selva amazónica peruana. El protagonista es Ich (“máscara"), quien tiene la facultad de presentarse con la forma de cualquier ser viviente, y utiliza este poder para enfrentarse a los 
invasores de su tierra (españoles). La obra ha recibido algunas críticas en torno al desarrollo de la historia, pero elogios en cuanto a la fuerza y color de las ilustraciones.

Aunque es catalogado como cómic más que como novela gráfica, fue tomada en consideración porque presenta una historia ambientada en la Selva Amazónica y en la época de la Conquista, como la solución gráfica que se planteará en esta investigación.
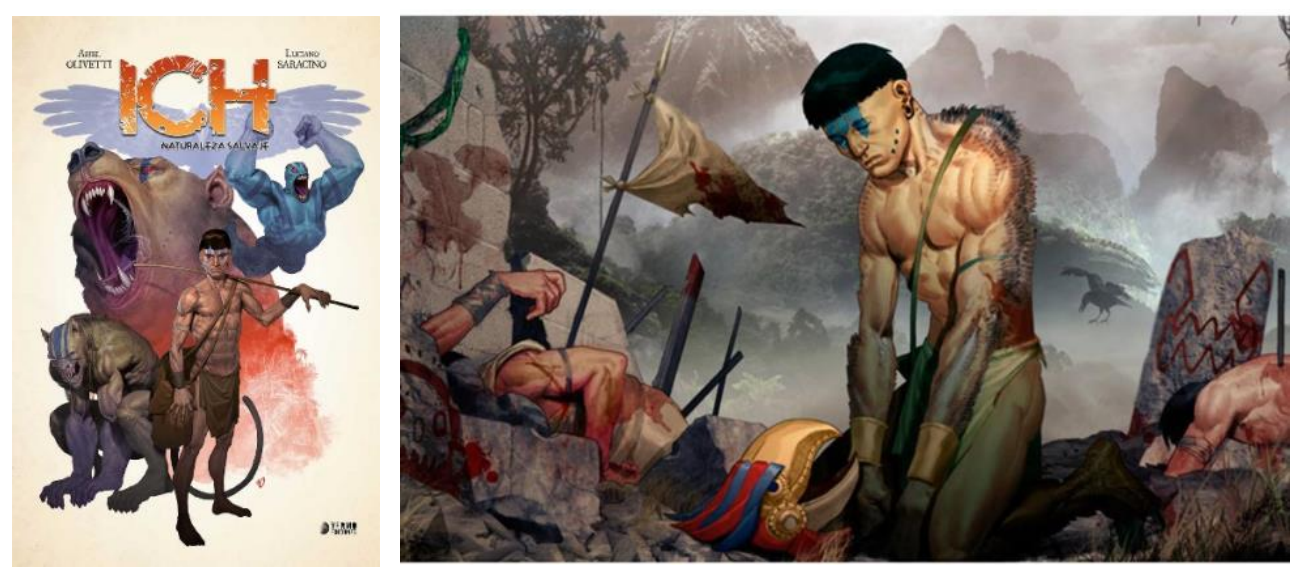

Figuras 14. Portada e ilustración interior de Ich naturaleza salvaje.

\section{- $\quad$ La narrativa gráfica en Perú}

La historia de las imágenes en Perú se remonta al tiempo de las culturas precolombinas, con los grandes exponentes de la cerámica como las culturas Nazca y Mochica, los textiles de los Paracas, el tallado en piedra de los Chavín, o la orfebrería de los Chimú, entre otras majestuosas obras que ilustran el medio ambiente o la cosmovisión de sus hacedores.

Pero estas piezas no narran hechos, solo momentos, ideas y formas de ver el mundo. Thomas Cummins señala que "la historia en el Perú fue recordada por los quipus y quipucamayocs, y no por las letras o pinturas". (Michaud, 2015, p. 44). El autor compara el recorrido de la imagen en Perú y en México, siendo la tierra 
azteca mucho más visual en el tema narrativo, con sus diversos códices, que la peruana, donde hubo un mayor predominio de la transmisión de relatos a través de la oralidad.

Con la llegada de los españoles los nativos de las tierras hoy peruanas se vieron precisados a asumir la forma de representación de la cultura occidental impuesta; el uso de la perspectiva al parecer no era conocido en el mundo andino. Cummins estudia las representaciones pictóricas en la época del Virreynato, que servían como pruebas y manifestaciones de testigos oculares en diversas causas judiciales y destaca el rol de la imagen para narrar. Muchas veces se daba crédito a lo representado en imágenes, pues daban fe de algún hecho, tal como hacían los textos escritos. Autores reconocidos de este periodo fueron Guamán Poma de Ayala, cronista de ascendencia incaica, con su historia: Nueva crónica y buen gobierno (1615); y el sacerdote español Martín de Murúa, quien escribió e ilustró Historia General del Perú. Origen y descendencia de los incas (sin fecha exacta). Según Cummins, Guamán Poma aprendió de Murúa, para quien trabajó, la importancia de las imágenes y la vinculación de estas con una historia creíble. (Michaud, 2015, p. 58).

La narrativa gráfica no contó con otros exponentes representativos hasta inicios del ciclo pasado con la publicación de la revista de humor político Monos y monadas en 1905. Relanzada en 1978, tuvo entre sus dibujantes a Juan Acevedo y Carlos Tovar (Carlín). Personaje importante del mundo gráfico fue también Julio Fairlie, creador de Sampietri, personaje que retrata al limeño criollo y vivo; el historietista arequipeño dio vida también a otros icónicos personajes del humor gráfico peruano como: Vicuñín, Manyute, el Super Cholo o el Capitán Intrépido. 
Seguidamente se presentan tres referentes del campo de la novela gráfica peruana:

Selva misteriosa. Fue publicada en un inicio en las páginas del diario El Comercio, desde el 1 de noviembre de 1971 hasta el 4 de octubre de 1974. Con las historias de Javico, un trochero, presenta una visión realista de distintos ángulos de la selva amazónica peruana, sus habitantes, fauna y problemáticas. La publicación fue abruptamente interrumpida con la expropiación de la prensa durante la dictadura militar de Velasco Alvarado, al considerarse al cómic como un medio alienante.

El guionista y dibujante fue Javier Flórez del Águila, quien comenzó en el mundo del cómic en 1954 en la revista Avanzada, con series como Capitán Alas y El misterioso señor Psiq; en ese entonces, era estudiante de medicina. En 1971, ejerciendo ya como médico, ganó con Selva misteriosa un concurso de historietas convocado por el diario El Comercio.

En la recopilación publicada por Planeta Cómic (2019), Enrique Planas la señala como "la mejor novela gráfica de aventuras (novela río, podríamos decir) hecha en el Perú”. Asimismo, indica que "Quien quiera leer Selva misteriosa también como documento histórico, encontrará el proyecto de un autor que busca reflejar el movimiento civil de entonces, resistente al gobierno militar y a su reforma agraria". (p. 12). Es entonces, una historia que entretiene, pero que funge a la vez como denuncia social.

Estos son los títulos de las historias de la recopilación: El finado, El otorongo, Lindos ojos, Ella, Campo de amapolas, El único superviviente, Pushanga, Noela, La denuncia, Agente encubierto. Tres de ellos con directa 
vinculación con la selva peruana. No obstante, parte del éxito de las narraciones se atribuye al uso de lenguaje típico de la zona, tanto en la narración como en la voz de los personajes, lo que generó una conexión adicional, una mayor fuerza regional como indica Juan Acevedo en la mencionada recopilación. (Planeta Cómic, 2019, p. 11).

Finalmente, el mismo Flórez del Águila señala que sus referentes en cuanto a gráfica fueron Jim Steranko (estadounidense), Sergio Toppi (italiano) y Enric Sió (catalán), además de Andy Warhol y el pop art.
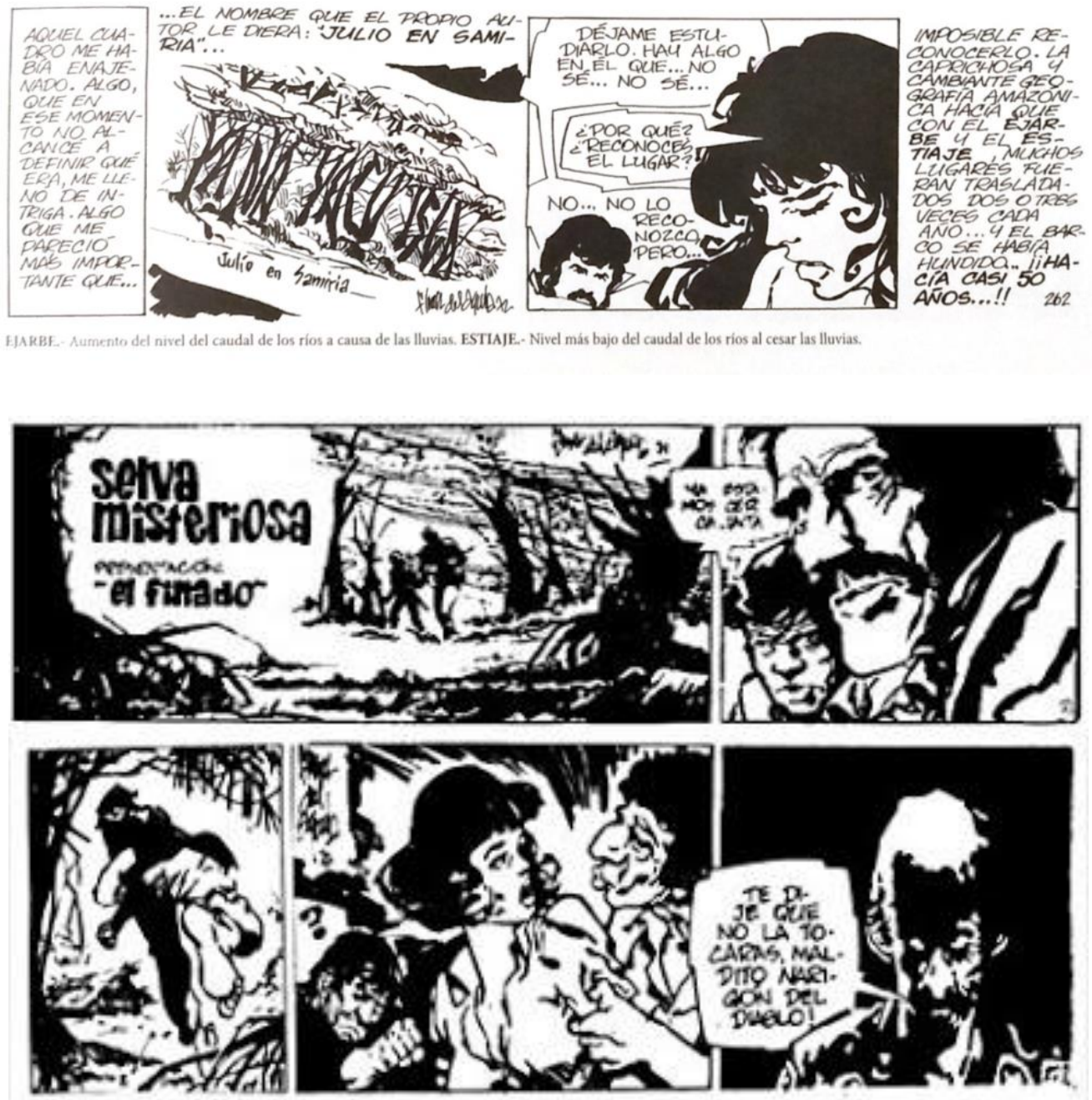

Figura 15. Detalles de interiores de recopilación de Selva misteriosa. 
Ciudad de payasos. Esta novela gráfica, publicada en 2010, fue originalmente un cuento en la revista The New Yorker en 2003. Escrita por Daniel Alarcón e ilustrada por Sheila Alvarado, narra la historia del periodista Óscar, "Chino", quien tras la muerte de su padre recibe la comisión de escribir un artículo sobre payasos. El protagonista se disfraza de payaso y a través de esta máscara, que lo protege y lo esconde del desamparo de la ciudad de Lima, observa las diferentes facetas de la ciudad y realiza un viaje introspectivo hacia su infancia humilde.

Aun cuando en la versión grafica el texto es bastante similar al original, las ilustraciones añaden fuerza expresiva. Para Vich, estas imágenes cumplen un rol no solamente ilustrativo, sino que son parte importante de la historia, su papel traspasa el rol de complemento del texto: “...el aspecto gráfico es lo que magnifica el aspecto de un imaginario tenebroso y siniestro, presentándolo como elemento distintivo e idiosincrático del espacio social limeño". (Michaud, 2015, p. 284).

En 2009 se realizó el corto Payasos, inspirado en el cuento de Alarcón. Dirigido por Marianela Vega Orozae, fue galardonado como el Mejor cortometraje CONACINE 2010, y por Mejor ficción y mejor cortometraje FILMOCORTO en el Festival de Cine de Lima 2009. Aquí, los personajes y los escenarios son reemplazados por seres reales, con lo cual la narrativa adquiere otra dimensión. Así, como señala Morales:

...el texto de Alarcón se transforma y reinventa al adaptarse y nutrirse de las posibilidades expresivas que le dan distintas formas artísticas. Carlos Scolari habla de fenómenos transversales en los que se desarrolla la misma 
historia en diferentes medios... lo cual les otorga un sentido diferente. En Ciudad de payasos podemos ver un fenómeno similar, la maleabilidad del texto favorece que mute, que adopte nuevas formas. De ahí que la historia no sea la misma en el cuento, en la novela gráfica o en el cortometraje, cada medio hace un aporte a la construcción del mundo narrativo. Todas son formas de narrar una historia que ofrecen al lector una experiencia de significación diferente. (Morales, 2016, líneas 100-105).
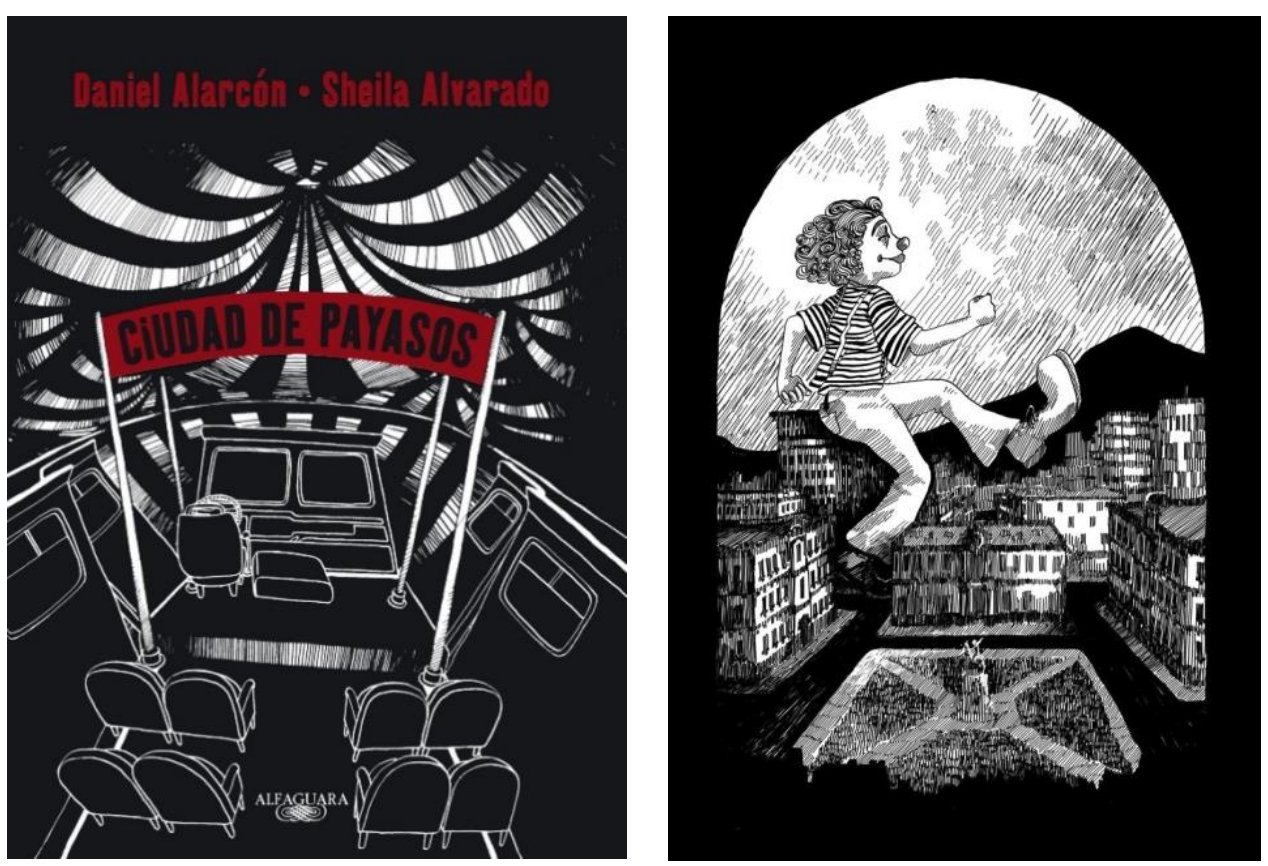

Figura 16. Portada y detalle de interiores de Ciudad de payasos.

Ayar. La leyenda de los Inkas. Realizado por Tawa Producciones, equipo integrado por Óscar Barriga, Virginia Borja, Kalmer Dolmos y Erly Almanza, la historia presenta la leyenda andina que explica la fundación del Imperio incaico, combinando la narración con la mitología de la Costa, Sierra y Selva del Perú. "El contenido está enriquecido por leyendas y mitos que no son adulterados, pero al ser insertados en este fantástico mundo logra no solo un impacto en la ficción 
fantástica, sino también en la cultura de las raíces ancestrales incas". (Tawa, 2018, p. 4).

Con un inicio en 2011 como vendedores ambulantes, rápidamente ganaron las preferencias de un público lector de Arequipa, su lugar de origen. En 2012 se presentaron en el Comic Con de San Diego (Estados Unidos) y tuvo buena acogida en el mercado internacional; en 2014, la obra se exhibió en Frankfurt, Alemania, en una feria del libro. En 2018 los tres números de la historia se juntaron en una sola publicación, editada por Planeta Cómic, con un tiraje de 3000 ejemplares.
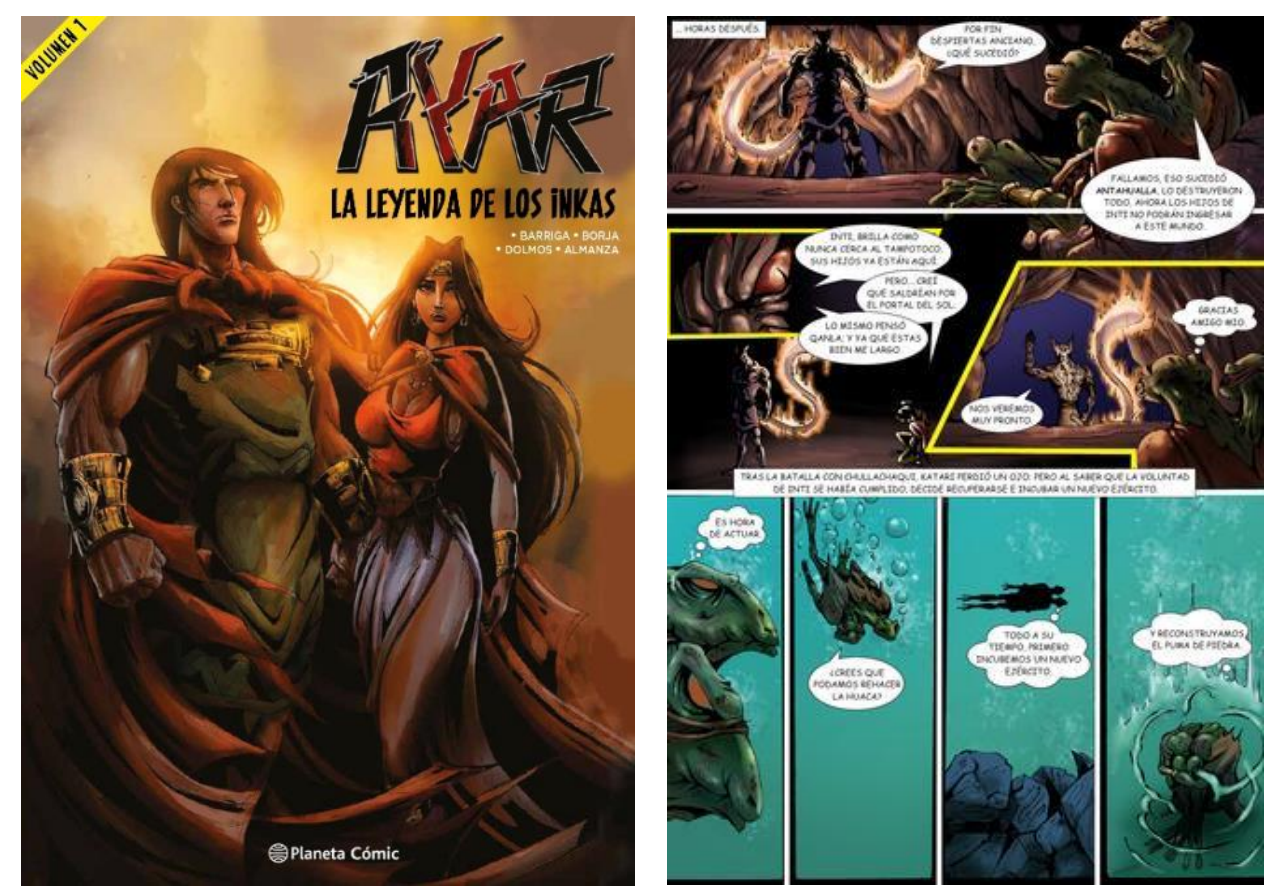

Figura 17: Portada y detalle de interiores de Ayar. La leyenda de los Inkas.

\section{- $\quad$ Aporte educativo de la narración gráfica}

La imagen como elemento comunicativo presenta ventajas respecto al texto que es lo que explota la narrativa visual. La percepción icónica, término utilizado por Joan Costa respecto al acercamiento del ojo a la imagen figurativa es parte del 
llamado "placer del ojo", que se deleita con la imagen tanto por su carácter estético como por lo relativamente sencillo que es comprender su significado si se compara con el de un texto, que requiere un aprendizaje previo de códigos abstractos (y que, precisamente por esto otorga otro tipo de placer, el “intelectual”). En síntesis, el lenguaje visual es de fácil penetración pues implica menos esfuerzo.

Acercarse a una imagen brinda una libertad que no es posible en la lectura de un texto. Lo primero puede hacerse sin restricciones, no hay ningún punto de partida obligatorio para ver una imagen. Pero un texto implica una lectura secuencial y lineal, que en Occidente va de izquierda a derecha.

En la historieta (y por extensión, en la novela gráfica), encontramos los dos tipos de elementos; pero hay predominio de la imagen versus el texto. No se le resta valor, no obstante, a este último. Pero, si se observan las historietas actuales se verá que hay cada vez menos texto. "Es importante que un dibujante de cómics pueda comunicar sin necesidad de globos de diálogo" señaló German Peralta (2019), dibujante argentino de Marvel Comic en una charla realizada en la Universidad de Lima. Lo cual no quiere decir que no haya nada de texto, sino más bien que en lo posible la imagen debe ser lo suficientemente expresiva para poder prescindir del texto. Este debe complementarla, no completarla.

Esta característica visual de la historieta la convierte en una alternativa para llevar más fácilmente un mensaje. Además, su carácter informal facilita la cercanía con el lector y la creación de vínculos afectivos: "El cómic permite una entrada sistémica al conocimiento, invita a compartir y puede generar relaciones de cooperación y de colaboración entre sus lectores". (Arango, Gómez y Gómez, 2009, p. 29). 
Como señala García (2010), citando a Herrador y Osorio:

...los tebeos constituyen un recurso muy interesante para el entretenimiento de niños y jóvenes. Su magia, su fantasía y su humor tienen tal capacidad de penetración en la imaginación de los escolares que las historias que cuentan y los personajes que los habitan forman parte de la vida de los lectores, creándose relaciones socioafectivas estrechas... (p. 132).

Por otro lado, la historieta presenta una ventaja que no cuentan el cine y otro tipo de imágenes móviles. Y es que, si bien no presenta el movimiento, las imágenes estáticas permiten una visualización durante el tiempo que se desee y desde el ángulo que se prefiera, abriendo más posibilidades para la comprensión del mensaje. Por eso, el "el cómic se manifiesta como una excelente mediación para la enseñanza en cualquier nivel de escolaridad”. (Arango, Gómez y Gómez, 2009, p. 29).

La información expuesta ofrece un acercamiento a las distintas realidades que contempla la solución de diseño que se presentará en el capítulo II: una novela gráfica. Primero, la riqueza cultural de la Selva Amazónica; segundo, las grandes posibilidades para llevar información y contar historias a través de la visualidad de la narrativa gráfica; y tercero, las características del público objetivo, joven, acostumbrado a la inmediatez y a la abundancia de información, cuyo interés tiene que ser capturado. También se consideró, entre las posibilidades, una solución audiovisual; sin embargo, se optó por la alternativa de la imagen estática y no en movimiento porque, de acuerdo a lo señalado en los párrafos precedentes, la estaticidad permite un recorrido visual más 
pausado y sin límites de tiempo, además de la relectura del contenido, lo cual incide positivamente cuando se trata de información compleja como la planteada.

\subsection{Estado del arte}

A nivel de investigaciones teóricas peruanas se registran diversas tesis, entre ellas cabe señalar: Cuerpos y territorialidad del pueblo Kukama en la política contemporánea sobre la Amazonía, elaborada por Marco Arturo Ramírez Colombier para optar el grado de Magister en Antropología por la Pontificia Universidad Católica

del Perú (PUCP). La tesis presenta un acercamiento al pensamiento indígena Kukama sobre su territorio, considerando su cosmovisión, las experiencias de sus moradores y las relaciones que establecen tanto con agentes humanos y no humanos (considerando las creencias ancestrales, que otorga vida a través del mito y la cosmovisión a otros seres vivos. Es un ejemplo de un estudio que considera el respeto a la diversidad y a las creencias indígenas, aún si son diferentes a las occidentales.

Otra tesis a citar, también en el campo de la antropología, es El reforzamiento de la etnicidad shipibo-konibo de las niñas y los niños de la comunidad Bena Jema por influencia de la educación intercultural bilingüe, de Jorge Manuel Quispe Díaz. Presentada en 2018 en la PUCP, este proyecto considera la importancia de reconocer las características propias de una cultura para empoderarla y permitir su desarrollo sin que se pierdan sus costumbres y tradiciones.

En el campo de la narración está la tesis de Evelyn Núñez Alayo, también de la PUCP, titulada "Novela gráfica peruana". La autora presenta un panorama de la novela gráfica en el Perú, centrándose en el caso de "Paco Yunque" de Juan Acevedo.

En la Universidad de Barcelona, Facultad de Filosofía, se presentó en el Bienio 1995 - 1997 la tesis doctoral Mito y chamanismo: el mito de la Tierra sin Mal en los 
Tupí-Cocama de la Amazonía peruana, del doctorando Juan Carlos Ochoa Abaurre, quien se insertó en una de las comunidades con el objetivo de estudiar el papel del mito en esta sociedad, y establece una interesante relación entre los mitos de diferentes culturas sobre el Paraíso, entre ellas la egipcia, la griega y la chamánica, entre otras. Esta asociación permite observar la universalidad del mito y el rol que ha cumplido y cumple en el desarrollo de las diversas sociedades.

Como referentes internacionales de la novela gráfica figura el libro de Will Eisner: El cómic y el arte secuencial, donde fundamenta la estética de este modo de expresión, tanto a nivel de lectura, la imagen, el ritmo, la viñeta, la anatomía expresiva, la escritura y la aplicación. 


\section{Capítulo II}

\subsection{Análisis del público objetivo}

La solución de diseño fue pensada para universitarios de la Facultad de Comunicación de la Universidad de Lima. Esta cuenta con aproximadamente 3,500 alumnos matriculados; de este grupo, 500 estudian otras carreras y llevan cursos de comunicación en paralelo; 3,000 se forman específicamente para ser comunicadores.

En los primeros años de la carrera (tercero, cuarto y quinto ciclo) hay más población en los cursos porque la mayoría de ellos son obligatorios; luego, los alumnos se van dispersando de acuerdo a las distintas especialidades que brinda la mencionada Facultad: Artes Visuales, Comunicación Corporativa, Comunicación para el Desarrollo, Gestión y Realización Audiovisual, Publicidad y Marketing, Periodismo y Gestión de la Información, y Videojuegos y Aplicaciones. Para egresar, el alumno debe completar un total de 210 créditos; la malla curricular es naturaleza flexible, lo cual implica que el estudiante puede optar por completar todos los cursos de una determinada especialidad, lo cual lo haría acreedor a un diploma, o llevar los cursos de su interés de cada una de estas hasta completar los créditos necesarios para terminar la carrera.

Entre las materias los alumnos reciben diversos cursos con una mirada hacia su entorno. En Estudios Generales llevan las asignaturas de Arte y Cultura, Globalización y Realidad Nacional, y Procesos Sociales y Políticos; mientras que en Facultad se forman en Análisis de Actualidad Nacional, Comunicación y Desarrollo, Sociedad y Comunicación, Procesos Interculturales, Educación y Comunicación. Pero ninguno de estos cursos se dedica un 100\% del tiempo a la visión de la problemática de la Selva. Asimismo, aunque la especialidad de Comunicación para el Desarrollo brinda materias que se enfocan específicamente a este campo formación, las problemáticas del país son vastas y el tema de la 
Selva debe ser tratado entre muchos otros. Así, si bien hay proyectos de comunicación interesantes cuyo campo de investigación es alguna etnia de la Amazonía peruana, la visión con la que egresa la mayoría de alumnos respecto a esta realidad es general. Como se sustentó según los resultados de la encuesta presentada en el punto 3.2 del Marco Teórico, conocen muy poco de la Selva tanto a nivel de territorio como en lo que respecta a culturas y cosmovisiones,

Del actor analizado (estudiantes de 17 a 23 años de edad), se ha seleccionado como público principal a los jóvenes de los primeros ciclos (tercero, cuarto y quinto), que tienen entre 17 y 20 años de edad. El objetivo de esta especificación es que, desde los primeros años de la carrera tengan un mejor acercamiento a la realidad de la Selva Amazónica. Es un grupo muy joven, en el primer y segundo año de carrera (sin contar el año de Estudios Generales) y es importante que, como futuros actores del cambio, cuenten con referentes diversos sobre la pluriculturalidad del país.

Los jóvenes de este sector pertenecen a la Generación Z, que fue revisada en el punto f. del Marco Teórico. En resumen, son jóvenes hiperconectados, multitasking (presentan poca capacidad para hacer una sola cosa al mismo tiempo), independientes e interesados en temas de responsabilidad social. Si bien son individualistas, cuando conocen una realidad o situación problemática es posible que participen y la hagan viral a través de las redes sociales. Asimismo, al haber crecido en un mundo digital y muy visual, prefieren la imagen a la escritura de textos largos, muestra de lo cual es el despunte de redes sociales como Instagram y el desarrollo de canales Youtube. Estas redes reflejan otra característica importante de este grupo objetivo: la inmediatez; lo cual se observa en la transmisión de videos cada vez más cortos, entre 15 segundos a 2 minutos.

Un punto de interés es que los integrantes de la generación $\mathrm{Z}$ tienen un espíritu viajero. En un estudio realizado por Booking.com, con más de 22,000 participantes, se observa que el 
$55 \%$ tiene como objetivo visitar por lo menos tres continentes distintos en un periodo de 100 años; y el 58\% busca aventuras en lugares remotos para la realización de senderismo, puenting o parapente. (La Vanguardia, 2019). En ese sentido, si bien no se busca promover en primera instancia el turismo, estos datos muestran una característica importante del público objetivo: las ansias de aventura y de descubrir cosas nuevas e interesantes. Sumado al hecho de que se preocupan por una sociedad justa e igualitaria, posibilita que puedan interesarse en otras realidades, distintas, si las descubren y conocen.

\subsection{Descripción del proyecto de diseño}

Para apoyar en el proceso de toma de conciencia sobre la pluriculturalidad, se ha propuesto una novela gráfica digital donde se dan a conocer mitos y leyendas de la cultura Kukama Kukamiria.

El hechicero es el capítulo 1 del libro inédito El misionero y la mujer del hechicero de Raúl Villacorta Vigo. La historia es ficticia, inspirada en hechos reales ocurridos hace más de 350 años en la selva amazónica. En la narrativa discurren una serie de mitos y leyendas propios de las distintas cosmovisiones de las etnias que en ella confluyen. El punto de partida es el pueblo Kukama Kukamiria, ubicado a orillas del río Ucayali. El capítulo elegido cuenta la historia del nacimiento del ser esperado que llevaría a los Kukama Kukamiria a la "Tierra sin mal", lugar muy importante para diversas etnias amazónicas emparentadas con los Tupíguaraníes.

Dado que en la investigación realizada se detectó un conocimiento limitado y sesgado tanto del territorio como de las culturas amazónicas, no obstante su infinidad de mitos, saberes y tradiciones; en la encuesta realizada solo algunos personajes mitológicos de la Selva son conocidos por una mayoría, como Tunche, Chullachaqui y Bufeo Colorado, como 
solución al problema detectado el producto final pretende presentar la heterogeneidad de la Selva Amazónica, centrándose en el caso Kukama Kukamiria, una etnia poco conocida. De esta manera, se busca ampliar el acervo cultural del público objetivo y colaborar para que se formen como profesionales conscientes de la pluriculturalidad y riqueza del Perú, fortalecer la identidad nacional y abrir una posibilidad para que, en un futuro, durante el ejercicio de sus funciones, puedan considerar el planteamiento de soluciones de comunicación que consideren las distintas realidades del país y las problemáticas de la Amazonía.

Ante el proyecto se espera una respuesta positiva y la viralización de la solución de diseño a través de las redes sociales. Como se señaló, una de las características de la Generación $\mathrm{Z}$ es que si son informados suelen interesarse en las problemáticas de corte social del país.

El concepto utilizado es "Descubrir para valorar”. El primer fascículo de la novela gráfica se difundirá a través de las redes sociales, Facebook e Instagram.

\section{- Articulación del proyecto}

Los pasos realizados para articular el proyecto se listan a continuación.

- En Lima: Entrevista a los conocedores de las culturas amazónicas y promotores culturales, como Sonaly Tuesta Altamirano, nacida en Lámud (Luya-Amazonas), conductora del programa Costumbres y "Personalidad Meritoria de la Cultura", título que recibió del Ministerio de Cultura en marzo del 2015. Contacto con Pablo Taricuarima Paima, kukama de nacimiento y promotor de su cultura de origen.

- Viaje a una comunidad Kukama Kukamiria para el trabajo de campo. Coordinación con el equipo que se encargó de la fotografía y del video. Realización de entrevistas a los pobladores: Pablo Taricuarima padre, Pablo Taricuarima hijo, señora 
Ruth Palma, en el pueblo de Santo Tomás; señora Ema Tapullima en la comunidad de Puerto Prado. Visita a la comunidad de Padre Cocha y a la ciudad de Nauta.

- Guionización de la historia, definición de personajes, planteamiento de las escenas, primeros bocetos, diagramación.

\section{- $\quad$ Partes o etapas}

- Levantamiento de información (trabajo de campo).

- Guionización del primer capítulo: El hechicero.

- Realización de las ilustraciones y diseño de la novela gráfica.

- Evaluación por pares.

- Levantamiento del libro en línea.

- Difusión a través de redes sociales.

\subsection{Proceso del proyecto}

\section{- Concepto del proyecto}

De acuerdo a lo sustentado en el marco teórico, la Selva es un lugar poco conocido. Lo poco que se conoce ha llegado a ser exotizado e incluso poco respetado. Se llegó a la conclusión de que solo se valora lo que se conoce; ese es el punto de partida del presente proyecto, cuyo concepto es "Descubrir para valorar".

El concepto surge del recorrido de diversas ideas relacionadas al término conocer, como las que se listan a continuación:

1. Motivar acciones de apoyo y desarrollo.

2. Promover el acercamiento a la realidad nacional.

3. Acercar al conocimiento de cosmovisiones distintas. 
4. Descubrir una sabiduría ancestral. Sabiduría que está llena de misterios en el caso de la Selva.

5. Respetar y tolerar la diferencia.

6. Fortalecer la identidad nacional.

7. Fortalecer el patrimonio cultural.

Este recorrido puede apreciarse en la figura 18. La figura 19 muestra las palabras que se asocian con el concepto y la figura 20 la visualización del concepto en imágenes.

\section{- Nombre del proyecto}

El nombre de la marca es "Sonidos del río" que hace referencia a la importancia del agua y de los ríos en la Selva amazónica. Adicionalmente, el agua, para este primer proyecto, es fundamental pues es parte esencial de la cosmovisión Kukama Kukamiria y de su estilo de vida, ya que son conocidos como "los grandes pesqueros" y muchos mitos giran en torno a ella. No en vano el río Amazonas es el más caudaloso del mundo.

\section{- Fundamentación del proyecto}

"Sonidos del río" son una serie de libros ilustrados estilo novela gráfica que presentan historias que se llevan a cabo en la Selva amazónica y que ponen en relieve la riqueza cultural y diversa de las diferentes culturas de la zona. El proyecto consiste en el lanzamiento del capítulo 1 del libro El misionero y la mujer del hechicero, titulado El hechicero. 


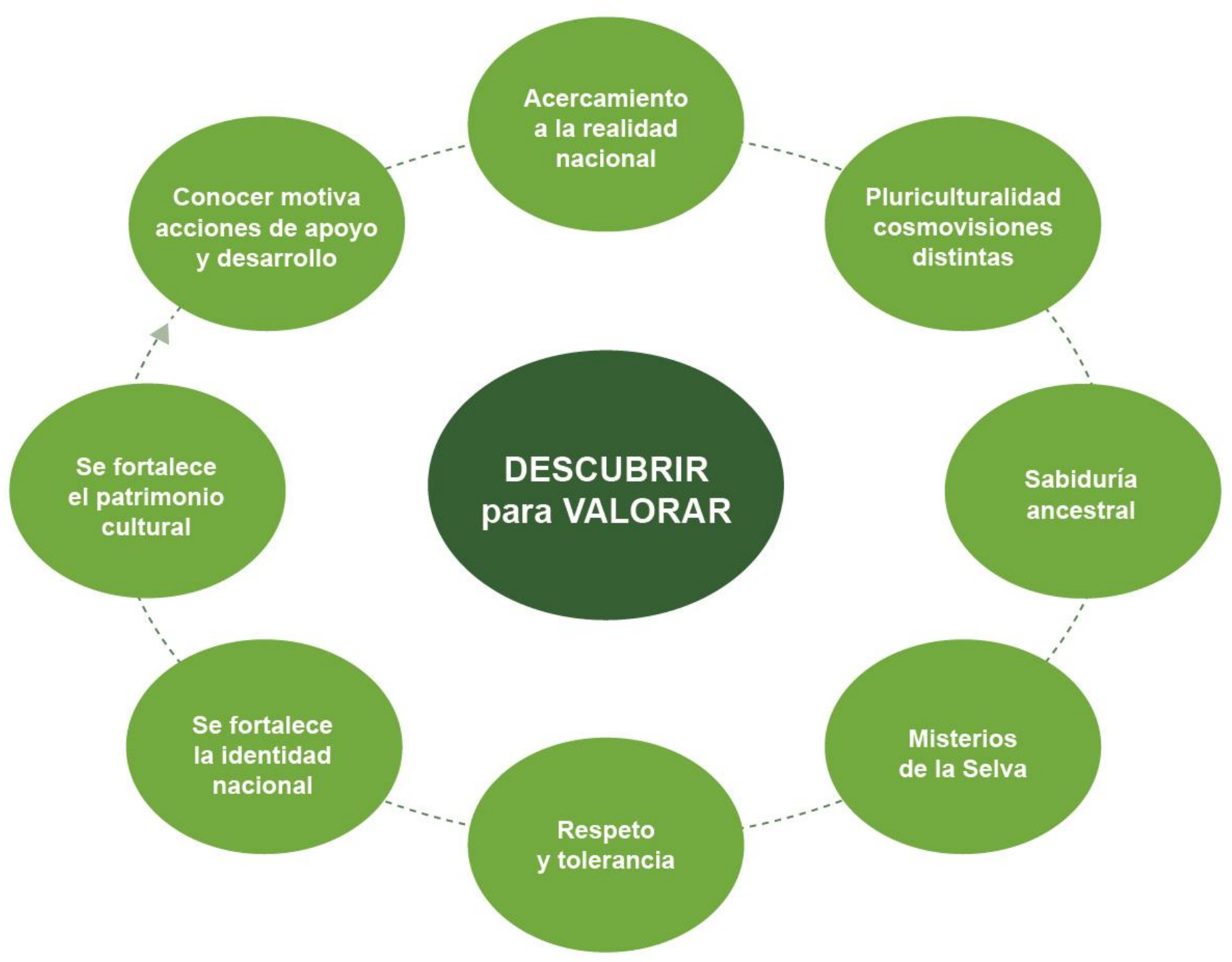

Figura 18. Concepto. Elaboración propia. 


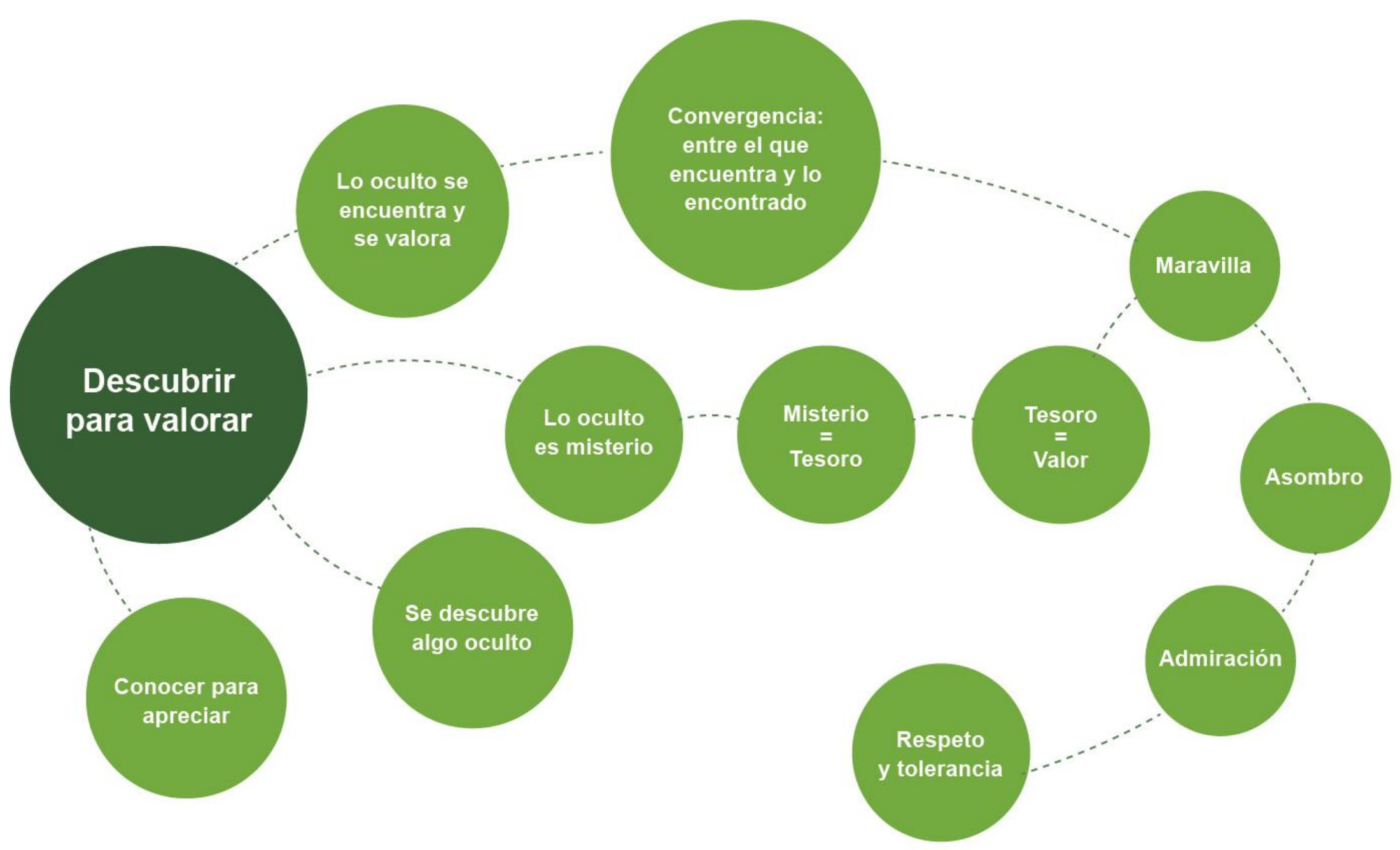

Figura 19. Palabras clave. Elaboración propia. 


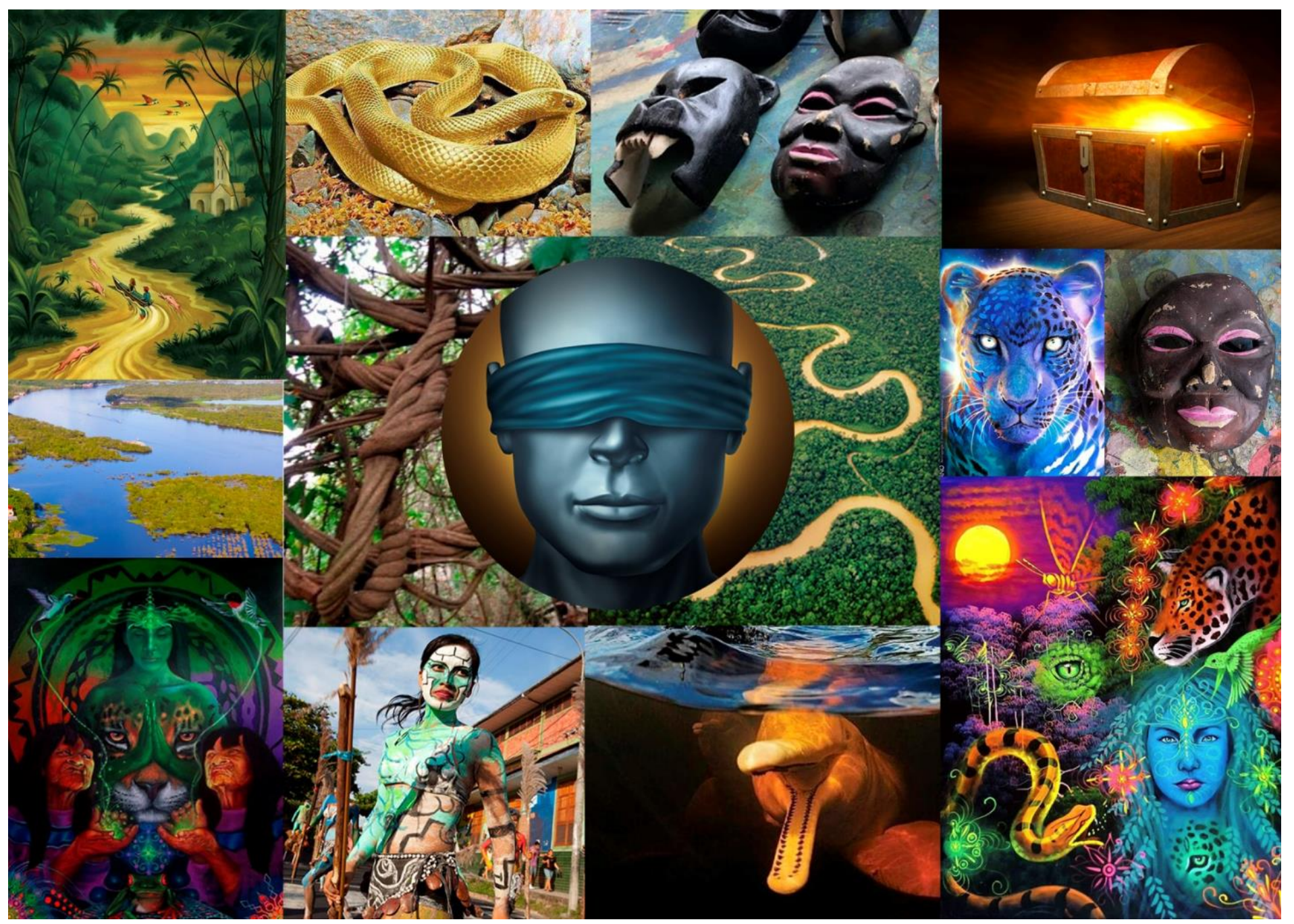

Figura 20. Moodboard. Elaboración propia. 
El proyecto responde a la investigación dadas las características del público objetivo, que prefiere más la imagen al texto, que muestra interés por lo nuevo y o desconocido y que se interesa por el desarrollo social. La idea no es mostrar a los pobladores de las etnias selváticas como seres desvalidos sino como personas que tienen culturas y cosmovisiones distintas que merecen ser respetadas en su diversidad. Además, el libro tendrá una presentación digital, dado el perfil del público objetivo, nativos digitales y ampliamente conectados.

\subsection{Diseño de la Comunicación}

\section{- $\quad$ Receptor (Público Objetivo)}

Los receptores son estudiantes de comunicación de primeros ciclos (tercero, cuarto y quinto ciclo) de la Universidad de Lima. Sus características han sido mencionadas en el punto 4.1. Análisis del público objetivo, y previamente en el marco teórico, punto f. Generación Z. Estas se resumen en las infografías (figuras 20 y 21), que muestran las características generales de esta generación en Lima, según un estudio de Ipsos Investigación de Mercados (2019), y las características específicas de los alumnos de la Facultad de Comunicación de la Universidad de Lima.

\section{- $\quad$ Emisor}

El Plan Maestro de la Universidad de Lima contempla la importancia de trabajar en el marco de la tolerancia y la diversidad; por ello se eligió a esta institución como emisora del proyecto.

Se plantea contar con voceros importantes tanto por la temática como por el público objetivo, como: Sonaly Tuesta Altamirano, conductora del programa "Costumbres", nacida en el departamento de Amazonas y con amplio conocimiento de 
las distintas cosmovisiones que del país; Pedro Horna, recientemente licenciado en Comunicación de la Universidad de Lima con el documental fotográfico Bekanwe, de corte antropológico visual, realizado con el objetivo de estudiar y desmitificar el modus vivendis de la Comunidad Nativa Shipibo Konibo Puerto Firmeza; Carlos Rivadeneyra Olcese, responsable de la especialidad de desarrollo de la Universidad de Lima; Caroline Cruz Valencia, Magister en Estudios Culturales y Pablo Taricuarima Paima, artista plástico y promotor de la cultura Kukama Kukamiria.

- Mensaje

"Descubrir para valorar".

\section{- $\quad$ Canales y medios}

Charla informativa: que tiene como objetivo concientizar al público objetivo sobre la pluriculturalidad en las cosmovisiones de la Selva Amazónica. La difusión de esta charla se realizará vía los canales de comunicación de la institución educativa donde se encuentra el público objetivo: comunicación de la actividad en vivo y en redes sociales.

Redes sociales: se creará una página de Facebook y una de Instagram para la difusión de la información. 


\section{Generación Z: Entre 13 y 20 años NATIVOS DIGITALES}

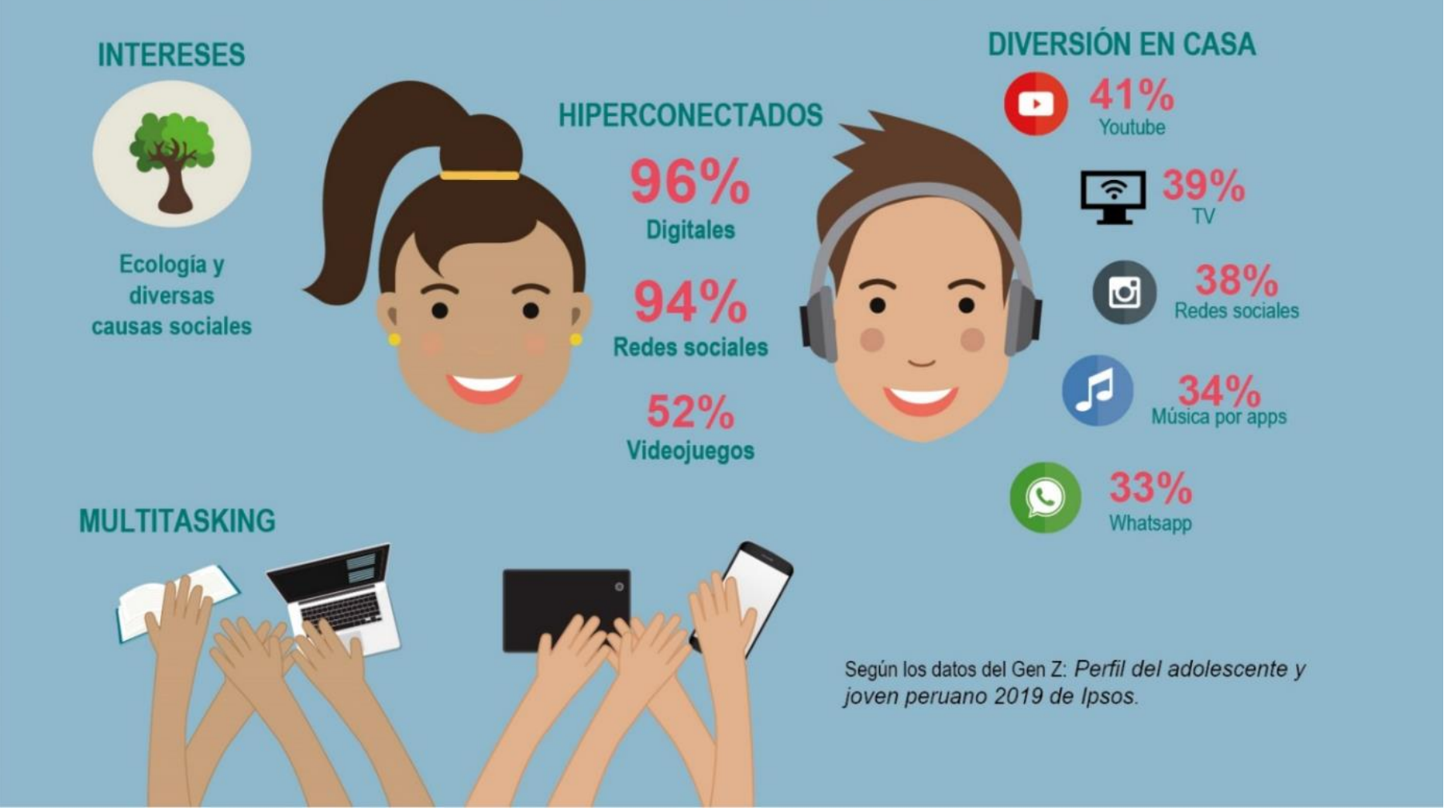

Figura 21. Características generales de la Generación Z. Incluye a todos los integrantes de esta generación, incluidos los más jóvenes (13 a 16 años), que no son parte del público objetivo. Lo datos fueron tomados de Gen Z: Perfil del adolescente y joven peruano 2019 de Ipsos, e incluye a todos los niveles socioeconómicos del Perú Urbano. 


\section{Generación Z: Público objetivo específico}

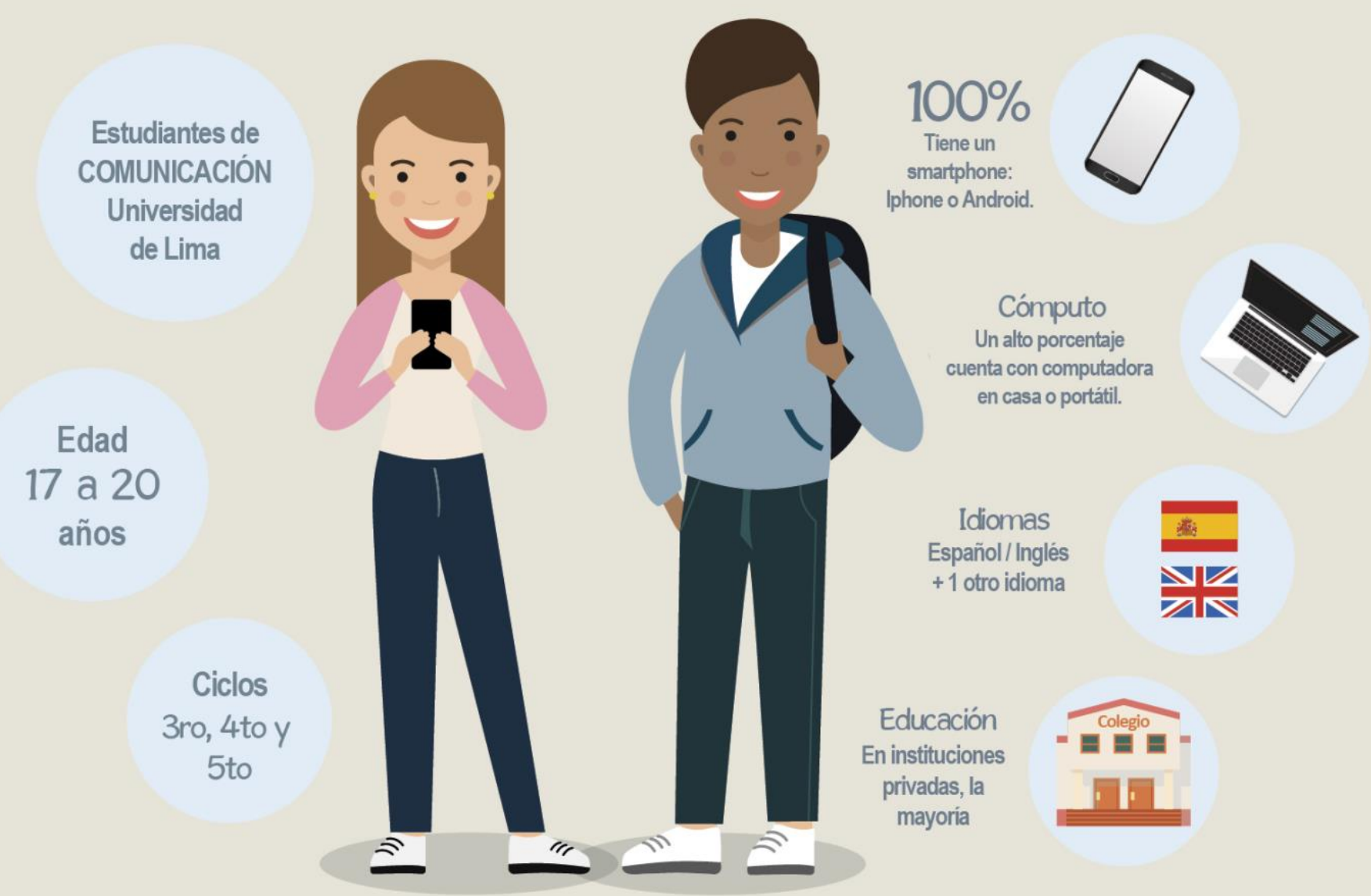

Figura 22. Características del público objetivo específico. Estudiantes universitarios de comunicación de la Universidad de Lima. 


\subsection{Estudio de la comunicación}

\section{- $\quad$ Estética}

La estética del libro da predominio a la imagen, con poco texto. Se busca comunicar, en lo posible, con la ilustración; en algunos casos, como en el primer fascículo, se hace uso de pocos globos, dada la naturaleza más libre de los contenidos visuales, que son en su mayoría las visiones y sueños de uno de los personajes.
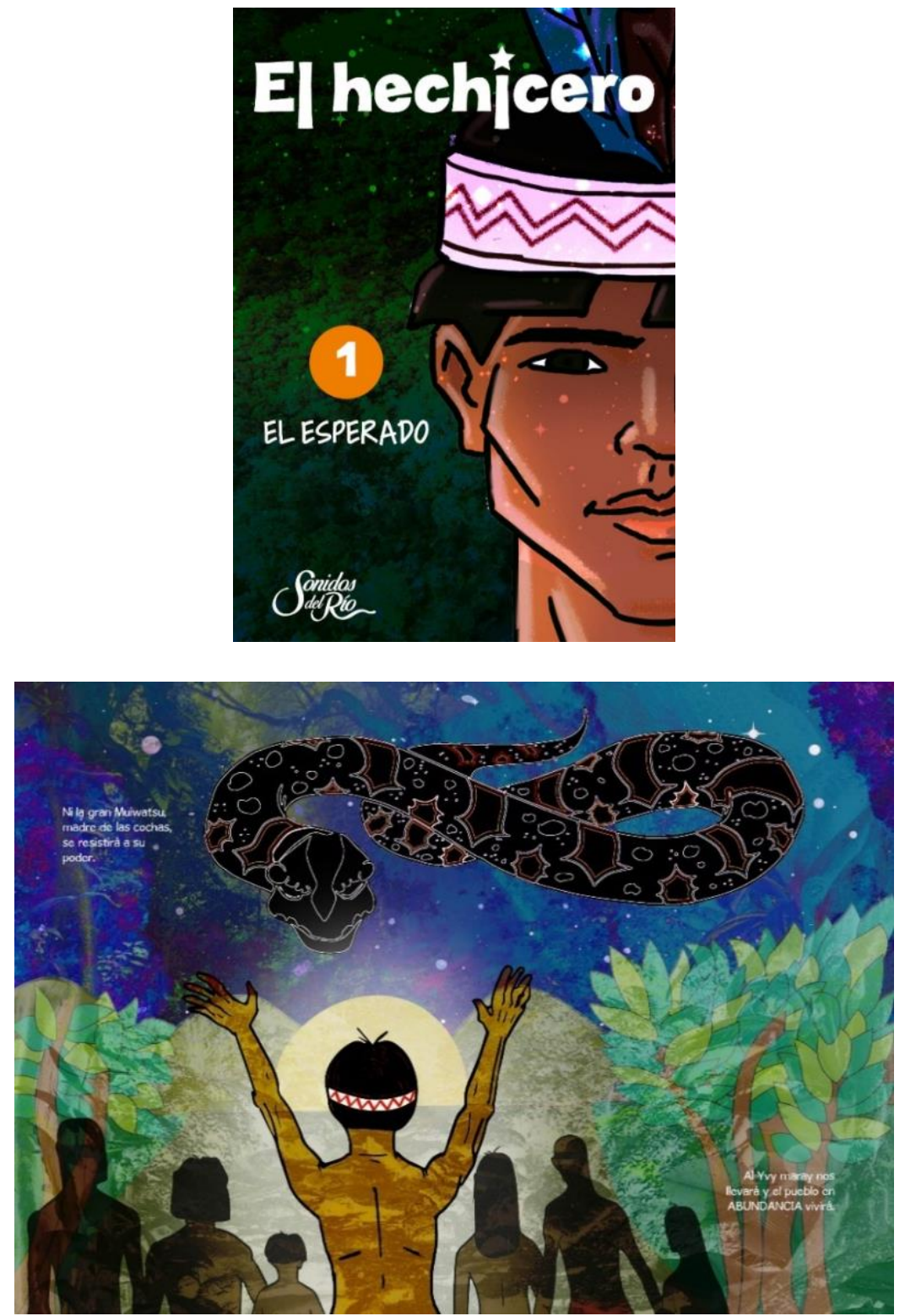

Figura 23. Portada y detalle de interiores de El hechicero. Elaboración propia. 
Logotipo de la marca: La estética del logotipo de la marca implicó el uso de una letra de tipo caligráfico, inspirada en los carteles del entorno urbano amazónico.

El movimiento del agua del logotipo se ve reflejado en el estilo curvilíneo y sinuoso de la tipografía y en las modificaciones a las formas de la $\mathrm{S}$ y la $\mathrm{R}$, creadas para resaltar ese objetivo. (Figura 24).

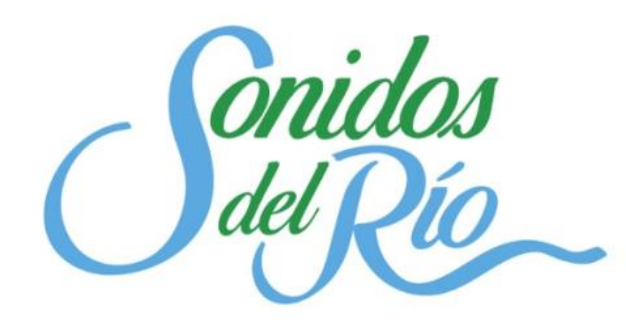

Figura 24. Logotipo "Sonidos del río". Elaboración propia.

Paleta de colores: En un principio los colores se eligieron tomando como punto de partida el moodboard visual presentado en la figura 19. Posteriormente, luego de que se obtuvieran más referencias fotográficas en el trabajo de campo, se realizaron algunos ajustes, aunque básicamente la paleta mantiene el cromatismo original obtenido, que refleja la abundancia de color de esta zona; se ha optado por una cromática saturada, de alto contraste, para reforzar la naturaleza exuberante, colorida y heterogénea de la zona. (Ver figura 24).

Tipografías: Para la elaboración del logotipo de la marca se partió de la tipografía Baird of Paradise, la cual fue modificada en la creación del logotipo estilo lettering. Para la obra se utilizaron tres tipografías, una para el logotipo (El hechicero) y las otras para el desarrollo del contenido. Las tipografías de la obra fueron seleccionadas por su relación visual con las letras utilizadas en narraciones visuales 
tipo cómic o novela gráfica; se priorizó para interiores la legibilidad y el correcto desempeño de las letras en textos de largo mediano. Ver figuras 25 y 26.
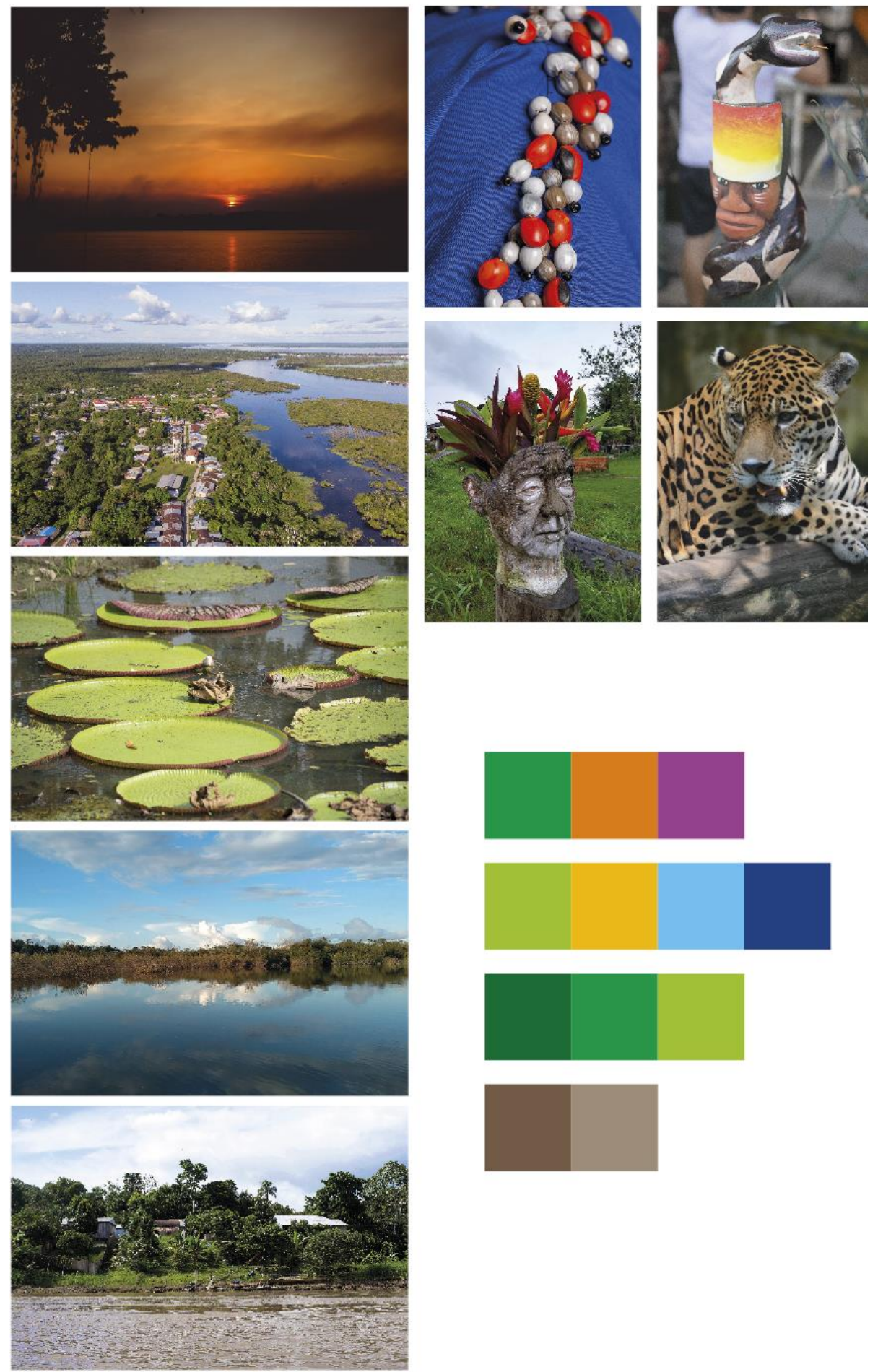

Figura 25. Paleta de colores final. Inspirada en la naturaleza y en las producciones de diferentes etnias. Fotos obtenidas durante la elaboración del proyecto. Foto de otorongo: Depositphotos. Fuente: Elaboración propia. 
Tipografía de Logotipo Sonidos del Río

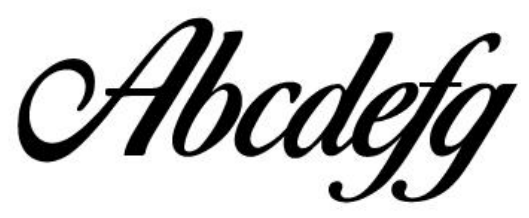

Birds of Paradise

\section{Logotipo \\ Abcdefg}

Cabold Comic

Interiores

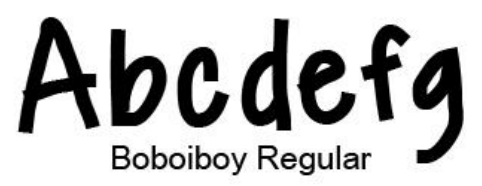

Abcdefg

GosmickSans

Figura 26. Tipografías para logotipo de "Sonidos del río" y El hechicero. Fuente: Elaboración propia.

\section{티 hech ${ }^{\ddagger}$ eero}

CABOLD COMIC

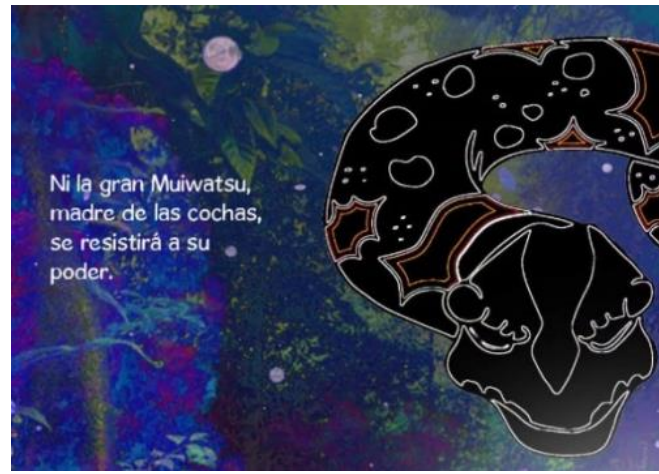

GOSMICKSANS

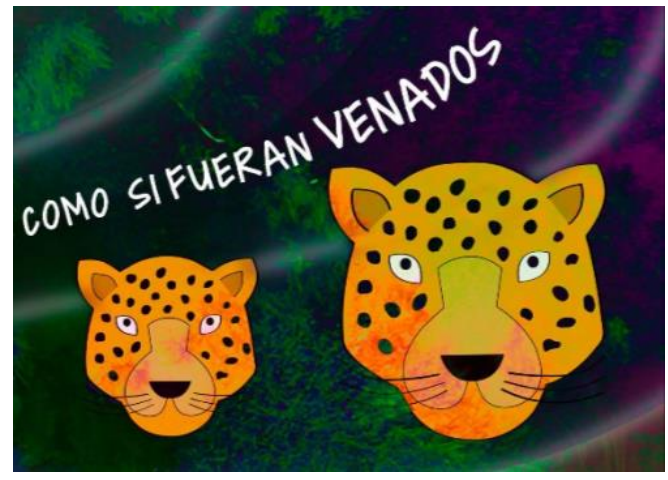

BOBOIBOY REGULAR

Figura 27. Tipografías de interiores aplicadas. Fuente: Elaboración propia. 


\section{Personajes principales:}

EL ESPERADO: El personaje principal de la novela es El Esperado, una especie de Mesías de la historia que llevará a su pueblo a la Tierra sin mal.

Características: joven, 18 años, atlético, cabello corto, mirada penetrante, labios grandes. Lleva una corona adornada con plumas de aves, una de ellas de gavilán, utilizadas en las coronas masculinas. Es enigmático, pero no triste.

El diseño que lleva en su corona y brazo derecho es de la iconografía Kukama de la comunidad de Santo Tomás y significa "Exaltación de la magnitud de las corrientes de ríos y las orillas" (Parana-pura). En su ropaje lleva el símbolo que significa "Protección" (Yatamani).

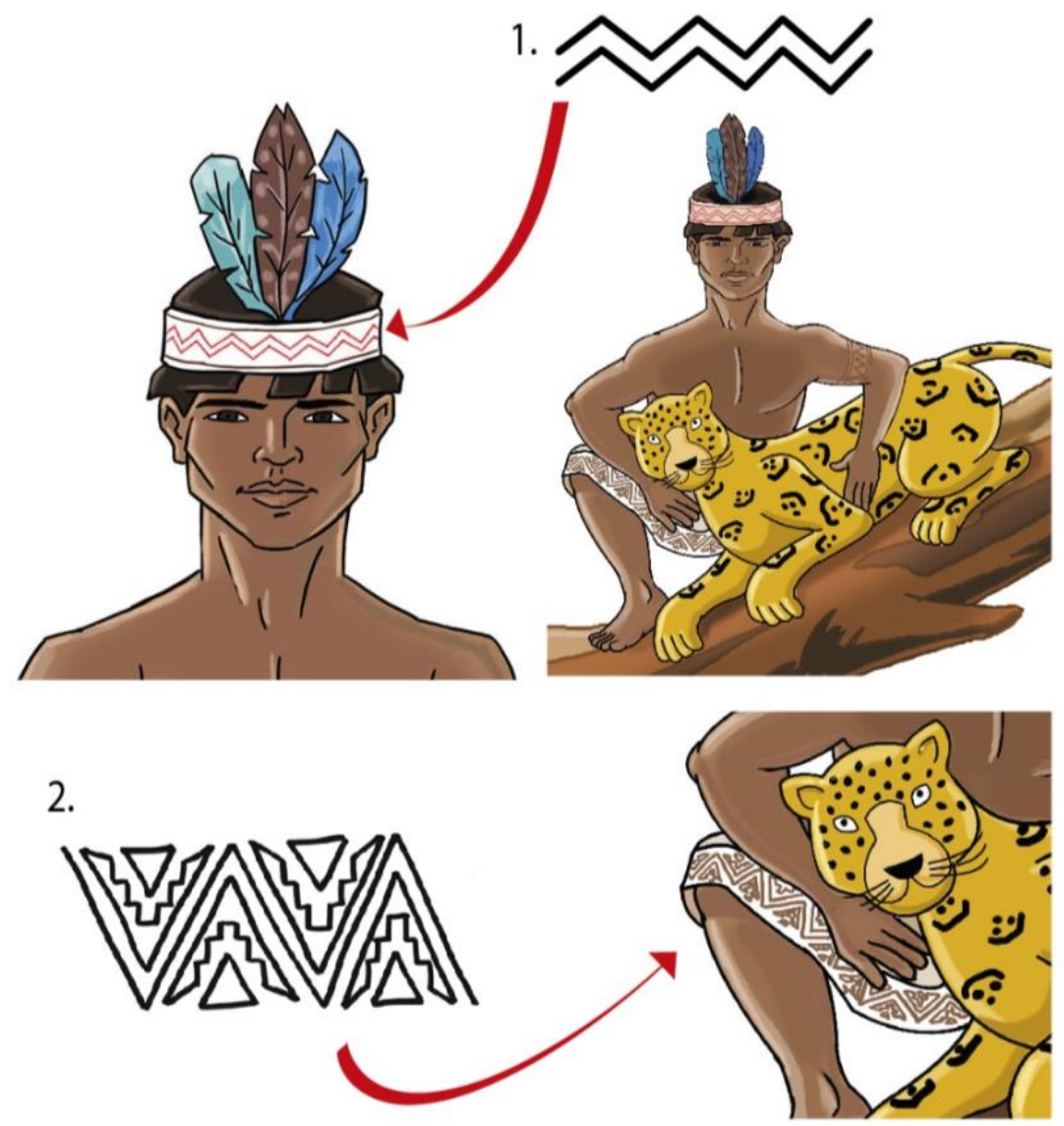

Figura 28. Caracterización de El Esperado. 1. "Exaltación de la magnitud de las corrientes de ríos y las orillas". 2. "Protección".

Fuente: Elaboración propia. Simbología: Asociación Cultural Yrapakatun. 
EL CHAMÁN: Persona mayor, 55 años, fuerte, cabello corto, ojos grandes hundidos, labios grandes. Lleva una corona de piel de anaconda adornada con plumas de gavilán y de guacamayo. Cabe señalar que se modificó la corona original, con huayruros, vista en las referencias, para despejar el rostro.

Lleva en su vestuario una iconografía Kukama Kukama de la comunidad de Santo Tomás que significa "Espíritu caminante de los sueños" (Uwata-wara).
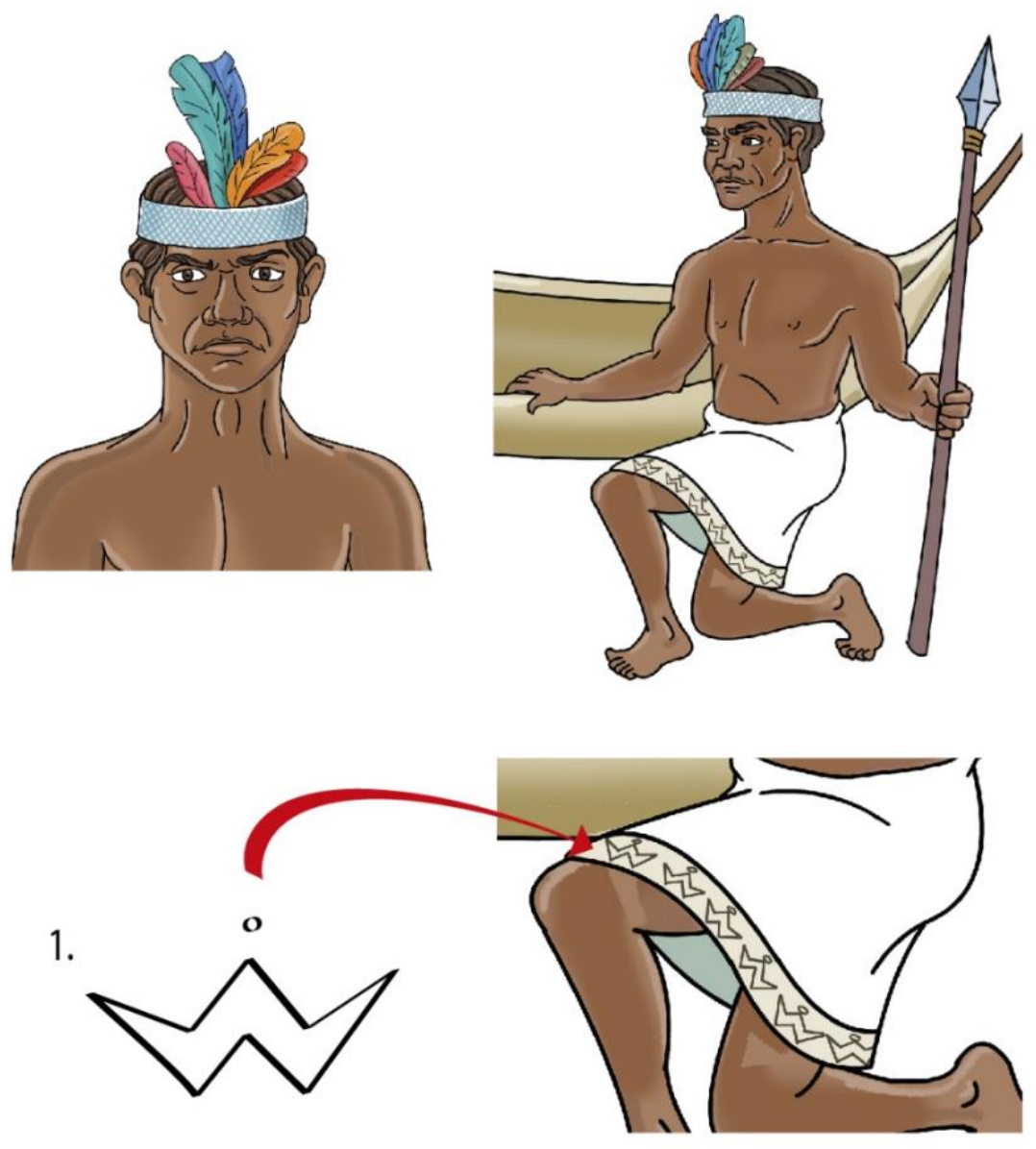

Figura 29. Caracterización de el Chamán. 1. "Espíritu caminante de los sueños". Fuente: Elaboración propia. Simbología: Asociación Cultural Yrapakatun. 


\section{- $\quad$ Pragmatismo}

Las piezas han sido pensadas en base a las actitudes de los adolescentes respecto a la lectura de textos; prefieren la imagen al texto, y por este motivo el libro original se adaptó un formato de novela gráfica. Además, con la imagen se evidencian características étnicas y de la cosmovisión, además de pasajes históricos que en el libro se describen detalladamente. Cabe señalar que la historia original, punto de partida del proyecto, cuenta con aproximadamente 100 páginas de solo texto en el capítulo 1 .

\section{- Simbología}

La paleta de colores, inspirada en la naturaleza y en las representaciones culturales de la zona, el uso de formas animales del bosque y acuáticos típicos y las iconografías específicas de los Kukama Kukamiria son elementos que generan una relación visual directa con la Selva y su cultura. Todos los elementos simbólicos de la obra fueron investigados y validada su pertenencia a la zona antes de su caracterización.

\section{- $\quad$ Sintaxis}

Al tratarse de una historia plena de matices que escapan a una lógica convencional se buscó reflejar esta esencia en la composición y en la distribución de elementos, con imágenes que contienen diversos referentes icónicos de la Amazonía presentados de una manera libre. En este primer número se ha dado mayor peso a la narrativa con muy pocas viñetas, de modo que la ilustración exprese, a través del color y las formas orgánicas propias de la zona, parte de la esencia del arte amazónico, que no separa la naturaleza de sus manifestaciones artísticas, y de su narrativa, mayormente oral, y donde no siempre existe un inicio, nudo y desenlace. 
Cabe señalar, que no se han considerado en este primer fascículo muchos componentes de la narrativa gráfica convencional (viñetas, cartelas y bocaditos) precisamente para comenzar la historia con una atmósfera etérea, mágica y con pocas restricciones pues es la presentación de El Esperado a través de las visiones y sueños de El Chamán. Cabe señalar que dichos recursos sí se han considerado en los siguientes fascículos que cuentan con momentos más realistas y de interacción de personajes, como en el fascículo 2, El aviso de la ayahuasca, que narra las visitas de representantes de otras etnias a "El Esperado" y las conversaciones de los distintos chamanes de las etnias o posteriormente Paraíso en peligro y Epidemia que cuentan la inminente llegada de los españoles y los estragos generados. Para preservar la unidad gráfica en los números posteriores, la atmósfera del primer fascículo se mantendrá en el manejo del color y en la presentación de visiones, sueños, mitos y personajes propios de la Amazonía con la dinámica planteada en el primer fascículo.

\subsection{Juicio de pares}

Debido a la coyuntura Covid 19, la validación del proyecto se realizó por el sistema de “Juicio de Pares", cuyos informes se presentan en la sección: Anexos (1).

$\mathrm{Al}$ respecto se consideró conveniente contar con una gama diversas de especialistas, tanto en el campo del diseño gráfico como en el de la comunicación social.

Se contó con la apreciación de siete pares: César Carrión Osores, Sandra Tineo Sanguinetti, Claudia Torres Duncker y Alfredo Oshiro Fukuhara en el campo del diseño gráfico; Jenny Canales Peña y Caroline Cruz Valencia, en el campo de la comunicación social; y Álvaro Feliu, especialista en arte secuencial.

Los comentarios fueron positivos respecto a la temática elegida y a su relevancia en relación a la necesidad de visibilizar la Selva amazónica. Asimismo, fue bien considerado el 
tratamiento del color de las ilustraciones. Se han tomado en cuenta algunas recomendaciones y realizado los respectivos ajustes, otras se realizarán luego de la presentación de prueba ante el público objetivo.

Entre las sugerencias se encuentra hacer un mayor uso de los recursos tradicionales de la narrativa gráfica, como viñetas, bocaditos, cartelas, etc., lo cual fue sustentado en el punto precedente.

A este respecto, cabe señalar que se busca una narrativa gráfica acorde al perfil del público objetivo sin dejar de lado el estilo propio de las narraciones orales amazónicas, con una lógica no convencional; por eso la narración es más libre y sin restricciones, en concordancia con lo señalado por Feliu y Cruz.

Precisamente uno de los aspectos en los que coinciden dos de los profesionales que han realizado la evaluación de pares, es en la importancia de conocer el punto de vista del público objetivo. Este tema, considerado de suma trascendencia para la continuación del proyecto y la realización de los ajustes necesarios, no se llegó a implementar, como ya se mencionó, debido a la Pandemia Covid 19. No obstante, se han recibido comentarios positivos de parte de algunos jóvenes estudiantes de la Universidad de Lima, además, se ha considerado la realización de un focus group y la implementación inicialmente programada a corto o mediano plazo.

Si bien no fue posible llevar a cabo la implementación en el campus de la Universidad de Lima, se explica brevemente la estrategia planteada para el lanzamiento.

El proyecto contempla una activación en línea para iniciar a una campaña de intriga en Instagram, con rebote en Facebook, sobre las realidades amazónicas, que culminan con el lanzamiento del libro. Algunos posts se trabajan bajo la estrategia de espejo en Facebook para llegar también a un público objetivo secundario de mayor edad que utiliza este medio de 
comunicación como red principal, y a posibles usuarios finales como organizaciones que trabajan en la difusión de proyectos socioculturales en la Selva y que pueden posteriormente convertirse en aliados estratégicos.

Precisamente por este público secundario se realizarán publicaciones especiales solo para Facebook, que permite ahondar en el tema textual, para ampliar la información necesaria sobre cosmovisiones amazónicas y la temática del primer cuento.

También se consideró realizar una charla sobre culturas amazónicas y la presentación de la novela gráfica en las instalaciones de la Universidad de Lima. El panel estaría compuesto por los miembros citados en el punto “Emisor”, páginas 83 y 84 del presente documento.

Los resultados del impacto de este proyecto se medirán a través de una encuesta tomada a la salida de la charla y, con el registro de los likes y visitas tanto del Fan Page como de la página de Instagram. 


\section{Conclusiones}

- Las cosmovisiones y estilos de vida de la Amazonía son muy variados y es preciso difundirlos para ampliar el acervo cultural de los estudiantes universitarios, lo cual redundará en un futuro en una sociedad más justa y consciente, con respeto, tolerancia, empatía y solidaridad hacia las diferencias culturales.

- El Hechicero, primera producción de "Sonidos del río" es un producto que aporta en ampliar la comprensión del pluralismo étnico cultural de la Amazonía Peruana.

- Así como los Kukama Kukamiria, todas las comunidades son merecedoras de ser visibilizadas. Esta es una de las etnias menos conocidas o nombradas por el público objetivo, no obstante ser una de las más grandes de la Amazonía y con un bagaje cultural muy rico.

- La presentación de historias en formato de novela gráfica se ha vuelto de interés común en estos tiempos, dado el predominio de la preferencia cada vez más creciente por la imagen, que caracteriza a las nuevas generaciones. 


\section{Recomendaciones}

- A nivel de la academia se recomienda una mayor investigación en torno a la narrativa y al arte secuencial, así como de sus posibilidades educativas. Si bien la información es extensa a nivel internacional, hay poca investigación aún del campo peruano, que presenta importantes diferencias en el modo de narrar, tanto oral como a través de imágenes. Las narraciones orales de la Selva, por ejemplo, no concluyen en un desenlace comprensible para la lógica occidental.

- A nivel de investigadores que deseen realizar una novela gráfica ambientada en una zona poco conocida, se recomienda, en lo posible, tomar contacto con los pobladores y observar las costumbres; de preferencia en distintas zonas. En el caso de la Selva, el territorio es extenso y las comunidades de una misma etnia habitan en diferentes lugares; esto puede generar matices y variaciones que enriquecerán el producto.

- Adaptabilidad: si bien el presente proyecto no se llegó a implementar por la coyuntura, si se contó con las apreciaciones de jóvenes estudiantes, pues es importante en todo proyecto considerar al público objetivo. No obstante, la propuesta presenta riesgos en cuanto a que el estilo planteado escapa de los parámetros de la narrativa gráfica convencional, una decisión que fue tomada para no perder la esencia de la mística amazónica, y es posible se deban realizar los ajustes necesarios (tratando de lograr una confluencia entre público y el carácter de lo narrado) a medida que se vayan publicando los números y midiendo el interés que genera. 


\section{Referencias bibliográficas}

Asociación Cultural Yrapakatun. (2014). MURUTAKATARAPAN. Origen de los diseños Kukama Kukamiria. Loreto, Comunidad de Santo Tomás.

AIDESEP, Fundación Telefónica y Programa de Formación de Maestros Bilingües. (2000). El ojo verde: cosmovisiones amazónicas.

Agüero, Óscar. (1994). El milenio en la Amazonía peruana. Mito-utopía tupí-cocama o la subversión del orden simbólico. Lima: CAAAP. Quito: Ediciones ABYA-YALA.

Arango, J., Gómez, L. y Gómez M. (enero - junio de 2009). El cómic es cosa seria. El cómic como mediación para la enseñanza en la educación superior. Caso Universidad Nacional de Medellín y Universidad Pontificia Bolivariana. Anagramas, Volumen 7, N. ${ }^{\circ} 14$. pp. 13-32.

Base de Datos de Pueblos Indígenas u Originarios (BDPI). Pueblo Kukama Kukamiria. Ficha. Recuperado de: https://bdpi.cultura.gob.pe/pueblos/kukama-kukamiria

Bernabé V. M. (2012). Pluriculturalidad, multiculturalidad e interculturalidad, conocimientos necesarios para la labor docente. Revista Educativa Hekadermos. 11, Año V, junio 2012(67-76) (ISSN 1989-3558) Universidad de Valencia.

Blázquez M., J. (2005). Las res gestae de Trajano militar. Las guerras dácicas. Aquila legionis. Cuadernos de estudios sobre el ejército romano. $\mathrm{N}^{\circ}$ 6. pp. 19-55.

Chinn y Mc Loughlin. (2009). Curso de novela gráfica. Guion, personajes, color, maqueta, tipografía, bocadillos. Barcelona: Gustavo Gili, SL.

DW Documental. (4 de junio de 2019). Recorriendo el Amazonas peruano. Recuperado de: https://www.youtube. $\mathrm{com} /$ watch? $\mathrm{v}=\mathrm{tDd} 6 \mathrm{CIype} 1 \mathrm{I} \&$ feature=youtu.be $\& \mathrm{fbclid}=\mathrm{IwAR} 0 \mathrm{Nm}$ y4MNRagmzATqbBK_wGrYvLSyqaM-_pREN37mnPoNQ61NEDVt6y_GoA

Eisner, W. (1996). El comic y el arte secuencial. Recuperado de: https://dibujourjc.files.wordpress.com/2018/03/arte-secuencial-will-eisner.pdf

Gamero, Alejandro. (2008). Contrato con Dios, de Will Eisner. Recuperado de: https://lapiedradesisifo.com/2018/06/01/contrato-con-dios-de-will-eisner/

García, E. y otros. (2010) El cómic como recurso didáctico para el aprendizaje de las actividades físicas en el medio natural en el $2^{\circ}$ ciclo de la educación primaria española. REXE. Revista de Estudios y Experiencias en Educación, vol. 9, núm. 17, 2010 (117133), Universidad Católica de la Santísima Concepción, Concepción, Chile. 
Gonzales Mendiburu, Rosa. Las iluminaciones medievales, un ejemplo de narrativa gráfica. Pontificia Universidad Católica del Perú. Recuperado de:

http://revistas.pucp.edu.pe/index.php/memoriagrafica/article/view/20060/20067

Guía del Cómic. 300 de Frank Miller. Recuperado de:

http://www.guiadelcomic.com/frankmiller/300.htm

Hernán Mejía, M. (2013). El patrimonio cultural: Su gestión y su significado. Euroamericano VIII Campus. Recuperado de:

https://campuseuroamericano.org/pdf/es/ES_PATRIMONIO_CULTURAL_GESTION_ SIGNIFICADO_Mario_Mejia.pdf

Hernández, Max. (2000). ¿Es otro el rostro del Perú? Identidad, diversidad y cambio. Lima: Agenda Perú.

Hernández Sampieri, R., Fernández-Collado, C. y Baptista, P. (2006). Metodología de la Investigación. México: Mc Graw Hill.

Informe sobre desarrollo humano 2004. La libertad cultural en el mundo diverso de hoy. (2004). Programa de las Naciones Unidas para el Desarrollo (PNUD). Barcelona: Ediciones Mundi-Prensa.

Indicadores UNESCO de cultura para el desarrollo. Resumen analítico del Perú. (2013).

Organización de las Naciones Unidas para la Educación, la Ciencia y la Cultura (UNESCO) y Ministerio de Cultura Perú.

La Vanguardia. (2019). La generación Z tiene ganas de ver el mundo. Una encuesta realizada por Booking.com analiza las preferencias de estos jóvenes. Recuperado de: https://www.lavanguardia.com/ocio/viajes/20190719/463578931625/generacion-zviajeros-explorar-mundo.html

Levi Strauss, C. (1987). Mito y significado. Madrid: Alianza Editorial.

Marzal, M. (1981). La población nativa y las fronteras peruanas. Revista de la Universidad Católica/nueva serie/9-10, pp. 231-253.

Méndez Graf, I. (agosto de 2010). Los manuscritos iluminados. Algarabia, p. 110+. Gale OneFile: Informe Académico. Recuperado de: https://link-galecom.ezproxy.ulima.edu.pe/apps/doc/A382657321/IFME?u=ulima\&sid=IFME\&xid=9e3 444ee. Accessed 11 Feb. 2020.

Michaud, Cécile. (2015). Escritura e imagen en Hispanoamérica: De la crónica ilustrada al cómic. Lima: Fondo Editorial Pontificia Universidad Católica del Perú.

Ministerio del Ambiente - Servicio Nacional de Áreas Naturales Protegidas y otros. (2009). Plan Maestro Reserva Nacional Pacaya Samiria 2009-2013. Lima: sin editorial. 
Morales, B. (15 de abril de 2016). Ciudad de payasos: las mutaciones de un texto. Recuperado de: https://www.senalc.com/2016/04/15/ciudad-de-payasos-las-mutacionesde-un-texto/

Morel, J. (2010). De una a muchas Amazonías. Los discursos sobre 'La Selva' (1963-2012). En: Amazonía peruana y desarrollo económico. Editores: Barrantes R. y Glave, M. Lima: Instituto de Estudios Peruanos (IEP) y Grupo de Análisis para el Desarrollo (GRADE).

Núñez Alayo, E. (2010). Novela gráfica peruana (tesis para optar el grado académico de Magíster en Comunicaciones). Pontificia Universidad Católica del Perú (PUCP).

Ochoa, J. (2002) Mito y Chamanismo: El mito de la Tierra sin mal en los tupí-cocama de la Amazonía peruana. Tesis para optar el título de Doctor en Filosofía. Universidad de Barcelona.

Papel en blanco. (2009). 'Arrugas 'de Paco Rocas. Recuperado de: https://papelenblanco.com/arrugas-de-paco-roca-3837c24b41a

Peralta, Germán. (15 de junio de 2019. Conversatorio con Germán Peralta, dibujante argentino de Marvel Comics. Universidad de Lima.

Piazzini, Franco. (2000). Análisis de la situación social en la Amazonía. En: Revista de Marina. Callao: Marina de Guerra del Perú.

Planeta Cómic. (2019). Selva misteriosa. Recopilación de historietas de Juan Flórez del Águila. Lima: Planeta Cómic.

Prensky, M. (SF). Nativos e inmigrantes digitales. Institución Educativa SEK.

ProyContra. (1 de marzo de 2019). Derechos territoriales de kukamas. Recuperado de: https://proycontra.com.pe/derechos-territoriales-de-kukamas/

Quispe Díaz, Jorge Manuel. (2018). El reforzamiento de la etnicidad shipibo-konibo de las niñas y los niños de la comunidad Bena Jema por influencia de la educación intercultural bilingüe (tesis para optar el título de Licenciado en Antropología). Pontificia Universidad Católica del Perú (PUCP).

Ramírez Colombier, M. (2018). Cuerpos y territorialidad del pueblo Kukama en la política contemporánea sobre la Amazonía, elaborada por Marco Arturo Ramírez Colombier (tesis para optar el grado de Magister en Antropología). Pontificia Universidad Católica del Perú (PUCP).

Rivas, R. (2004). El gran pescador. Técnicas de pesca entre los cocamas-cocamillas de la Amazonía Peruana. Lima: Fondo Editorial Pontificia Universidad Católica del Perú. 
Rocas, Paco. (2011). Paco Rocas, un truhan, un señor. Recuperado de: http://www.pacoroca.com/portfolio/arrugas

Rodríguez, Silverio. (2017). La Riskina, Secretos escondidos de la Amazonía peruana. En: Boletín de Lima, Vol. XXXIX, N. 187, Año 39.

San Román, J. (1994). Perfiles históricos de la Amazonía Peruana. Iquitos: Centro de Estudios Teológicos de la Amazonía (CETA).

Tawa. (2018). Ayar. La leyenda de los Inkas. Lima: Planeta Cómic.

Trabado, J. (2012). Antes de la novela gráfica. Clásicos del cómic en la prensa latinoamericana. Madrid: Cátedra, Signo e imagen.

Vail, G. (2019). Reconstruyendo rituales de la élite maya en las tierras bajas del norte. una mirada desde los códices mayas y ek' balam. Revista Española De Antropología Americana, 49, 241-263. doi: http://dx.doi.org.ezproxy.ulima.edu.pe/10.5209/reaa.64969

Warletta, V. (2017) Reseña de 'Ich: Naturaleza salvaje', de Ariel Olivetti y Luciano Saracino. Recuperado de: https://www.lacasadeel.net/2017/01/resena-ich-naturalezasalvaje-ariel-olivetti-luciano-saracino.html

Wigan, Mark. (2008). Imágenes en secuencia. Animación, storyboards, videojuegos, títulos de crédito, cinematografía, mash-ups. Barcelona: Gustavo Gili, SL.

Zafra, Remedios. (2010). Un cuarto propio conectado.

\section{Web sites adicionales:}

http://www.caaap.org.pe/website/

http://repositorio.ana.gob.pe/ 
ANEXOS 
ANEXO 1: JUICIO DE PARES 


\section{Juicio de pares}

Lima 9 de julio de 2020

Señores,

Escuela de Posgrado

Universidad San Ignacio de Loyola

Por medio de la presente me dirijo a ustedes a fin de poder dar una opinión objetiva respecto al proyecto de diseño para la tesis titulado "Aplicación de la novela gráfica inspirada en la comunidad Kukama Kukamiria para enriquecer el acervo multicultural de estudiantes de comunicación" diseñado por la Bachiller Rocío Emilia Villacorta Calderón, referido a un problema muy complejo y grave, que es el desconocimiento de un sector mayoritario de la población peruana sobre la riqueza y diversidad cultural del mundo amazónico. El proyecto busca acortar esa distancia y afianzar la comprensión mutua.

Ya que la cultura impacta y modifica la calidad de vida, considero acertada la elección de la historieta digital como herramienta y vehículo actualizado para impactar en ella. Considero también muy positiva la elección de estudiantes de comunicación como público objetivo, ya que el proyecto busca un efecto multiplicador del mensaje. En ese sentido, consideraría importante un sondeo y validación constante durante el proceso de diseño, para asegurar la sintonía con el público en cuanto a comprensión y expectativa estética, ya que no debemos olvidar que el proyecto no obedece exclusivamente a las necesidades de expresión del artista gráfico sino a objetivos puntuales. Sería importante también validar un punto enunciado en las consideraciones del proyecto: evitar la exotización de la población por las diferencias culturales. Ya que estos aspectos suelen convertirse en un atractivo normal de este tipo de productos, es importante que dichas diferencias sean bien entendidas como enriquecedoras de nuestra identidad como país.

Quisiera resaltar el uso del color en este proyecto, que logra plasmar muy bien el espíritu de la Amazonía y por lo tanto va en consonancia con el tema. Me atrevería a recomendar, sin embargo, una integración mayor de todos los colores en cada página, que podría lograrse con la influencia de una tonalidad dominante o una textura integradora, como la que se logra en alguna de las páginas del fascículo de muestra.

Por lo tanto, al analizar y revisar el proyecto minuciosamente encuentro que es importante y pertinente, ya que su objetivo es la atención de un problema crucial en nuestro país. Considero además que la herramienta elegida para la realización del proyecto, la narrativa gráfica, no es solo un canal comunicativo más, sino que, por sus características estéticas, se convierte en un mensaje en sí mismo, ya que materializa visualmente los elementos de la cultura y cosmovisión amazónicas. Por lo tanto, su 
realización requiere no solo capacidad artística sino un gran esfuerzo de investigación y ejecución.

Atentamente

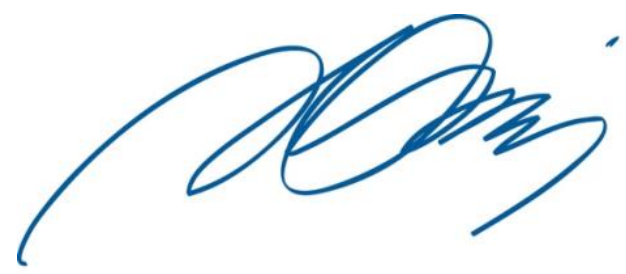

Mg. Alfredo Oshiro Fukuhara 


\section{Juicio de pares}

Lima 9 de julio de 2020

Señores,

Escuela de Posgrado

Universidad San Ignacio de Loyola

Por medio de la presente me dirijo a ustedes a fin de poder dar una opinión objetiva respecto al proyecto de diseño para la tesis titulado "Aplicación de la novela gráfica inspirada en la comunidad Kukama Kukamiria para enriquecer el acervo multicultural de estudiantes de comunicación". diseñado por el Bachiller Rocío Emilia Villacorta Calderón referido a que existe un problema muy complejo y grave, que es el desconocimiento de la realidad(es) de la selva amazónica en referencia a la parte cultural de la población, que se ve disminuida sin esa riqueza y saber milenario que la caracteriza, que es distinta, pero igualmente valiosa y desarrollada en concordancia con su estilo de vida y hábitat.

Por lo tanto, al analizar y revisar el proyecto minuciosamente encuentro que el mismo es importante, pertinente para el logro del conocimiento, reconocimiento y autoaceptación de la cultura amazónica no sólo a nivel externo, es decir, a público ajeno al conocimiento de la riqueza cultural de la Amazonía, sino también a nivel interno, ya que durante años las poblaciones que habitan la selva amazónica han sufrido, durante el proceso de mestizaje, diversos maltratos en relación a su identidad, teniendo, según lo revisado, una carencia o disminución de orgullo por sus orígenes, tradiciones, etc. La difusión de la cultura amazónica en la aplicación de la presente propuesta de diseño me parece adecuada debido a que incentiva al lector a una inmersión cultural por medio de la narrativa y de la ilustración en medio de un contexto actualizado y amigable que puede llegar incluso más allá del público objetivo trazado para despertar conciencia y beneficiar o tratar de contribuir a la búsqueda de las soluciones planteadas.

\section{Atentamente}

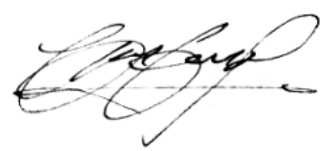

Mg. Claudia Viviana Torres Duncker 


\section{Juicio de pares}

Lima 9 de julio de 2020

Señores,

Escuela de Posgrado

Universidad San Ignacio de Loyola

Por medio de la presente me dirijo a ustedes a fin de poder dar una opinión objetiva respecto al proyecto de diseño para la tesis titulado "Aplicación de la novela gráfica inspirada en la comunidad Kukama Kukamiria para enriquecer el acervo multicultural de estudiantes de comunicación" diseñado por el Bachiller Rocío Emilia Villacorta Calderón referido a que existe un problema muy complejo y grave que es el desconocimiento de la realidad(es) de la Selva amazónica.

Por lo tanto, al analizar y revisar el proyecto minuciosamente encuentro que el mismo es importante, en la manera en que establece un canal de comunicación, "puente" entre la sociedad(es) amazónicas y el resto de la población del Perú, el transmitir esta información, a través de historias folklóricas, utilizando la narrativa visual, no solo emula la idiosincrasia de estas comunidades, utilizando la misma manera en la que ellos narran las historias de generación en generación, manteniendo las tradiciones vivas hasta la actualidad, he ahí una primera manera de generar un nexo comunicativo entre ambas realidades.

Acerca de la narrativa visual, llamada propiamente arte secuencial, es una técnica para contar historias de toda índole y contexto, en algunos países en donde se encuentra más difundida, se utiliza en material de tipo informativo e inclusive educativo, ya que la combinación de la narrativa con imágenes la convierten en una poderosa arma comunicativa, de fácil entendimiento para un amplio espectro de públicos y capaz de transmitir mucha información a la vez, debido a la utilización de varios códigos y símbolos visuales al mismo tiempo.

Lamentablemente, en los últimos años, este arte se ha visto relegado a la industria del entretenimiento, debido a que uno de sus más grandes exponentes, la historieta (comic) ha adquirido una relevancia importante en combinación con la industria cinematográfica y televisiva.

En países como el nuestro, donde el arte secuencial no ha tenido una difusión y utilización masiva, sino más bien de manera subterránea, y en donde se ha dado a conocer en mayor escala en la última década, pues queda encasillado bajo el estereotipo mencionado líneas arriba, de un documento de mero entretenimiento, carente de mayor calidad substancial, despojándole de su capacidad informativa, es por eso que, poner este arte al servicio de una empresa como esta, para dar a conocer la riqueza, alcance y complejidad de la idiosincrasia amazónica, no solo como una atracción turística, sino como un mundo vibrante, de alguna manera reivindica también el valor informativo y literario del arte secuencial.

Por esta razón me parece que la elección de llevar este proyecto a un cuento ilustrado o novela gráfica es una propuesta totalmente adecuada.

En el ámbito gráfico, los códigos visuales utilizados, combinando imágenes fotográficas retocadas e ilustraciones, sumadas a una paleta de colores brillantes y saturados, abarrotados de patrones, componen imágenes visuales poderosas, transmisoras a modo de cuento, la viñeta es dejada de lado para dar paso a la 
ilustración, haciendo que la narrativa adquiera un carácter libre, sin restricciones, le aportan el componente psicodélico encontrado quizás, en un viaje astral inducido.

Atentamente

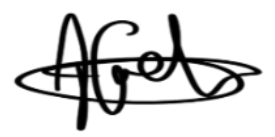

Alvaro Feliu Gutiérrez

Mg. Arte 


\section{Juicio de pares}

Lima 9 de julio de 2020

Señores:

Escuela de Posgrado

Universidad San Ignacio de Loyola

Por medio de la presente me dirijo a ustedes a fin de poder dar una opinión objetiva respecto al proyecto de diseño para la tesis titulado Aplicación de la novela gráfica inspirada en la comunidad Kukama Kukamiria para enriquecer el acervo multicultural de estudiantes de comunicación, diseñado por el Bachiller Rocío Emilia Villacorta Calderón referido a que existe un problema muy complejo y grave que es el poco conocimiento de la Amazonía.

Por lo tanto, al analizar y revisar el proyecto minuciosamente encuentro que el mismo es importante y pertinente por la visibilización a una región del país que tiene poca presencia en la agenda política, educativa, salud, cultural y económica. Desde el diseño de este fascículo se define la sensorialidad amazónica con los trazos y colores, los escenarios y figuras humanas y de animales propios de la región. En un segundo nivel, la historia y personajes narran en una lógica no occidental (inicio, nudo y desenlace), sino desde el final abierto para la continuación del relato. Finalmente, se proponen valores como el cuidado de la naturaleza, en la historia la naturaleza no es hostil y permite la convivencia de todas las criaturas, es un milagro de la vida.

Esta historia busca despertar conciencia y beneficiar a los jóvenes estudiantes con historias nuevas y refrescantes que son parte de la historia de todos los peruanos.

Atentamente,

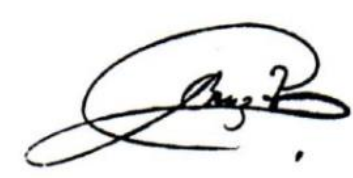

Mg. Ana Caroline Cruz Valencia 


\section{Juicio de pares}

Lima 6 de agosto de 2020

Señores,

Escuela de Posgrado

Universidad San Ignacio de Loyola

Por medio de la presente me dirijo a ustedes a fin de poder dar una opinión objetiva respecto al proyecto de diseño para la tesis titulada Aplicación de la novela gráfica inspirada en la comunidad Kukama Kukamiria para enriquecer el acervo multicultural de estudiantes de comunicación, diseñado por la Bachiller Rocío Emilia Villacorta Calderón referido a que existe un problema muy complejo y grave que es el desconocimiento de las prácticas culturales de la comunidad Kukama Kukamiria y del mundo selvático, en general.

Por lo tanto, al analizar y revisar el proyecto minuciosamente encuentro que el mismo es actual y de gran relevancia, considerando la poca información que se brinda, las pocas posibilidades de acceder a esta comunidad y la gran oportunidad que se genera para los estudiantes de comunicación al ampliar sus conocimientos y permitirles acceder al mundo de la gráfica con un proyecto cultural de gran alcance; además de contribuir a la integración de nuestra sociedad, respetando y valorando a todos los ciudadanos que en nuestro país habitan.

Atentamente

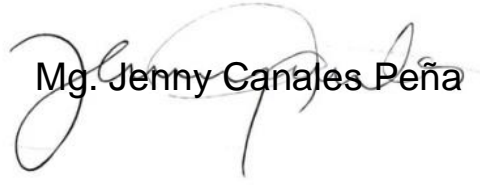




\section{Juicio de pares}

Lima 9 de agosto de 2020

Señores,

Escuela de Posgrado

Universidad San Ignacio de Loyola

Por medio de la presente me dirijo a ustedes a fin de dar una opinión experta respecto al proyecto de diseño para la tesis titulado "Aplicación de la novela gráfica inspirada en la comunidad Kukama Kukamiria para enriquecer el acervo multicultural de estudiantes de comunicación" diseñado por la Bachiller Rocío Emilia Villacorta Calderón, como solución a la problemática acerca del desconocimiento de la realidad(es) de la Selva amazónica

En el proyecto destaca la relevancia de la investigación realizada tanto acerca del estudio del problema, como para realizar la novela, y por lo tanto, la pertinencia de la forma en que propone resolverlo. Además también se destaca la investigación visual, es decir, la investigación requerida para representar fidedignamente los elementos que participan en la ilustración.

Atentamente

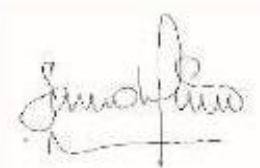

Mg. Sandra Tineo Sanguinetti 


\section{Juicio de pares}

Lima 9 de julio de 2020

Señores,

Escuela de Posgrado

Universidad San Ignacio de Loyola

Por medio de la presente me dirijo a ustedes a fin de poder dar una opinión objetiva respecto al proyecto de diseño para la tesis titulado "Aplicación de la novela gráfica inspirada en la comunidad Kukama Kukamiria para enriquecer el acervo multicultural de estudiantes de comunicación" diseñado por el Bachiller Rocío Emilia Villacorta Calderón referido a que existe un problema muy complejo y grave que es la problemática del desconocimiento de la realidad(es) de la Selva amazónica además de una visión limitada del mundo indígena y su acervo cultural.

Por lo tanto, al analizar y revisar el proyecto minuciosamente encuentro que el mismo es importante, pertinente mediante el uso de la novela gráfica, ya sea por medio impreso o digital para la difusión e importancia cultural de los diferentes pueblos de nuestra Amazonía y su aporte a la pluriculturalidad que nos caracteriza como nación, buscando generar conciencia de las heterogéneas maneras vivir y de ver el mundo. Tener en cuenta el público objetivo al que se dirige y que será artífice de la propagación de la misma es una buena opción al ser futuros profesionales aptos en la propagación de esta información para este proyecto.

En cuanto a la línea gráfica las ilustraciones visualmente atractivas, están bien desarrolladas. Sin embargo, habría que hacer algunos ajustes en la propuesta grafica para que sea más acorde al público objetivo y al formato de publicación elegido. Al ser una novela gráfica, sería bueno agregar elementos que se identifiquen más con este medio, como el uso de viñetas, cartelas o carteleras para las narraciones, bocadillos (espacios en donde se coloca lo que dicen o piensan los personajes), entre otros recursos, igualmente el uso de más planos detalle, medios planos o primeros planos ayudarían mucho. Tal vez una fuente tipográfica menos redonda, y el uso de mayúsculas sería más apropiada para un público más grande, en este caso jóvenes estudiantes. Habría también que ajustar la manera en cómo estéticamente esta tratada la carátula en relación con las páginas interiores, ejecutándolas con la misma personalidad.

Teniendo en cuenta estas observaciones, el proyecto visualmente funcionaría mejor como formato narrativo propuesto para su difusión y función.

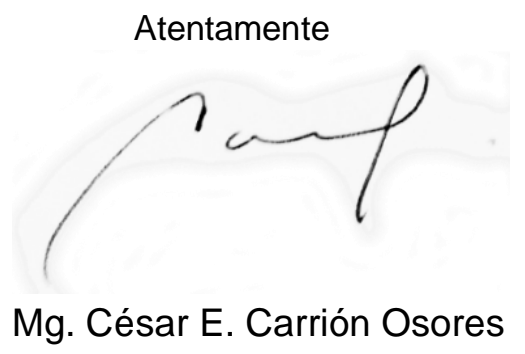


ANEXO 2: ENCUESTA Y RESULTADOS GRÁFICOS 
La presente encuesta es anónima y las respuestas serán utilizadas para el desarrollo de un proyecto de maestría de la carrera de Arte y Diseño Empresarial de la Universidad USIL. Muchas gracias.

\section{Edad: Sexo:}

\section{Centro de estudios:}

\section{Carrera:}

1. ¿Qué sitios de la Amazonía peruana conoces?
a) Chachapoyas.
b) Iquitos.
c) Pucallpa.
d) Moyobamba.
e) Puerto Maldonado.
f) ¿Qué otros lugares de la Amazonía peruana conoces o has visitado?

2. ¿Cuáles de los siguientes personajes o mitos de la Amazonía reconoces?
a) Chullachaqui.
b) La runamula.
c) La tierra sin mal.
d) El bufeo colorado.
e) El dios Kémari.
f) ¿Qué otros personajes conoces?

3. ¿Conoces el significado de Etnia?
a) $\mathrm{Si}$
b) No

4. ¿Cuál de estos conceptos define etnia? Marcar verdadero $(V)$ o falso $(F)$
a) Comunidad humana que comparte un conjunto de rasgos de tipo sociocultural, como cultura, religión, lengua y origen geográfico. ( )
b) Las personas parecidas físicamente en cuanto al color de la piel, la forma del rostro o el tipo del cabello. ( )
c) Las personas de una ciudad específica. ( )

5. ¿Conoces algunas de las etnias peruanas?
a) Si.
b) No.

6. Si tu respuesta fue sí, marca cuáles etnias de la SIERRA reconoces:
a) Los Uros
b) Los Quechuas
c) Los Chopccas
d) Los Huancas
e) Los Aymaras
O nombra alguna etnia específica: 
7. Si tu respuesta fue sí, marca cuáles etnias de la SELVA reconoces:
a) Awajun
b) Candoshi
c) Kukama Kukamiria
d) Huitotos
e) Shipibo-Conibo
O nombra alguna etnia específica:

8. ¿Cómo has conocido estas etnias?
a) Medios de comunicación
b) Turismo
c) Eres descendiente
d) Son parientes de un conocido

Otros:

9. Desde tu punto de vista, a nivel cultural los miembros de las etnias de la Amazonía:
a) Deben ingresar al mundo civilizado para que puedan desarrollarse.
b) Deben ser entendidos como sociedades con características propias y desarrollarse en ese marco.


Resultados gráficos de la encuesta

Gráfico 1: ¿Qué sitios de la Amazonía conoces?

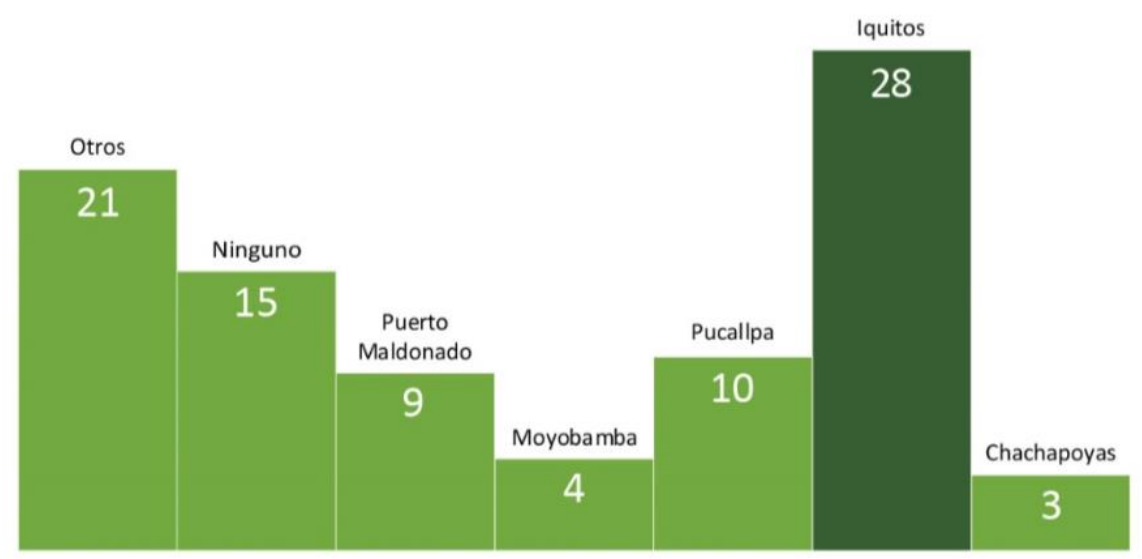

Gráfico 2: Reconocimiento de personajes o mitos de la Amazonía peruana

12 Ninguno

17 Otros

1 Dios Kemarí

13 Bufeo Colorado

2 Tierra sin mal

4 Runamula 
Gráfico 3: ¿Conoces el significado de etnia?

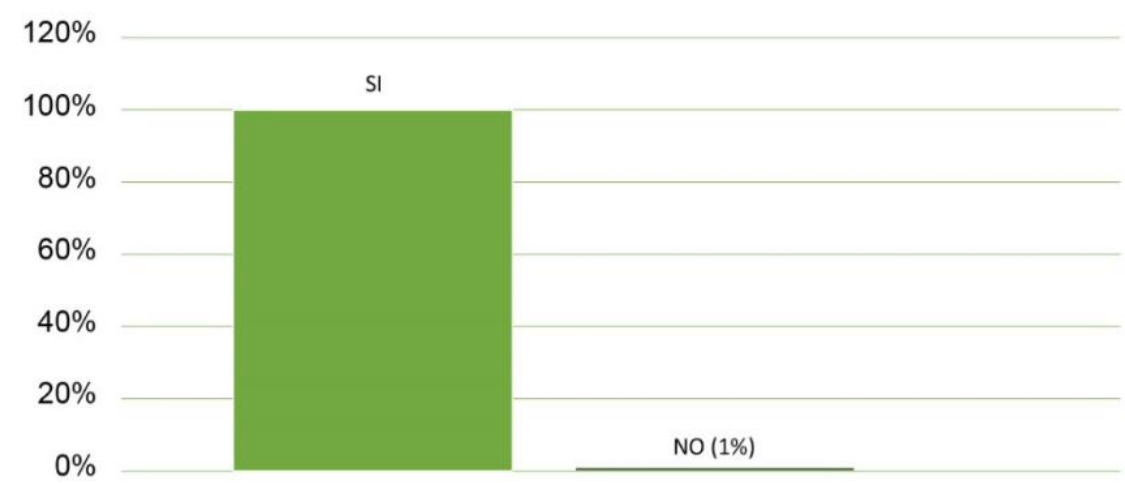

Gráfico 4: ¿Conoces algunas de las etnias peruanas?

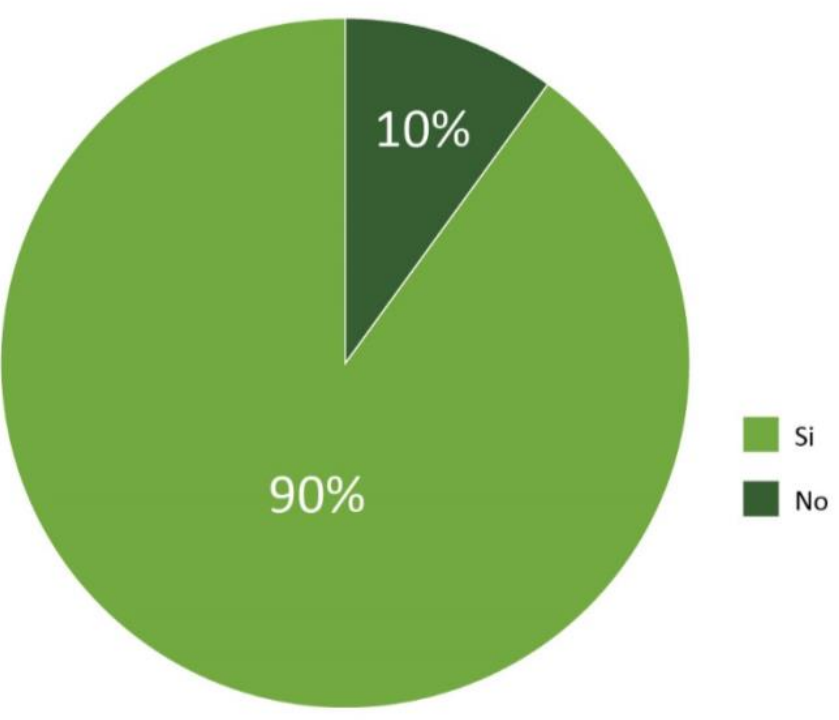


Gráfico 5: Reconocimiento de etnias de la Sierra

6 Otros

7 Ninguna

36 Los Aymaras

15 Los Huancas

5 Los Chopccas

34 Los Quechuas

26 Los Uros

$\begin{array}{lllllllll}0 & 5 & 10 & 15 & 20 & 25 & 30 & 35 & 40\end{array}$

Gráfico 6: Reconocimiento de etnias de la Selva

3 Otros

9 Ninguna

47 Shipibo Conibo

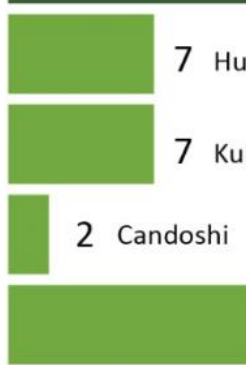

12 Awajun

0

10

20

30

40

50 
ANEXO 3: ENTREVISTAS 


\section{ANEXO 3: Entrevista Sonaly Tuesta Altamirano}

Villacorta: Sobre el tema de identidad y pluriculturalidad, ¿cómo está la situación de la Selva actualmente?

Tuesta: La Selva en el Perú es un tema bastante "clandestino", lo que conocemos de Selva y lo que se habla de Selva es totalmente irreal frente a lo que realmente sucede en las regiones selváticas. El Perú es un país amazónico, tiene más Selva que Sierra, pero es conocido mucho más como un país andino. Creo que hay un desconocimiento de la Selva en si como paisaje, como bosque, como pulmón del mundo y del Perú, pero también hay mucho desconocimiento sobre la diversidad y sobre la gente que vive en esta zona. En el Perú hay muchísimas etnias y solamente nos restringimos a una o dos y, con lo poco que conocemos homogenizamos todo. Es un tema bien complejo, en realidad en la actualidad no hemos avanzado mucho.

\section{Villacorta: ¿Podrías comentarnos un poco sobre esta diversidad? En una encuesta realizada a estudiantes de comunicación se conocieron pocas etnias, los más nombrados fueron los Shipibo- Conibo y los Asháninkas.}

Tuesta: Partamos de esta homogenización que se hace de la Selva, no obstante que todas tienen una manifestación o una expresión específica, sea en el arte, en la forma como realizan sus diseños, en la manera como bailan, como cantan, etc. Casi siempre la gente no se da el trabajo de mirar al detalle esos diseños y todo de alguna manera parece como si fuese parte de una sola cosa, en realidad cada una de estas etnias tiene su propia expresión, no solamente en la lengua, que es muy importante, pero más allá del hecho de comunicarte hablando en una lengua determinada, existe como base también la cosmovisión, la forma de ser y eso hace que finalmente no lleguemos a conectarnos porque no entendemos toda la magnitud que representa una etnia y todo el valor que tiene por sí misma. En el caso de los Kukama, al menos hay grupos de gente preocupada por su propia etnia que ha iniciado el rescate de la lengua y, a partir de eso, que no solo significa hablar en un dialecto específico, se han recuperado otras cosas, cosmovisiones y leyendas, lo que hace que realmente se vea ese grupo, ese pueblo originario, como algo que cohesiona como una población y una comunidad. Sucede eso también en los Yanesha, los Machiguenga (o Matsiguenga) o los Yine Yami, por ejemplo, que tienen cosas aparentemente parecidas entre ellos, pero cada uno tiene la forma de expresión que necesita para poder existir y tener ese contacto con la naturaleza.

Villacorta: ¿Cuáles son los riesgos de que se pierdan estas prácticas culturales distintas? ¿Cómo podemos hacer para apoyar en este aspecto?

Tuesta: En el caso de Perú, desde el poder, yo creo que siempre se ha visto, lamentablemente, la diversidad como un problema; cuando en realidad es el mayor valor que tenemos en nuestro país. Esta diversidad no solo de flora o de fauna, sino sobre todo de culturas, es lo que hace muy especiales y singulares a cada una de ellas, pero al ser tan diverso el trabajo tiene que ser mucho más focalizado y 
serio respecto a cada una, porque es importante cuando se logra valorar a cada uno por sí mismo. Cuando en la calle alguien que no has visto hace tiempo se acuerda de ti con tu nombre, eso te empodera, te hace sentir que para el otro eres importante; eso pasa también en las comunidades. Nosotros hemos intentado llegar a comunidades específicas, a pueblos bastante profundos y alejados donde conozcamos a una etnia determinada y aprendamos de ella a través de su saber artesanal, culinario y su cosmovisión, y nos acerquemos un poco más. Cuando hay conocimiento del otro viene el respeto y el interés. Entonces, desde el poder, si no hay un compromiso con algo para poder desarrollarlo nunca se va a dar. Hay ya un inventario del Ministerio de Cultura respecto a la cantidad de pueblos indígenas y a la población que tienen, es importante ir trabajando con cada uno de ellos, para que sigan manteniendo su tradición. Pero no se trata de conservar una lengua nada más; si nadie habla tu lengua ¿cómo te vas a comunicar?, ¿cómo vas a llegar a una institución si ni siquiera te van a entender? Tiene que hacerse un trabajo que realmente integre y no hablar de una inclusión solamente de discurso.

\section{Villacorta: ¿Consideras que las políticas desarrollistas aún persisten o se ha avanzado al respecto?}

Tuesta: No creo que de forma evidente se hable ahora de "colonizar la selva", pero en realidad las prácticas que se tienen hablan de eso, no necesitan decirlo para darnos cuenta de cómo se piensa en realidad. Hay gente que no hace la consulta previa y se mete a sacar el petróleo o en la mina y cree que el bosque le pertenece y que no es de los habitantes de origen, que esa no es su casa, su territorio. Cuando te acercas a otra población, sea un pueblo originario o no, con una mirada del de fuera, con una mirada de poder, que cree saber más que los que están ahí, eso es un tipo de colonialismo también. Definitivamente, lo que se da ahora es eso.

Ya no se dará como un discurso de "voy a colonizar la selva", pero si hay una práctica que propone que el de fuera sabe más que el que está en la población, en el bosque, y que pertenece a ese pueblo. Cuando uno llega con esa idea de que el desarrollo viene desde la ciudad entonces definitivamente está imponiendo algo y está colonizando o intentando colonizar, sólo que ahora las poblaciones, en muchos casos, han comenzado a reconocerse a sí mismas, a sentirse importantes y que su saber también lo es, y que su cuidado o su forma de relacionarse con el bosque, con su territorio, con su tiempo, con su vida, es valioso, no solo para ellos sino para todo el mundo. Entonces, no se ha hecho un trabajo todavía muy contundente, hay propuestas y proyectos, pero creo que falta todavía incidir en reconocer que la Amazonía es un espacio y un centro muy importante para nosotros, que nos permite una serie de cosas y, por lo mismo, tiene que ser mucho más real esta integración al país.

Villacorta: No han llegado a materializarse por completo las propuestas de tolerancia y respeto para lograr un desarrollo sustentado en la diversidad quizá por la diferencia que siempre ha 
habido entre el pensamiento mítico y la ciencia. ¿Cuál es la importancia de este pensamiento mítico y por qué es necesario promover las leyendas y mitos de las culturas amazónicas?

Tuesta: El saber de las comunidades no disocia de lo que es el saber científico, yo creo que están a la par, entonces hay cosas que realmente parten de ese saber mítico, ese saber de la propia comunidad que ha logrado fortalecerse en el tema científico. Por ejemplo, hace algunos años hablaba con un experto en la quinua que me contaba que alguna vez fue a Puno a un velorio y vio que se hacían unos panecillos (los Quispiños), con quinua negra; le sorprendió porque generalmente se usa otra quinua, y cuando preguntó le dijeron que la quinua negra hacía que uno tuviera menos pena. Cuando se hace el análisis se descubre que esta quinua tiene litio y en realidad sirve para el stress, entonces ese saber natural, de toda la vida, que se ha heredado, es un saber importante, tan valioso como el científico. En la Selva los conocedores, los sabedores, los que curan con Ayahuasca, te dicen que la planta es la que los va orientando sobre cómo tienen que curar, con qué tienen que mezclar, cómo tienen que cantar, cómo tienen que decirle para que cure a una persona; todas esas cosas que hablan de energía, del momento adecuado para relacionarte con determinadas cosas es importante reconocerlas; es algo que está insertado en sus vidas, ellos han vivido toda la vida de esa manera y les ha funcionado. Creo que uno y otro no se separan, creo que si se puede compartir estos dos tipos de saberes y nos podemos entender siempre y cuando ambos sean respetados.

\section{Villacorta: Quizá sea un tema de aceptación y de conocimiento, pues si a alguien de} pensamiento occidental un poblador le ofrece un pan de quinua negra para la tristeza, este tendrá más confianza si se lo indica un doctor. No está la población completamente preparada para aceptar un tipo de pensamiento distinto al que generalmente da la educación tradicional. Tuesta: Claro, yo creo que hay que reconocer que Lima es un centro y los bordes siguen siendo las provincias o todo el país. Ahora sucede también con las capitales de departamentos, que ya se han convertido en otras Limas y se mantienen ajenas a los alrededores, tienen un pensamiento mucho más citadino y más alejado de lo que es el origen. Definitivamente los centros de enseñanza han impartido una visión occidental, alejada un poco de estos mitos, relatos, saberes de la Amazonía o de la Sierra y definitivamente lo que hacen es alejarte más, pero también ahora estamos en una etapa en la que hay una búsqueda de este tipo de conocimiento. Pero es verdad, en las ciudades no hay esa motivación para conocer o para mostrar algún símbolo de algo y a partir de eso buscar que más hay en el país; definitivamente no es parte de un currículo, no es parte de un proyecto, digamos que va a llegar masivamente a todos los estudiantes en este caso. Considero que una propuesta interesante para conocer la Amazonía de hecho que va a despertar, aunque no en todos, algún interés, y el conocimiento que se obtenga de eso va a dar una visión mucho más amplia, que permita un mayor acercamiento. 
Villacorta: En el caso de los estudiantes de comunicación esto es mucho más importante porque en este momento tú y algunas personas más se dedican al tema de la Selva, pero en general, cuando se habla de esta los mismos comunicadores tienen una visión bastante pequeña de la complejidad del tema

Tuesta: Si, muy limitada. Definitivamente muchas de las cosas equivocadas que solemos hacer o proponer tienen mucho que ver con el desconocimiento y el conocimiento tampoco está en mirar de lejos las cosas. Tienes que acercarte, tienes que reconocer. En el colegio, cuando piden un baile de la Selva las chicas están en mini, casi desnudas y siempre bailan lo mismo y tienen unas el diseño Shipibo, otras el Asháninka y otras ni siquiera se entiende que llevan; eso no tiene nada que ver con lo que sucede en la selva, donde las mujeres bailan agarradas en algunas etnias, utilizan una cushma larga, una túnica larga y sus cantos son de otro tipo. Se canta en diferentes momentos, en los momentos rituales, cuando se cura, cuando se come, cuando te juntas con la familia, cuando das la bienvenida. Hay muchísimas cosas interesantes que te permiten no solo reconocer culturalmente a alguien sino reconocer que el otro también es importante y que su casa es el bosque.

Hay gente que se queja de por qué les tenemos que pedir permiso. Cuando vienen a tu casa, te tocan la puerta, no se suben a tu closet y se ponen tu ropa sin tu permiso. Si allá no hay puerta ¿puedes entrar normalmente? No. Hay formas de existir que también se deben aprender.

\section{Villacorta: Algunos aún se avergüenzan o hacen lo que el sistema cree que deben hacer, como} las chicas que bailan aquí en algunos restaurantes, posan en forma "sensual" porque eso es lo esperado. Se muestran aún como espera que se muestre el medio.

Tuesta: Claro, es que a veces el medio te exige; por ejemplo, la gente no habla en su lengua porque simplemente por hacerlo los han rechazado, excluido o no han logrado determinada apertura. Sucedió con el quechua, tu mamá te decía que no hables quechua fuera de tu casa, que no te va a servir de nada, que te van a tratar mal, y lamentablemente en el Perú hasta ahora sigue siendo así en algunos lugares, sobre todo en las ciudades. En este caso hay un prejuicio terrible con la mujer de la Selva; es muy incómodo, cuando yo he dicho que yo soy de Amazonas y hacen comentarios como "huy, caliente"; es un prejuicio gratis. Lo que vas a encontrar es gente espontánea en muchos lugares, pero eso no significa más que eso, que es espontánea y que finalmente eso es parte de su idiosincrasia. Esta chica que conociste, al estar en un entorno como este y tener que ganar algo, de hecho, que va a seguir el prejuicio y se va a mostrar como la quieren mirar. Y Jessica y Olinda, que son reconocidas por ser embajadoras de sus etnias definitivamente tienen un conocimiento mayor de su cultura y así como realmente ellas son se han presentado ante el mundo y las han aceptado. Olinda es una maestra artesana shipiba y Jessica es una cantante y es embajadora de los Asháninkas. 
Villacorta: Claro y no la pasaron fácil tampoco, aunque ahora son reconocidas. Cuando Olinda llegó al lugar donde le tomé las fotos, yo tuve que salir para que la dejen ingresar. Pensé que posiblemente hubo discriminación porque viste su ropa tradicional; ella estaba en una lista de ingreso y debía haber entrado ni bien se presentó, se vista como se vista.

Tuesta: Ese es un gran tema, yo he estado alguna vez caminando en la calle con Sonia, una amiga de Capachica, que viste su traje tradicional, que es su pollera, un traje muy lindo, y le han preguntado donde va a bailar; o cuando yo me he puesto un poncho cusqueño tradicional me han preguntado si soy del Cusco o a que actuación voy. Hay bastante prejuicio.

En realidad, somos una sociedad hipócrita. Por ejemplo, como estamos ahora conociendo y reconociendo nuestra gastronomía, y se encumbra con orgullo para el país. Pero en lo cotidiano ninguneamos a alguien porque come cuy: "oye serrano anda come tu cuy"; entonces se convierte en un insulto. En el caso de la selva también hay mucho prejuicio.

Villacorta: Específicamente en el caso de los Kukama, son un grupo pesquero. ¿Cómo su cosmovisión se ve influida por esta realidad que ellos viven diariamente? ¿Qué relación hay entre su mitología, su cosmovisión y su realidad y que otros ejemplos sobre la relación cosmovisión-vida cotidiana podrías citar?

Tuesta: Son gente del río. Yo he conocido a los Kukama en Nauta, en Loreto, un grupo diverso que está ahora en proceso de recuperar su lengua y la gente misma está reaprendiendo, parece que esta extirpación, esta anulación de su lengua fue tan fuerte que la gente está comenzando a aprender otra vez a hablar, ya la están enseñando en los colegios y definitivamente eso les da una visión más consistente de lo que son. Yo los he conocido como artesanos de la chambira, para cuyo uso hay toda una ritualidad. Todos estos mitos de origen, estas leyendas que existen respecto a los animales y a las plantas tienen que ver con su propio entorno (por ejemplo, para ellos el río tiene que ver con lo cotidiano); recuperar la lengua es recuperar también ese entorno que tienen y que ha sido suyo de toda la vida. Sucede eso en otras etnias también, por ejemplo en el caso de los Shipibos, donde las depositarias de la tradición son las mujeres, del Kené, de este diseño que realizan a lo largo de los años; por ejemplo, se dice que las mujeres escogidas para definir estos diseños tienen mayor shinan (imaginación), mayor sueño, quizá porque a ellas desde muy pequeñas les echan el piri piri en el ojo para que puedan mirar mejor, mirar más allá de lo que suele ver cada persona y así crear esos diseños que aparecen en su mente y transmitirlos a las demás. Esto no es una creación literaria, es una realidad; el hecho que en la ciudad hayamos perdido toda esta creencia, esta magia, no significa que no la vivamos tan cercanamente como se vive en los pueblos originarios.

Villacorta: Actualmente los Kukama Kukamiria y otras etnias están luchando para que se legitimen sus tierras porque algunos viven y han vivido años dentro de lo que se considera zona 
protegida. ¿Cómo crees que se podría lograr un consenso para que ellos tengan sus tierras y también la preservación de esta zona como tierra protegida?

Tuesta: $\mathrm{Si}$, las tierras quedaron protegidas y luego se volvieron intangibles porque ellos vivían ahí, porque finalmente las cuidaron. De hecho, en muchos casos como en con los Ese Eja (Madre de Dios) se ha llegado a entender que eso también es importante, siendo reconocidos ellos como guardianes de la naturaleza y del bosque. Siempre tiene que haber un previo reconocimiento, es decir: "nosotros, gracias a ustedes tenemos esta diversidad que queremos proteger con declarar una zona intangible, pero ustedes tienen la posibilidad de estar en esta zona y poder desarrollarse". Y que haya posibilidad de que los proyectos también los involucren. No vas a hacer una zona intangible y dejarlos fuera. Hay proyectos interesantes, pero hay que hacer que sean realmente sostenibles; la gente tiene derecho a hacer que ese territorio que han conservado sea suyo y no esté expuesto para que en cualquier momento pueda ser arrancado y finalmente ellos puedan ser fácilmente expulsados. Creo que es importante pero lo más fuerte es este consenso que se está desarrollando en algunos casos.

Aparentemente es bastante contradictorio, estas poblaciones han vivido ahí siempre. Finalmente, el hecho de que estén conservadas en algunos casos se los debemos a ellos, los pueblos originarios; definitivamente se tiene que reconocer a las poblaciones como guardianes del bosque o de estas zonas y que a la par que sean declaradas intangibles, sus pobladores puedan ser revalorizados como personas valiosas en este trabajo de protección y que también tengan la posibilidad de poder desarrollar lo que saben. Hay gente que tiene saberes medicinales, agrícolas, artesanales; y es importante que lo puedan desarrollar en una mejor condición para poder salir adelante, que posteriormente sus hijos puedan tener una profesión que les permita, con otro tipo de conocimiento, volver a su lugar de origen y desarrollar mejor esta protección que tanto necesitan esas zonas; ya se está dando en algunos lugares y creo que es importante seguir reconociendo, pero no imponer; el desarrollo o los tipos de desarrollo dependen de donde estamos y hay que reconocer qué cosa es para ellos el desarrollo.

\section{Villacorta: Con respecto a los jóvenes: ¿cuáles serían las ventajas de que los estudiantes de} Comunicación cuenten con un sólido conocimiento de nuestras distintas realidades?

Tuesta: Eso es lo que tiene que suceder. Un comunicador en este país tan diverso, multicultural, de distintas realidades, un país fragmentado, de centros, de bordes, con un tipo de desarrollo en una zona y otros tipos de desarrollos que si no nos acercamos a ellos no los vamos a conocer, tiene que estar inmerso en eso, sino su capacidad crítica, de análisis, de registro es muy limitada. En esta época en que estamos viendo mucha información, creo que te debe distinguir una información especializada, focalizada y bastante específica, entonces al conocer más de nuestro país, de las etnias amazónicas, de que somos un país amazónico, te va a dar otra mirada. Así, concretamente en los proyectos que se puedan desarrollar se va a ser mucho más paciente, cuidadoso, y se van a poder realizar cosas que 
realmente favorezcan a alguien. No es necesario que este beneficio sea masivo, sino que si beneficiamos a alguien específico con un proyecto sostenible creo que hacemos suficiente.

\section{Entrevista Carlos Rivadeneyra Olcese \\ Responsable de Grados y Títulos y Coordinador del Área de Comunicación para el Desarrollo de la Universidad de Lima}

\section{Villacorta: ¿Cuál es el perfil del comunicador de la Universidad de Lima en el momento en el que ingresan, que conocimientos tienen con respecto a la pluriculturalidad peruana?}

Rivadeneyra: Los estudiantes de comunicación han ido cambiando. En la década de los 80 y los 90 había una presencia de estudiantes de clase media y clase media alta, sin embargo, a partir del año 2000 en adelante me da la impresión que el porcentaje de estudiantes de clase media alta se ha reducido, el de clase media ha aumentado, pero se ha incrementado también el de clase media baja. Lo que significa una mayor cantidad de estudiantes, pero también más diversa.

Eso va en correlato al perfil de la economía en el país; en los años 2000 esta mejoró, creció y resucitó la clase media y nuevamente esta ve a la educación como un mecanismo de mejora y aparecen más estudiantes en las universidades públicas y privadas.

A pesar de ese cambio el conocimiento acerca de la diversidad cultural, de la pluriculturalidad peruana es bastante escaso. ¿Por qué hago mención de este cambio de características socioeconómicas en el estudiante de comunicación de la Universidad de Lima? Hay que tomar en cuenta que los que vivimos en Lima somos en gran mayoría hijos o nietos de migrantes provincianos. Y los migrantes también tienen raíces indígenas en algunos de los casos. Entonces, creo que hay una menor lejanía de los estudiantes con la diversidad peruana. Antes, si bien había una lejanía porque no había comunidades de estudiantes de provincias o con vínculo con comunidades indígenas, sí había un interés en conocer. Ahora no sé si el interés permanezca igual o ha descendido, pero sí hay una mayor cercanía, porque vienen chicos de diferentes partes de Lima, como Pucallpa, Ayacucho, Cuzco, Piura, Chiclayo, Trujillo, Cajamarca, Arequipa; de alguna manera tienen una mirada mayor del país y a pesar de que no vengan directamente de las comunidades indígenas saben de la existencia de ellas.

Sin embargo, el común denominador es un alejamiento de las comunidades y del conocimiento de las comunidades indígenas. Y eso no es gratuito; es parte de la formación social de las familias en nuestro país. Los estudiantes de la universidad son básicamente hijos de familias urbanas, que ven al mundo 
rural como un mundo extraño, diferente, como un mundo en el cual hay que capturar la foto de visita turística. Por otro lado, también se debe a la deficiente formación en la escuela, que no nos acerca ni por asomo a la diversidad cultural del país; con esa deficiencia llegan a la Universidad, y esta tampoco enfoca ese tema como uno principal para la formación, sino como uno más.

\section{Villacorta: ¿Qué cursos de la malla de comunicación ayudan a fortalecer esta visión integral que debería tener el comunicador en su formación?}

Rivadeneyra: El curso de Sociedad y Comunicación. Además, desde 2019 tenemos el curso obligatorio común Comunicación y Desarrollo, que ve la cuestión étnica de la problemática indígena como uno de los temas de las 14 semanas de este curso; a mi criterio, la "cuestión indígena", como lo dijo Mariátegui, es un tema importante en un país tan diverso que busca ser plural, cuando creo que eso es un caro anhelo.

En los cursos de Comunicación y Desarrollo hemos puesto, de manera ex profesa y, además, intentamos provocadora, el curso Medios Offline y Desarrollo. Pensamos que estamos en la era digital y que todos están vinculados, linkeados, y eso es una falacia; este curso es para pensar la comunicación para estos grupos sociales que no están integrados digitalmente, que tienen diferentes problemáticas y con los cuales hay que trabajar con medios adecuados. No podemos hacer una campaña en Facebook con poblaciones rurales yaneshablantes cuando no vamos a llegar a ellos así.

Además, [en Estudios Generales] está el curso de Globalización y Realidad Nacional, que muestra la problemática social del país. En general me parece que las Facultades de Comunicación, incluyendo la Universidad de Lima, tienen una falencia con respecto a la comunicación indígena. En la Universidad Javeriana (Colombia) llevan Comunicación Comunitaria en dos semestres, y en uno de ellos se enfocan en poblaciones indígenas. Acá tenemos raíces indígenas mucho más profundas, numerosas y, por tanto, importantes; sin embargo, nuestra malla es débil en abordar esos temas.

Por otro lado, hacer comunicación con estos grupos es bien complejo y complicado. El expertise, la posibilidad de lectura antropológica de los comunicadores para acercarnos a los pobladores indígenas es muy limitado; las comunidades son muy complejas y manejan códigos muy distintos a los que manejamos los profesionales de Lima; ahí hay una enorme barrera.

\section{Villacorta: ¿Qué políticas considera la Universidad para fortalecer la visión de la identidad?}

Rivadeneyra: Muchas veces cuando hablamos de política nos referimos a algo establecido y no hay eso. En los cursos de desarrollo hay una costumbre de hacer visitas de campo fuera de Lima. Hemos ido a Tarapoto, Yurimaguas, Pucallpa, Ayacucho; por lo menos uno de los días hemos estado en contacto con instituciones o comunidades indígenas. Pasar medio día con ellos, sentarnos a conversar, 
compartir un agua, un masato; esa sola y modestísima experiencia para los estudiantes que pueden viajar hace que los chicos se sientan sumamente gratificados, descubren un país u "otros países" dentro de Perú, porque son realidades sociales, culturales, muy diferentes a lo que ellos conocen. Esta visita no es con afán turístico, se trata de acercarnos, sentarnos, como iguales a conversar, a compartir un rato, ni siquiera a entrevistar.

Experiencias de esta naturaleza fortalecen al estudiante, no es algo establecido en la malla, es una actividad extra que hacen los cursos de desarrollo; sí creemos que debemos fortalecerla. Asimismo, entiendo que en los cursos de Problemática Nacional y Sociedad y Desarrollo tratan el tema de las identidades, pero desde una mirada mucho más amplia, porque contemplan también a las comunidades urbanas, lo cual es totalmente válido.

Ahora, acercarnos al mundo indígena (por ende, al mundo rural) es un gran esfuerzo para una universidad como la nuestra y en general para las Facultades de Comunicación. Hay que considerar otra variable con respecto a la formación de los comunicadores. Por lo menos en los últimos 20 años las Facultades de Comunicación han estado muy cercanas a la alta tecnología; el esfuerzo en inversión en mejorar la carrera es tener más computadoras, mejores pantallas y softwares, es decir, conocer más la informática y la cibernética que la comunicación social. Considero que eso pasa en muchas facultades y lo veo como un proceso de maduración de las de comunicación.

Retomando lo de los cursos, hay algunos temas dentro del sílabo en Comunicación y Desarrollo, algunos casos que trabajamos en el curso Creatividad para el Desarrollo, pero algo que considere la Selva como una cuestión temática exclusiva, no.

\section{¿Sobre la especialidad de Comunicación para el Desarrollo tienes porcentajes de cuántos alumnos optan por ella?}

Aproximadamente el 10\%. Estamos trabajando para que esto se duplique, no es fácil porque es una de las especialidades en constante evolución política, social, cultural. Estamos en un país que en los últimos años ha cambiado bastante, no siempre para bien. Los retos del desarrollo son diferentes, muchas de las políticas estatales en favor del desarrollo se han quedado solo en el asistencialismo. La comunicación para el desarrollo no tiene un espacio ganado en la institucionalidad estatal, como el periodista, el relacionista público, el comunicador audiovisual o el publicista. El comunicador corporativo no está en la estructura del estado y menos el comunicador para el desarrollo.

\section{¿En cuanto a las investigaciones para titularse con temáticas en el área de desarrollo cuál es el porcentaje de trabajos?}


Aproximadamente el 2\% en todas las modalidades. Aunque hay un mayor porcentaje de tesis en el área de comunicación para el desarrollo, es un número bajo porque las tesis presentadas son pocas. En general, los temas que se tocan más son los orientados a la publicidad y a la comunicación corporativa.

\section{¿Cómo ves al final, a punto de licenciarse, en cuanto al conocimiento de su realidad?}

Creo que el conocimiento general del país sigue siendo escaso, débil, pero sí han logrado conocer el tema con el cual se titulan, con buena profundidad; lo manejan bastante bien. Si ese tema está vinculado con una comunidad rural, indígena, nativa, excelente, pero no todos se titulan así. La Universidad ayuda bastante en la formación profesional, no podemos subsanar cosas que vienen de antes. Soy crítico en el sentido de que hay familias que ven lo rural o indígena como una foto postal, así que por más que la escuela le asigne un espacio al tema, sigue siendo lo indígena una foto postal en el Facebook. No hay una preocupación, interés por esto. Perú es un país que tiene un gran legado arqueológico, pero el peruano está acostumbrado a visitar la ruina; para nosotros el resto arqueológico es la ruina, la piedra, el barro, pero poco pensamos en quiénes, cómo o por qué lo hicieron, y si los antiguos siguen presentes o no. Nos fascina la selva, el colorido, el verde, la fauna, pero hay gente ahí. ¿Cómo viven estos pobladores peruanos, cuán peruanos se sienten, qué tienen para enseñarnos? Ese es un gran esfuerzo de darle vuelta a la rosca y ver que el patrimonio cultural no es solamente lo material sino también lo inmaterial, donde hay una gran riqueza.

Nuestro país siempre ha visto al Océano Pacífico. Un país quiere mirar los valles y el desierto, pero el OP (Ocean Pacific). El gran muro del país son los Andes; hasta ahí llegamos. Detrás de este está el gran jardín amazónico. De cuando en vez lo visitamos. Y nos hemos olvidado de ese país. Allí hay muchas nacionalidades, etnias, lenguas, costumbres, muchísima riqueza. Nos hemos acordado de la riqueza material que da el petróleo, talar los árboles, el oro. Pero conocemos poco esa riqueza cultural y menos la aprovechamos. 